NBER WORKING PAPER SERIES

\title{
ESTIMATING THE INTERTEMPORAL RISK-RETURN TRADEOFF USING THE IMPLIED COST OF CAPITAL
}

\author{
Lubos Pastor \\ Meenakshi Sinha \\ Bhaskaran Swaminthan \\ Working Paper 11941 \\ http://www.nber.org/papers/w11941
NATIONAL BUREAU OF ECONOMIC RESEARCH
1050 Massachusetts Avenue
Cambridge, MA 02138
January 2006

\begin{abstract}
Pastor is Professor of Finance at the Graduate School of Business at the University of Chicago, Faculty Research Fellow at the NBER, and Research Affiliate at the CEPR. Sinha is Research Associate at Cornerstone Research. Swaminathan is Director of Research at LSV Asset Management and Professor of Finance at the Johnson Graduate School of Management at Cornell University. Email: lubos.pastor@ChicagoGSB.edu,.ms233@cornell.edu, bswamina@johnson.cornell.edu. Helpful comments were gratefully received from George Constantinides, Doug Diamond, Gene Fama, Toby Moskowitz, Rob Stambaugh, Pietro Veronesi, Robert Whitelaw, Franco Wong, and the audiences at the University of Chicago and at the 2005 meetings of the Western Finance Association. The views expressed herein are those of the author(s) and do not necessarily reflect the views of the National Bureau of Economic Research.
\end{abstract}

(O2006 by Lubos Pastor, Meenakshi Sinha, and Bhaskaran Swaminathan. All rights reserved. Short sections of text, not to exceed two paragraphs, may be quoted without explicit permission provided that full credit, including $(\odot$ notice, is given to the source. 
Estimating the Intertemporal Risk-Return Tradeoff Using the Implied Cost of Capital Lubos Pastor, Meenakshi Sinha, and Bhaskaran Swaminathan

NBER Working Paper No. 11941

January 2006

JEL No. G1

\section{ABSTRACT}

We reexamine the time-series relation between the conditional mean and variance of stock market returns. To proxy for the conditional mean return, we use the implied cost of capital, computed using analyst forecasts. The usefulness of this proxy is shown in simulations. In empirical analysis, we construct the time series of the implied cost of capital for the G-7 countries. We find strong support for a positive intertemporal mean-variance relation at both the country level and the world market level. Some of our evidence is consistent with international integration of the G-7 financial markets.

Lubos Pastor

Graduate School of Business

University of Chicago

5807 South Woodlawn Ave

Chicago, IL 60637

and NBER

lubos.pastor@chicagogsb.edu

Meenakshi Sinha

Cornerstone Research

msinha@cornerstone.com

Bhaskaran Swaminathan

Cornell University

bswamina@johnson.cornell.edu 


\section{Introduction}

The tradeoff between risk and return is a central concept in finance. Finance theory generally predicts a positive risk-return relation, both across assets and over time. For example, the intertemporal capital asset pricing model of Merton (1973) predicts a positive timeseries relation between the conditional mean and variance of market returns. However, the empirical evidence on the sign of the intertemporal risk-return relation is inconclusive. ${ }^{1}$

To explain the mixed nature of the evidence, some researchers have shown that the intertemporal mean-variance relation need not be positive theoretically (e.g., Abel (1988), Backus and Gregory (1993), and Whitelaw (2000)). Others have argued that a positive mean-variance relation emerges when the empirical specification includes hedging demands (e.g., Scruggs (1998) and Guo and Whitelaw (2005)). Yet others argue that the relation is highly sensitive to the way conditional variance is measured (e.g., Harvey (2001), Wang (2004), and Ghysels, Santa-Clara, and Valkanov (2005)). For example, Ghysels et al. state that "the main difficulty in testing the ICAPM relation is that the conditional variance of the market is not observable," and that "the conflicting findings of the above studies are mostly due to differences in the approach to modeling the conditional variance."

While estimating the conditional variance of market returns is clearly important, to us, estimating the conditional mean return seems no less important. First moments of returns are generally more difficult to estimate than second moments (Merton (1980)). The conditional mean return is sometimes estimated by projecting future returns onto a set of conditioning variables. ${ }^{2}$ The results produced by this approach tend to be sensitive to the choice of the conditioning variables (Harvey, 2001). Another popular estimate of the conditional mean return in this literature is the realized future return. ${ }^{3}$ Although realized returns provide unbiased estimates of expected returns, they are notoriously noisy. For example, Elton (1999) argues that "realized returns are a very poor measure of expected returns." Lundblad (2005) shows that when realized returns proxy for expected returns, a very long sample is needed to detect a positive risk-return relation in simulations.

\footnotetext{
${ }^{1}$ Some studies find a positive relation (e.g., Scruggs (1998), Ghysels, Santa-Clara, and Valkanov (2005), Lundblad (2005)), but others find a negative relation (e.g., Campbell (1987), Turner, Startz, and Nelson (1989), Glosten, Jagannathan, and Runkle (1993), Harvey (2001), Lettau and Ludvigson (2003), Brandt and Kang (2004)), and yet others find either no significant relation or mixed evidence (e.g., French, Schwert, and Stambaugh (1987), Baillie and DeGennaro (1990), Nelson (1991), Campbell and Hentschel (1992), Chan, Karolyi, and Stulz (1992), Whitelaw $(1994,2000)$ ).

${ }^{2}$ See, for example, Campbell (1987), Harvey (2001), Whitelaw (1994), and Lettau and Ludvigson (2003).

${ }^{3}$ See, for example, French, Schwert, and Stambaugh (1987), Baillie and DeGennaro (1990), Nelson (1991), Chan, Karolyi, and Stulz (1992), Glosten, Jagannathan, and Runkle (1993), De Santis and Imrohologlu (1997), Scruggs (1998), Ghysels, Santa-Clara, and Valkanov (2005), and Lundblad (2005).
} 
This paper reexamines the conditional mean-variance relation using a different proxy for the conditional expected return: the implied cost of capital. The implied cost of capital for a given asset is the discount rate (or internal rate of return) that equates the asset's market value to the present value of all expected future cash flows. One appealing feature of this proxy is that it does not rely on realized asset returns. Estimating expected return using the implied cost of capital is increasingly popular in the finance literature. For example, Friend, Westerfield, and Granito (1978), Kaplan and Ruback (1995), Gebhardt, Lee, and Swaminathan (2001), Brav, Lehavy, and Michaely (2003), and Lee, Ng, and Swaminathan (2003) compute the implied costs of capital for a cross section of firms. Claus and Thomas (2001) and Fama and French (2002) use similar approaches to estimate the expected return for the market portfolio. To our knowledge, the implied cost of capital has not yet been used to analyze the relation between the conditional mean and variance of stock returns.

We begin by deriving some general analytical results about the implied cost of capital. We show that if dividend growth follows an $\mathrm{AR}(1)$ process, the implied cost of capital is a linear function of the dividend yield and dividend growth. If, in addition, the conditional expected return also follows an $\mathrm{AR}(1)$ process, then the implied cost of capital is perfectly correlated with the conditional expected return over time. Therefore, the implied cost of capital should be useful in capturing time variation in expected returns.

We conduct simulations to analyze the usefulness of the implied cost of capital in estimating the intertemporal risk-return tradeoff. First, we design a simple framework in which the conditional mean and variance of stock returns are positively related. We simulate the time series of the conditional moments and compare the ability of various proxies for the conditional mean to detect the positive mean-variance relation. We show that the relation is much easier to detect using the implied cost of capital than using realized returns.

Importantly, the implied cost of capital outperforms realized returns even in the absence of information about dividend growth. In that case, the implied cost of capital is perfectly correlated with the dividend-price ratio, so its changes are driven mostly by changes in the stock price: increases in the stock price are accompanied by declines in the implied cost of capital, and vice versa. Therefore, the ability of the implied cost of capital to detect a positive mean-variance relation in that case stems from the fact that price changes tend to be accompanied by variance changes in the opposite direction. As long as price changes are to some extent driven by changes in expected returns, the implied cost of capital should be positively related to the conditional variance. In line with this intuition, we find that the correlation between the implied cost of capital and the conditional variance is high especially 
when market returns are driven mostly by changes in expected returns (as opposed to changes in expected cash flows). However, the implied cost of capital outperforms realized returns also when only a small fraction of the market return variance is due to time-varying expected returns. In short, the implied cost of capital seems well suited for capturing the risk-return tradeoff, even in the absence of information about future cash flow.

In our empirical analysis, we estimate the intertemporal relation between the conditional mean and variance of excess market returns in the G-7 countries. We construct monthly estimates of the conditional mean and variance in 1981-2002 (for the United States) and 1990-2002 (for Canada, France, Germany, Italy, Japan, and U.K.). To proxy for the conditional mean return, we compute the implied cost of capital, following the approach developed by Gebhardt, Lee, and Swaminathan (2001) and Lee, Ng, and Swaminathan (2003). For each firm in each month, we compute the implied cost of capital using analyst forecasts of earnings and historical plowback rates. We then aggregate these cost of capital estimates across firms to compute a market-wide implied cost of capital for each country. We compute both equaland value-weighted versions of the country-level implied cost of capital. Finally, we subtract the long-term local government bond yield from the implied cost of capital to compute the implied risk premium for each country. This implied risk premium is the measure of the conditional mean return that we use in our regression tests.

To estimate the conditional variance of market returns for a given country in a given month, we average squared daily market returns over the previous month. This approach to variance estimation is simpler than some other approaches developed in the literature. ${ }^{4}$ Although we believe that it is important to estimate the conditional variance as precisely as possible, we choose a simple variance estimator to highlight the paper's focus on estimating the conditional expected return.

Our empirical results provide strong support for a positive relation between the conditional mean and variance of market returns. Consider the equal-weighted average implied risk premium as a proxy for expected excess market return at the country level. We find a positive relation between the levels of the implied risk premia and volatility in all G-7 countries, and this relation is statistically significant for five of the seven countries. We also find a positive and statistically significant relation between shocks to the risk premia and shocks to volatility in Canada, France, Germany, U.K., and U.S. The evidence based on the value-weighted average implied risk premium is somewhat weaker but still generally

\footnotetext{
${ }^{4}$ Our estimator coresponds to the simplest variance estimator considered by French, Schwert, and Stambaugh (1987). Andersen, Bollerslev, Diebold, and Labys (2003) discuss the advantages of realized volatility relative to $\mathrm{ARCH}$, stochastic volatility, and other parametric volatility models.
} 
supportive of a positive mean-variance relation. We find a positive and significant relation between the levels of the implied risk premia and volatility in four of the seven countries. The relation between the shocks to the premia and to volatility is positive and significant for three countries (France, U.K., and U.S.). The results are similar whether we use conditional variance or standard deviation to measure volatility.

We also find a positive intertemporal risk-return tradeoff at the global level. There is a strong positive relation between the world market volatility and the world market implied risk premium, approximated by averaging the implied risk premia across the G-7 countries. There is also a positive relation between several individual country risk premia and the world market volatility. Finally, some country risk premia are positively related to the conditional covariances of the country returns with the world market portfolio. This evidence is consistent with some international integration of the G-7 financial markets.

It is noteworthy that we find any statistically significant relations at all, given the short length of our samples (22 years for the U.S., and 13 years for the other six countries) and the fact that we estimate the conditional variance in a simple manner. The implied cost of capital seems quite powerful in capturing time variation in expected returns.

As one way of assessing the robustness of our results, we estimate return volatility using the implied volatility from the options market, which is available to us for the U.S. stock market. The results based on implied volatility are even stronger than those based on realized volatility. The mean-variance relation is significantly positive with the $t$-statistics on the order of ten in a 17-year-long sample. Additional tests show that the mean-variance relation remains positive after controlling for hedging demands, and that this relation is not driven by analyst forecast errors. The mean-variance relation weakens but remains mostly positive when we replace the implied cost of capital by the dividend yield.

While our results based on the implied cost of capital indicate positive risk-return tradeoffs at various levels, the tests that use realized returns to proxy for expected returns find no significant tradeoffs. These results confirm our simulation evidence, and reinforce the notion that realized returns are a poor proxy for expected returns.

The paper is organized as follows. Section 2 characterizes the implied cost of capital analytically. Section 3 provides simulation evidence on the usefulness of the implied cost of capital in estimating the risk-return tradeoff. Section 4 describes our data and empirical methodology. Section 5 discusses the empirical results. Section 6 concludes. 


\section{Implied Cost of Capital}

The implied cost of equity capital is the discount rate that equates the present value of expected future dividends to the current stock price. One common approach is to define the implied cost of capital as the value of $r_{e}$ that solves

$$
P_{t}=\sum_{k=1}^{\infty} \frac{E_{t}\left(D_{t+k}\right)}{\left(1+r_{e}\right)^{k}}
$$

where $P_{t}$ is the stock price and $D_{t}$ are the dividends paid at time $t$. To obtain some analytical results about the implied cost of capital under time-varying expected returns, we propose a slightly different but analogous definition. Campbell and Shiller (1988) develop a useful approximation to the present value formula, which expresses the log price $p_{t}=\log \left(P_{t}\right)$ as

$$
p_{t}=\frac{k}{1-\rho}+(1-\rho) E_{t} \sum_{j=0}^{\infty} \rho^{j} d_{t+1+j}-E_{t} \sum_{j=0}^{\infty} \rho^{j} r_{t+1+j}
$$

where $r_{t}$ is the $\log$ stock return, $d_{t} \equiv \log \left(D_{t}\right), \rho=1 /(1+\exp (\overline{d-p})), k=-\log (\rho)-(1-$ $\rho) \log (1 / \rho-1)$, and $\overline{d-p}$ is the average $\log$ dividend-price ratio. In this framework, it is natural to define the implied cost of capital as the value of $r_{e, t}$ that solves

$$
p_{t}=\frac{k}{1-\rho}+(1-\rho) \sum_{j=0}^{\infty} \rho^{j} E_{t}\left(d_{t+1+j}\right)-\sum_{j=0}^{\infty} \rho^{j} r_{e, t}
$$

To provide some insight into the implied cost of capital, it is convenient to assume that $\log$ dividend growth $g_{t+1} \equiv d_{t+1}-d_{t}$ follows a stationary $\operatorname{AR}(1)$ process:

$$
g_{t+1}=\gamma+\delta g_{t}+v_{t+1}, \quad 0<\delta<1, \quad v_{t+1} \sim N\left(0, \sigma_{v}^{2}\right)
$$

Given these dynamics of $g_{t}$, the Appendix shows that

$$
\sum_{j=0}^{\infty} \rho^{j} E_{t}\left(d_{t+1+j}\right)=\frac{d_{t}}{1-\rho}+\frac{\gamma}{(1-\delta)(1-\rho)^{2}}-\frac{\gamma \delta}{(1-\delta)(1-\rho)(1-\rho \delta)}+\frac{\delta g_{t}}{(1-\rho)(1-\rho \delta)}
$$

Substituting this equation into equation (3), we obtain

$$
p_{t}=\frac{k}{1-\rho}+d_{t}+\frac{\gamma}{(1-\delta)(1-\rho)}-\frac{\gamma \delta}{(1-\delta)(1-\rho \delta)}+g_{t} \frac{\delta}{1-\rho \delta}-\frac{r_{e, t}}{1-\rho},
$$

which can be rearranged into

$$
r_{e, t}=k+\frac{\gamma}{1-\delta}+\left(d_{t}-p_{t}\right)(1-\rho)+\left(g_{t}-\frac{\gamma}{1-\delta}\right) \frac{\delta(1-\rho)}{1-\rho \delta} .
$$


The implied cost of capital, $r_{e, t}$, is a simple linear function of the log dividend-price ratio, $d_{t}-p_{t}$, and $\log$ dividend growth, $g_{t}$. (Note some similarity with the well known constantparameter Gordon growth model, in which $P=D /(r-g)$, and thus $r=D / P+g$.)

Further insight into the implied cost of capital can be obtained by assuming that the conditional expected return, $\mu_{t} \equiv E_{t}\left(r_{t+1}\right)$, follows a stationary $\mathrm{AR}(1)$ process:

$$
\mu_{t+1}=\alpha+\beta \mu_{t}+u_{t+1}, \quad 0<\beta<1, \quad u_{t+1} \sim N\left(0, \sigma_{u}^{2}\right)
$$

Under this assumption, the Appendix shows that

$$
\sum_{j=0}^{\infty} \rho^{j} E_{t}\left(r_{t+1+j}\right)=\frac{\alpha}{(1-\beta)(1-\rho)}+\left(\mu_{t}-\frac{\alpha}{1-\beta}\right) \frac{1}{1-\rho \beta} .
$$

Plugging equations (5) and (9) into equation (2), we obtain

$$
\begin{aligned}
p_{t}= & \frac{k}{1-\rho}+\frac{\gamma}{(1-\delta)(1-\rho)}-\frac{\alpha}{(1-\beta)(1-\rho)} \\
& +d_{t}+\left(g_{t}-\frac{\gamma}{1-\delta}\right) \frac{\delta}{(1-\rho \delta)}-\left(\mu_{t}-\frac{\alpha}{1-\beta}\right) \frac{1}{1-\rho \beta} .
\end{aligned}
$$

The log stock price $p_{t}$ is a simple function of $d_{t}, g_{t}$, and $\mu_{t}$. The stock price increases with dividends $d_{t}$ and dividend growth $g_{t}$, and it decreases with expected return $\mu_{t}$. Note that $p_{t}$ depends on the deviations of $\mu_{t}$ and $g_{t}$ from their unconditional means of $\alpha /(1-\beta)$ and $\gamma /(1-\delta)$, respectively. Comparing equations (10) and (7), we have

$$
r_{e, t}=\frac{\alpha}{1-\beta}+\left(\mu_{t}-\frac{\alpha}{1-\beta}\right) \frac{1-\rho}{1-\rho \beta},
$$

which implies that $r_{e, t}$ and $\mu_{t}$ are perfectly correlated. Therefore, the implied cost of capital is a perfect proxy for the conditional expected return in an $\mathrm{AR}(1)$ framework.

We also consider a modified version of the implied cost of capital, $r_{e 2, t}$ :

$$
r_{e 2, t}=k+\frac{\gamma}{1-\delta}+\left(d_{t}-p_{t}\right)(1-\rho)
$$

This expression is obtained from equation (7) by setting $g_{t}$ equal to its unconditional mean of $\gamma /(1-\delta)$. This definition of $r_{e 2, t}$ captures the idea that our information about dividend growth is often limited in practice. Note that $r_{e 2, t}$ is perfectly correlated with the dividendprice ratio, which is commonly used to proxy for expected return. Since dividends tend to vary less than prices, the time variation in $r_{e 2, t}$ is driven mostly by the time variation in $p_{t}$. 


\section{Simulation}

This section builds on the framework developed in Section 2. First, we make additional assumptions about the conditional variance of stock returns. We impose a positive relation between the conditional mean and variance, and then we analyze the ability of various proxies for the conditional mean to detect this relation in simulated data. We show that the proxy proposed in this paper, the implied cost of capital, is well suited for capturing the intertemporal risk-return tradeoff.

\subsection{The Variance of Stock Returns}

Let $\sigma_{t}^{2} \equiv \operatorname{Var}_{t}\left(r_{t+1}\right)$ denote the conditional variance of stock returns. We assume that the conditional variance is related to the conditional mean as follows:

$$
\mu_{t}=a+b \sigma_{t}^{2}+e_{t}, \quad b>0, \quad e_{t} \sim N\left(0, \sigma_{e}^{2}\right) 1_{\left\{e_{t} \leq \bar{e}_{t}\right\}},
$$

so that $e_{t}$ is drawn from a truncated normal distribution with an upper bound of $\bar{e}_{t}$. The truncation of $e_{t}$ ensures nonnegativity of the variance draws, as explained below. We assume the risk-free rate of zero, so that $\mu_{t}$ can also be thought of as expected excess return.

Equation (13) defines the process for $\sigma_{t}^{2}$, conditional on $\mu_{t}: \sigma_{t}^{2}=\left(\mu_{t}-a-e_{t}\right) / b$. In the absence of the truncation of $e_{t}, \sigma_{t}^{2}$ would follow an $\mathrm{AR}(1)$ process with an autoregressive parameter equal to $\beta$. In the presence of the truncation, $\sigma_{t}^{2}$ follows a process that is approximately autoregressive. Note that the strength of the mean-variance association in equation (13) can be measured as $\sigma_{u}^{2} /\left(\sigma_{u}^{2}+\sigma_{e}^{2}\right)$, which is approximately equal to the fraction of the conditional variance of $\sigma_{t}^{2}$ that can be explained by the conditional variance of $\mu_{t}$.

We show in the Appendix that the return variance in the framework developed in Section 2. can be approximated by

$$
\operatorname{Var}_{t}\left(r_{t+1}\right)=\frac{1}{(1-\rho \delta)^{2}} \sigma_{v}^{2}+\frac{\rho^{2}}{(1-\rho \beta)^{2}} \sigma_{u}^{2}
$$

This expression is detached from the process for $\sigma_{t}^{2}$ defined in equation (13). To ensure that $\sigma_{t}^{2}$ can be interpreted as the variance of stock returns, we make $\sigma_{v}^{2}$ from equation (4) vary over time in a way that equates $\sigma_{t}^{2}$ from equation (13) to $\operatorname{Var}_{t}\left(r_{t+1}\right)$ from equation (14):

$$
\sigma_{v, t+1}^{2}=(1-\rho \delta)^{2}\left(\sigma_{t}^{2}-\frac{\rho^{2}}{(1-\rho \beta)^{2}} \sigma_{u}^{2}\right) \text {. }
$$

Since $\sigma_{v, t+1}^{2}$ must be nonnegative, $\sigma_{t}^{2} \geq \bar{\sigma}^{2}$ must hold in each period, where $\bar{\sigma}^{2}=\frac{\rho^{2}}{(1-\rho \beta)^{2}} \sigma_{u}^{2}$. To ensure that this inequality holds for each draw of $\sigma_{t}^{2}$, we truncate the distribution of $e_{t}$ in equation (13) at $\bar{e}_{t}=\mu_{t}-a-b \bar{\sigma}^{2}$. 
The first term in equation (14) captures the return variance that is due to news about dividend growth. The second term captures the variance due to news about expected future returns. The fraction of the return variance that is explained by the variation in expected return is therefore given by $\phi_{t}=\rho^{2} \sigma_{u}^{2} /\left((1-\rho \beta)^{2} \sigma_{t}^{2}\right)$. Replacing $\sigma_{t}^{2}$ by its unconditional mean yields an unconditional value of $\phi_{t}$, which we denote by $\phi$.

\subsection{The Simulation Procedure}

In this subsection, we describe how we simulate the time series of $\mu_{t}, \sigma_{t}^{2}, r_{t}, r_{e, t}$, and $r_{e 2, t}$, and how we use these time series to analyze the intertemporal risk-return relation.

The parameters are specified as follows. In equation (8), we choose $\alpha=0.25 \%$ per month and $\beta=0.8$, which implies an unconditional expected return of $15 \%$ per year. In equation (13), we choose $a=0.5 \%$ per month and $b=2.7778$, which implies an unconditional return variance of $(18 \%)^{2}$ per year. In equation (4), we choose $\gamma=0.16 \%$ per month and $\delta=0.8$, which implies an unconditional mean of $g_{t}$ equal to $10 \%$ per year. We solve for $\rho$ and $k$ numerically, and obtain $\rho=0.9955$ and $k=0.0291$. The variable $\sigma_{u}$ in equation (8) takes five different values $(0.34,0.58,0.75,0.89,1.01) \%$ per month, selected so that the fraction of the return variance that can be explained by the variation in expected return, earlier denoted by $\phi$, takes the values of $(0.1,0.3,0.5,0.7,0.9)$. For each value of $\sigma_{u}$, the value of $\sigma_{e}$ in equation (13) is selected so that the strength of the mean-variance link (i.e., $\sigma_{u}^{2} /\left(\sigma_{u}^{2}+\sigma_{e}^{2}\right)$, or the fraction of the variance of $\sigma_{t}^{2}$ that can be explained by the variation in $\left.\mu_{t}\right)$ takes the values of $(0.1,0.3,0.5,0.7,0.9)$.

The variables $g_{0}, \mu_{0}$, and $\sigma_{0}$ are initialized at their unconditional values, $d_{0}=0$, and the initial price is computed from equation (10) as $p_{0}=f_{1}\left(g_{0}, \mu_{0}, d_{0}\right)$. The following process is repeated in each period $t, t=1, \ldots, T$, conditional on the information up to time $t-1$ :

1. Compute $\sigma_{v, t}$ from equation (15).

2. Draw $g_{t}$ from equation (4).

3. Construct $d_{t}=d_{t-1}+g_{t}$.

4. Draw $\mu_{t}$ from equation (8).

5. Compute the price, $p_{t}=f_{1}\left(g_{t}, \mu_{t}, d_{t}\right)$, from equation (10).

6. Compute the implied cost of capital, $r_{e, t}=f_{2}\left(g_{t}, p_{t}, d_{t}\right)$, from equation (7). Also compute the modified implied cost of capital, $r_{e 2, t}=f_{3}\left(p_{t}, d_{t}\right)$, from equation (12). 
7. Draw $\sigma_{t}$ from equation (13).

8. Compute the realized return as $r_{t}=\log \left(\left(P_{t}+D_{t}\right) / P_{t-1}\right)$.

This process generates the time series of all variables used in the following subsection.

\subsection{The Simulation Results}

In this subsection, we use the time series simulated in Section 3.2. to estimate the intertemporal relation between the conditional mean and variance of returns. We consider the regression

$$
\mu_{t}=c+d \sigma_{t}^{2}+\epsilon_{t}
$$

with three proxies for $\mu_{t}: r_{e, t}, r_{e 2, t}$, and $r_{t+1}$. The realized return, $r_{t+1}$, is a common proxy for $\mu_{t}$ in this literature (see the references in footnote 3 ). Our objective is to examine the performance of the first two proxies relative to $r_{t+1}$ in detecting the positive risk-return relation $(d>0)$, which is imposed in the simulation $(b>0$ in equation (13)). We also run the regression (16) in first differences of $\mu_{t}$ and $\sigma_{t}^{2}$.

We consider five sample sizes: $T=60,120,240,360$, and 600 months. For each sample size, we simulate 5,000 time series of $r_{e, t}, r_{e 2, t}, r_{t+1}, \mu_{t}$, and $\sigma_{t}^{2}$. For each time series, we run the regression (16), and record the estimated slope coefficient $\hat{d}$. We take the average of the $5,000 \hat{d}$ 's to be the true value of $d$, given the large number of simulations. The " $t$-statistic" is computed by dividing the average $\hat{d}$ by the standard deviation of the $5,000 \hat{d}$ 's. In the same manner, we compute the true correlations between $\sigma_{t}^{2}$ and the three proxies for $\mu_{t}$.

Table 1 reports the correlations and their $t$-statistics. As the strength of the meanvariance link increases (i.e., as we move from the left to the right in the table), all correlations increase, along with their significance. As $T$ increases (i.e., as we move down the table), the correlations remain about the same, but their significance increases. Neither result is surprising: It is easier to detect a stronger mean-variance link, especially in large samples.

Table 1 shows a clear ranking among the three proxies for $\mu_{t}$ in terms of their ability to detect the positive risk-return relation. The highest and most significant correlations with $\sigma_{t}^{2}$ are achieved by $r_{e, t}$ and the lowest by $r_{t+1}$. This ranking is the same for all five values of $T$, all five degrees of the mean-variance link, and all five values of $\phi$. For example, for $T=120$ and the 0.5 values of the mean-variance link and $\phi$, the correlations achieved by $r_{e, t}, r_{e 2, t}$, and $r_{t+1}$ are $0.72(t=11.05), 0.40(t=3.08)$, and $0.14(t=1.22)$, respectively. 
The best performance of $r_{e, t}$ is not surprising, given the perfect correlation between $r_{e, t}$ and $\mu_{t}$ (equation (11)). More interesting is that $r_{t+1}$ is uniformly outperformed not only by $r_{e, t}$ but also by $r_{e 2, t}$. Recall that $r_{e 2, t}$ is the implied cost of capital computed under the assumption that log dividend growth, $g_{t}$, is equal to its unconditional mean. In practice, we (and the equity analysts whose forecasts we use in the empirical work) often have little information about future cash flow. Our results show that the implied cost of capital can help us estimate the intertemporal risk-return relation even in the absence of such information.

Since the time variation in $r_{e 2, t}$ is driven mostly by $p_{t}$, the ability of $r_{e 2, t}$ to detect the positive risk-return tradeoff stems from the fact that price changes tend to be accompanied by variance changes in the opposite direction. As long as price changes are to some extent driven by changes in $\mu_{t}$ (i.e., $\phi>0$ ), and $\mu_{t}$ is positively related to $\sigma_{t}^{2}$, then the regression of $r_{e 2, t}$ on $\sigma_{t}^{2}$ should detect the positive relation between $\mu_{t}$ and $\sigma_{t}^{2}$ in a long enough sample. Table 1 shows that $r_{e 2, t}$ works better as $\phi$ increases, which is not surprising. More important, $r_{e 2, t}$ works well even for relatively low values of $\phi$ and relatively small sample sizes. For example, for $\phi=0.3, T=120$, and the mean-variance link of 0.5 , the estimated correlation between $r_{e 2, t}$ and $\sigma_{t}^{2}$ is $0.36(t=2.66)$. The empirical estimates of $\phi$ are generally in the neighborhood of 0.7 (e.g., Campbell and Ammer, 1993). For $\phi=0.7, r_{e 2, t}$ has a significant correlation with $\sigma_{t}^{2}$ even for $T$ as low as 60 months and the mean-variance link as low as 0.3 . Even when the link is only 0.1 , the correlation is significant for $T \geq 240$ months, or 20 years. These results show that even $r_{e 2, t}$ can be quite useful in estimating the risk-return tradeoff.

In contrast, $r_{t+1}$ performs poorly. Its correlation with $\sigma_{t}^{2}$ is never significant for $T \leq 60$ months, even when the mean-variance link is 0.9 . When the link is 0.7 , we need at least a 20-year-long sample to find a significant relation between $r_{t+1}$ and $\sigma_{t}^{2}$, and when the link is 0.5, we need a 30-year-long sample. This evidence is consistent with Lundblad (2005), who shows in simulations that a very long sample is needed to precisely estimate the riskreturn relation using $r_{t+1}$. Realized returns are just too noisy to be very useful as proxies for expected return, at least relative to $r_{e, t}$ and $r_{e 2, t}$. Proxying for expected return by the implied cost of capital might allow us to detect a positive risk-return tradeoff in substantially shorter samples than would be required if we used realized returns. This fact seems useful especially in international markets, in which long return histories are often unavailable.

We have also estimated the regression (16) in first differences rather than levels, and obtained results that lead to exactly the same conclusions. Exactly the same conclusions are also reached based on the slope coefficients $\hat{d}$ rather than based on correlations. The results are robust to reasonably large changes in the parameter specification. 


\section{Empirical Methodology}

\subsection{The Methodology for Computing Implied Cost of Capital}

We compute the implied cost of equity capital for each firm as the internal rate of return that equates the present value of future dividends to the current stock price, following the approach of Gebhardt, Lee, and Swaminathan (2001) and Lee, Ng, and Swaminathan (2003). We use the term "dividends" quite generally to describe the free cash flow to equity (FCFE), which captures the total cash flow available to shareholders, net of any stock repurchases and new equity issues. The stock valuation formula in equation (1) expresses the stock price in terms of an infinite series, but we explicitly forecast free cash flow only over a finite horizon, and capture the free cash flow beyond the last explicit forecast period in a "terminal value" calculation. In other words, the value of a firm is computed in two parts, as the present value of free cash flow up to the terminal period $t+T$, plus the present value of free cash flow beyond the terminal period. We compute future free cash flow up to year $t+T+1$ as the product of annual earnings forecasts and one minus the plowback rate:

$$
E_{t}\left(F C F E_{t+k}\right)=F E_{t+k} \times\left(1-b_{t+k}\right),
$$

where $F E_{t+k}$ and $b_{t+k}$ are the forecasts of earnings and the plowback rate for year $t+k$. The plowback rate is the fraction of earnings that is reinvested in the firm, or one minus the payout ratio. The earnings forecasts for years $t+1$ through $t+3$ are based on analyst forecasts, and the forecasts from year $t+4$ to year $t+T+1$ are computed by mean-reverting the year $t+3$ earnings growth rate to its steady-state value by year $t+T+2$. We assume the steady-state growth rate starting in year $t+T+2$ to be equal to the long-run nominal GDP growth rate, $g$, computed as the sum of the long-run real GDP growth rate (a rolling average of annual real GDP growth) and the long-run average rate of inflation based on the implicit GDP deflator (more details are provided below). We further impose an exponential rate of decline to mean-revert the year $t+3$ growth rate to the steady-state growth rate. ${ }^{5}$ Specifically, we compute earnings growth rates and earnings forecasts for years $t+4$ to $t+T+1(k=4, \ldots, T+1)$ as follows:

$$
\begin{aligned}
g_{t+k} & =g_{t+k-1} \times \exp \left[\log \left(g / g_{t+3}\right) /(T-1)\right], \\
F E_{t+k} & =F E_{t+k-1} \times\left(1+g_{t+k}\right) .
\end{aligned}
$$

\footnotetext{
${ }^{5}$ We choose the exponential rate of decline to be consistent with the empirical evidence that growth rates of earnings mean-revert rapidly (e.g., Chan, Karceski, and Lakonishok (2002)). Given this rapid mean reversion, any potential biases in analysts' short-term earnings forecasts should not have large effects on the long-run growth rates, and therefore also on our estimates of the implied cost of capital.
} 
We forecast plowback rates in two stages: (a) we explicitly forecast plowback rates for years $t+1$ and $t+2$ (see the next section), and (b) we mean-revert the plowback rates between years $t+2$ and $t+T+1$ linearly to a steady-state value computed from the sustainable growth rate formula. ${ }^{6}$ This formula assumes that, in the steady-state, the product of the steady-state return on new investments, $R O I$, and the steady-state plowback rate is equal to the steady-state growth rate in earnings (see Brealey and Myers (2002)); i.e, $g=R O I \times b$. We then set $R O I=r_{e}$ for new investments in the steady state, assuming that competition drives returns on these investments down to the cost of equity. Thus, our main assumptions are that the earnings growth rate reverts to the long-run nominal GDP growth rate, and that the return on new investment, ROI, reverts to the (implied) cost of equity, $r_{e}$.

Substituting $R O I=r_{e}$ in the sustainable growth rate formula and solving for $b$ provides the steady-state value for the plowback rate, $b=g / r_{e}$. The intermediate plowback rates from $t+3$ to $t+T(k=3, \ldots, T)$ are computed as follows:

$$
b_{t+k}=b_{t+k-1}-\frac{b_{t+2}-b}{T-1} .
$$

The terminal value at time $t+T, T V_{t+T}$, is computed as the present value of a perpetuity equal to the ratio of the year $t+T+1$ earnings forecast divided by the cost of equity:

$$
T V_{t+T}=\frac{F E_{t+T+1}}{r_{e}},
$$

where $F E_{t+T+1}$ is the earnings forecast for year $t+T+1$. Note that the use of the no-growth perpetuity formula does not imply that earnings or cash flows do not grow after period $t+T$. Rather, it simply means that any new investments after year $t+T$ earn zero economic profits. In other words, any growth in earnings or cash flows after year $T$ is value irrelevant.

Substituting equations (17) to (21) into the infinite horizon free cash flow valuation model in equation (1) provides the following empirically tractable finite-horizon model:

$$
P_{t}=\sum_{k=1}^{T} \frac{F E_{t+k}\left(1-b_{t+k}\right)}{\left(1+r_{e}\right)^{k}}+\frac{F E_{t+T+1}}{r_{e}\left(1+r_{e}\right)^{T}} .
$$

We use a fifteen-year horizon $(\mathrm{T}=15)$, following Lee, $\mathrm{Ng}$, and Swaminathan (2003).

\subsubsection{Earnings Forecasts over the First Three Years}

We obtain explicit earnings forecasts for years $t+1$ and $t+2$ from the $\mathrm{I} / \mathrm{B} / \mathrm{E} / \mathrm{S}$ database. I/B/E/S analysts supply one-year-ahead and two-year-ahead earnings per share (EPS) fore-

\footnotetext{
${ }^{6}$ We assume that year $t+k$ plowback affects year $t+k+1$ earnings growth. We assume a linear decline in the plowback rate because plowback rates appear to mean-revert slower than earnings growth rates.
} 
casts for each firm, as well as an estimate of the long-term growth rate $(\mathrm{Ltg})$. We use the consensus (mean) one- and two-year-ahead EPS forecasts $\left(F E_{t+1}\right.$ and $\left.F E_{t+2}\right)$, and we compute a three-year-ahead earnings forecast as $F E_{t+3}=F E_{t+2} \times(1+L t g)$. If $L t g$ is not available, we estimate the growth rate for year $t+3$ from the consensus forecasts in years 1 and 2: $g_{t+3}=F E_{t+2} / F E_{t+1}-1$, and use this growth rate to compute a three-year ahead earnings forecast: $F E_{t+3}=F E_{t+2}\left(1+g_{t+3}\right)$. Firms with growth rates above $100 \%$ (below $2 \%$ ) are assigned values of $100 \%(2 \%)$.

\subsubsection{Plowback Rates}

For each U.S. firm, we compute the plowback rate $\left(b_{t}\right)$ for the first three years as one minus the firm's most recent net payout ratio $\left(p_{t}\right)$. To compute $p_{t}$, we first compute net payout $\left(N P_{t}\right)$ as gross payout (i.e., dividends plus share repurchases) minus any issuance of new stock: $N P_{t}=D_{t}+R E P_{t}-N E_{t}$, where $D_{t}$ is the amount of common dividends paid by the firm in year $t$ (COMPUSTAT item D21), $R E P_{t}$ is the amount of common and preferred stock purchased by the firm in year $t$ (item D115), and $N E_{t}$ is the amount of common and preferred stock sold by the firm in year $t$ (item D108). We then compute the net payout ratio, $p_{t}$, as $N P_{t} / N I_{t}$, where $N I_{t}$ is the firm's net income in year $t$ (item D18). If the firm's $N P_{t} / N I_{t}$ is not available, we compute $p_{t}$ as $N P_{t} / F E_{t+1}$, where $F E_{t+1}$ is the one-year ahead earnings forecast from $\mathrm{I} / \mathrm{B} / \mathrm{E} / \mathrm{S}$. If even that quantity is unavailable, $p_{t}$ is computed as the median $N P_{t} / N I_{t}$ across all firms in the corresponding industry-size portfolio. The industrysize portfolios are formed each year by first sorting firms into 48 industries, based on the Fama-French classification, and then forming three equal-number-of-firms portfolios based on market capitalization within each industry. If $p_{t}$ is above 1 or below -0.5 , we set it equal to the median $N P_{t} / N I_{t}$ of the industry-size portfolio. Also, industry-size portfolios with a median $N P_{t} / N I_{t}$ below -0.5 are given a value of -0.5 . As a result, the net payout ratio is bounded above by 1.0 and below by -0.5 . To ensure that our computations are based on publicly available information, we require the fiscal year-end to be at least three months prior to the date of computation of the cost of equity.

For the other G-7 countries, due to data availability, we use a simpler approach to estimate the payout ratio. If dividends and positive earnings are available for the prior fiscal year, we use the dividend payout ratio. For firms experiencing negative earnings, we divide the dividends paid by $6 \%$ of total assets. Since the long-run return on assets is $6 \%$ in the U.S., we use $6 \%$ of total assets as an estimate of normal earnings when earnings are negative in the other G-7 countries (see Gebhardt, Lee, and Swaminathan, 2001). 
Given our forecasts of earnings and plowback rates, we compute the implied cost of equity capital, $r_{e}$, from equation (22) for each firm at each month-end. To trim the outliers, we delete the top $0.5 \%$ and the bottom $0.5 \%$ of the values of the implied cost of capital in each month. We then compute the country-level cost of capital as an equal-weighted or valueweighted average of the individual firm costs of capital. The value weights are based on market values at the most recent year-end. Finally, we compute the implied risk premium for each G-7 country as the implied cost of equity capital minus the local risk-free rate, which is described in the following section.

\subsection{Data}

We obtain return data from CRSP (for U.S. firms) and Datastream (for non-U.S. firms), accounting data from Compustat (U.S.) and Worldscope (non-U.S.), and analyst forecasts from I/B/E/S (for both U.S. and non-U.S. firms). To ensure a reasonable number of firms in each country, we limit our analysis to the period of January 1981 to December 2002 for the U.S., and January 1990 to December 2002 for the other six countries.

We require firms to have monthly price and share outstanding numbers available in I/B/E/S. For U.S. firms, monthly data on market capitalization are obtained from CRSP. We require the availability of the following data items: common dividend, net income, book value of common equity, fiscal year-end date, and currency denomination. These items come from the most recent fiscal year ending at least six months (three months in the case of the U.S.) prior to the month in which the cost of capital is computed. As discussed above, for U.S. firms, we also require data on share repurchases and new stock issuance to compute the net payout ratio. We exclude ADRs and firms with negative common equity. We use $\mathrm{I} / \mathrm{B} / \mathrm{E} / \mathrm{S}$ to obtain monthly data on one-year and two-year consensus EPS forecasts and estimates of the long-term growth rate, all in local currency.

To measure market returns, we use monthly returns on the CRSP value-weighted index for the U.S, and monthly local-currency returns on the MSCI index for the other six countries. Data on nominal GDP growth rates are obtained from the Bureau of Economic Analysis (U.S. Department of Commerce) and World Bank. Each year, we compute the "steady-state" GDP growth rate as the historical average of the GDP growth rates, using annual data up to that year. For the U.S., our GDP growth rate series begins in 1930. For France, Italy, Japan, and U.K., GDP growth rates are available from 1961. For Canada and Germany, these data begin in 1966 and 1972, respectively. 
For non-U.S. firms, I/B/E/S reports analyst forecasts, price, and shares outstanding within a few days after the 15th of each month. Therefore, we compute the implied cost of capital for non-U.S. firms as of mid-month. For consistency, we compute monthly returns from the first trading day after the 15th of the previous month to the first trading day after the 15 th of the current month. Each month, we also estimate the conditional variance and standard deviation of market returns using mid-month to mid-month daily returns. For U.S. firms, we obtain month-end price data from CRSP, and compute monthly returns and volatilities from the beginning to the end of the month.

For each country, we compute the implied risk premium as the implied cost of equity capital minus the yield to maturity on the local 10-year government bond (obtained from Datastream). ${ }^{7}$ The only exception is Italy, for which we use the 7 -year bond series because the data series for the 10-year bond starts later. For the U.S., we use month-end bond yields since we compute the month-end cost of capital. For the other countries, we use mid-month yields to match the timing of the cost of capital estimates.

To compute realized excess returns, we subtract the local one-month risk-free rate from realized returns. For the risk-free rate, we use monthly returns on a one-month Treasury bill for the U.S., Canada, and U.K. Data on U.S. T-bill rates are obtained from Kenneth French's website, and data on the T-bill rates in Canada and U.K. are obtained from Datastream. For the other four countries, the T-bill rates are not available for the entire sample period, so we use the inter-bank one-month offer rates provided by the British Bankers Association (BBA), also obtained from Datastream. ${ }^{8}$ Datastream provides two series on inter-bank offer rates - one provided by BBA and another that originates within the country. We use the former since there is a longer time series of data available for the BBA series in most countries. The rates on the two series are very similar for most countries, except for Japan where the rate provided by BBA is $0.03 \%$ below the local inter-bank rate. We use the BBA series for Japan since the data go back to 1989, whereas the data on local rates start only in 1995 .

How do the inter-bank rates compare to one-month T-bill rates? We compare these two rates in the countries where they are both available. In Canada, the average spread of the inter-bank rate over the T-bill rate is $0.23 \%$ (annualized) over the period 1990-2003. In the U.K., the spread is very similar, about $0.24 \%$. We also compare the inter-bank rates to the euro-currency rates and find only marginal differences. For example, in the U.K., the

\footnotetext{
${ }^{7}$ Claus and Thomas (2001) also use the 10-year risk-free rate to construct the risk premium from the implied cost of capital.

${ }^{8}$ For Italy, both short-term and long-term risk-free rates are available starting July 1990. For this reason, all regressions for Italy start in July 1990.
} 
inter-bank rates are about $0.01 \%$ higher than the euro-pound rates.

Table 2 provides the summary statistics on the implied risk premia and return volatilities (annualized monthly standard deviations computed from daily returns) for the G-7 countries. The average equal-weighted risk premium varies from $4.2 \%$ in Italy to $8.1 \%$ in Canada. The value-weighted averages are smaller, ranging from $0.6 \%$ in Italy to $4.7 \%$ in Canada. These estimates are similar to those found in Lee, $\mathrm{Ng}$, and Swaminathan (2003). The average standard deviation of returns varies from $13.7 \%$ in the U.S. and Canada to $20.8 \%$ in Italy. The table also provides the average number of firms per month in each country. The U.S. has the highest average number firms (1,795), Italy has the lowest (115).

Figures 1 through 4 plot the monthly time series of the implied risk premiums in all seven countries, along with the time series of the country return volatilities. The equalweighted U.S. implied risk premium in Figure 1 fluctuates between $1 \%$ and $8 \%$ between January 1981 and December 2002, with most of the values falling in the $4 \%$ to $6 \%$ range. The value-weighted U.S. premium fluctuates between 0 and $6 \%$, but mostly between $2 \%$ and $4 \%$, consistent with the findings of Claus and Thomas (2001). In most of the seven countries, the implied risk premium rises in the 1990s. This rise is partly due to significant increases in the analysts' cash flow expectations in the 1990s, and partly due to the contemporaneous declines in the risk-free rates in most countries. When the risk-free rates are added back to plot the implied costs of capital, the upward trend remains apparent only for Germany and Japan, and the implied cost of capital in the U.S. exhibits a clear decline.

Several studies find that analyst forecasts tend to be systematically biased upward. Given this bias, the true risk premia may well be lower than those reported in Figures 1 through 4. Note, however, that we are interested in the time variation in the risk premia, so if the bias is constant over time, it has no effect on our results. Even if the bias varies over time, it has no effect on our results as long as its time variation is uncorrelated with market return volatility. In order to artificially create our results, the bias would have to be significantly positively correlated with market volatility. We are not aware of any empirical evidence establishing such correlation. Moreover, we do not find any significant correlation between analyst forecast errors and market volatility in our subsequent analysis in Section 5.5.

\section{Empirical Results}

This section presents our main empirical findings. For each G-7 country, we regress estimates of the conditional mean return on the conditional market volatility. We consider the same 
regression specifications as in Section 3., as well as a few additional ones.

Since Merton's ICAPM postulates a positive relation between the conditional mean and variance of market returns, variance seems to be more relevant than standard deviation as a measure of market volatility. Nonetheless, we consider not only variance $\left(\sigma_{t}^{2}\right)$ but also standard deviation $\left(\sigma_{t}\right)$, as one way of assessing the sensitivity of our results. The units of volatility correspond to the units of the variable on the other side of the regression. When the dependent variable is monthly returns, volatility is in monthly units. When the dependent variable is the annualized implied risk premium, volatility is annualized as well.

In most of our analysis, we ignore any potential hedging demands (Merton, 1973), as does Merton (1980) and others. However, in Section 5.4., we show that including popular proxies for hedging demands has little effect on our results for the U.S. market.

\subsection{Volatility and Realized Returns}

We begin by using realized excess market return at time $t+1, r_{t+1}$, as a proxy for expected excess market return at time $t$. We regress this proxy on market volatility $V o l_{t}\left(\sigma_{t}^{2}\right.$ or $\left.\sigma_{t}\right)$ :

$$
r_{t+1}=a+b \mathrm{Vol}_{t}+e_{t+1} .
$$

This regression is an empirical analogue to the simulated regression in equation (16).

Table 3 presents the regression estimates. There is no evidence of a positive relation between market volatility and the next month's realized return. The estimates of $b$ are not significantly different from zero in any of the seven countries. In fact, in three countries, the estimates of $b$ are (insignificantly) negative. ${ }^{9}$ All adjusted R-squareds in Table 3 are low, confirming the fact that this month's volatility has very little predictive power for the next month's return. In short, these results confirm our simulation evidence (as well as the simulation evidence of Lundblad (2005)) that it is difficult to detect a positive mean-variance relation in tests that use realized returns to proxy for expected returns.

\subsection{Volatility and the Implied Risk Premia}

Next, we consider several regression specifications with the implied risk premium $\mu_{t}$ :

$$
\mu_{t}=a+b \mathrm{Vol}_{t}+e_{t},
$$

\footnotetext{
${ }^{9}$ The $t$-statistics are corrected for potential residual autocorrelation using one Newey-West lag. We have also examined the regression specification with first differences in volatility in place of the levels, and found similar results (i.e., no significant slopes).
} 


$$
\begin{aligned}
\mu_{t} & =a+b V_{o l}+c \mu_{t-1}+e_{t}, \\
\mu_{t} & =a+b \Delta V \operatorname{Vol}_{t}+c \mu_{t-1}+e_{t}, \\
\Delta \mu_{t} & =a+b \Delta V o l_{t}+e_{t}, \\
\epsilon_{\mu, t} & =a+b \epsilon_{V, t}+e_{t}
\end{aligned}
$$

where $\mu_{t}$ is the implied risk premium at the end of month $t$, measured as the difference between the implied cost of capital $\left(r_{e, t}\right)$ and the risk-free rate, $\Delta \mu_{t}=\mu_{t}-\mu_{t-1}, \epsilon_{\mu, t}$ is the residual from an $\mathrm{AR}(1)$ model estimated for $\mu_{t}$ in the full sample, and $\epsilon_{V, t}$ is the analogous $\operatorname{AR}(1)$ residual for volatility $\left(\sigma_{t}^{2}\right.$ or $\left.\sigma_{t}\right)$.

Regressions (26) to (28) examine the relations between shocks to volatility and shocks to expected returns. A test involving shocks may be more powerful in testing the meanvariance relation than a test involving levels because any persistent biases in the estimates of the conditional mean and volatility should not influence the monthly shocks. Regression (27) uses changes in $\mu_{t}$ and $V o l_{t}$ as proxies for shocks to the risk premium and volatility. To assess the robustness of our results with respect to different shock specifications, we regress the level of $\mu_{t}$ on lagged $\mu_{t}$ and the levels or changes in volatility (equations (25) and (26)). We also estimate AR(1) processes independently for expected returns and volatility, and then regress the residuals from the expected return model on the residuals from the volatility model (equation (28)). To correct the standard errors for potential autocorrelation, we use 12 Newey-West lags in regression (24) and one lag for all other specifications. We use more lags for regression (24) because $\mu_{t}$ is highly persistent.

Table 4 presents the results in the case where the country-level implied risk premium is the equal-weighted average of the individual firm risk premia. First, consider regression (24). Using $\sigma_{t}$ as a measure of volatility, the risk-return relation is positive $(b>0)$ for all G-7 countries, and the relation is statistically significant in all countries but Italy and Japan. Using $\sigma_{t}^{2}$ to measure volatility, the risk-return relation is again significantly positive for five of the seven countries. In regression (25), the risk-return relation is positive and significant in Canada, France, U.K., and U.S. In regressions (26) to (28), we find a statistically significant positive relation between shocks to the risk premia and shocks to volatility in Canada, France, Germany, U.K., and U.S. In Japan, the relation is also positive but marginally insignificant. Only in Italy, the country with the lowest number of firms in the sample, does the slope coefficient have the wrong sign (statistically insignificant). These results are robust to using variance or standard deviation as a measure of volatility. In sum, the results reveal a strong positive relation between the risk premium and market volatility. We find it striking that our results are statistically significant in so many cases, despite the relatively short samples 
used in the estimation (22 years for the U.S., and 13 years for the other six countries).

Table 5 is an equivalent of Table 4, with the equal-weighted country risk premia replaced by the value-weighted ones, where the weights are based on the market values of equity at the most recent year-end. As in Table 4, the regression (24) uncovers a positive mean-variance relation. This relation is statistically significant in four countries (France, Germany, Italy, and U.K.), and it is insignificantly positive in Canada and the U.S. The regressions based on shocks find a significantly positive mean-variance relation in France, U.K., and the U.S. The value-weighted evidence is somewhat weaker than the equal-weighted evidence.

Should we pay more attention to the results in Table 4, where the costs of capital are equal-weighted across firms in computing the country-level cost of capital, or to the results in Table 5, where the costs are value-weighted? Equal-weighting typically pays disproportionate attention to small firms, but it would be misleading to argue that the results in Table 4 are driven by small firms. The firms in our sample are a subset of firms in any given country (see Table 2), and this is not a random subset because firms that satisfy our data requirements (which include analyst forecasts) tend to be among the largest firms in their countries. As a result, value-weighting focuses on the largest among these already large firms, which overweights the largest firms relative to the country's market portfolio. Equal-weighting pays more attention to smaller firms in our large-firm subsets, which partly compensates for the absence of truly small firms in our sample. It is not clear whether value-weighting or equal-weighting produces an aggregate expected return that is closer to the expected return on the country's true market portfolio, so we consider both Tables 4 and 5 informative.

The regressions in Tables 4 and 5 are estimated separately for each individual country. To test if the estimated positive mean-variance relation is jointly significant across the G-7 countries, we estimate a multivariate seemingly unrelated regression (SUR) model involving all 7 countries for each of the five regression specifications. A joint F-test of the hypothesis that all seven slope coefficients are equal to zero rejects the null for each specification.

Table 6 reports the Spearman correlations between the levels and changes in the risk premia and the levels and changes in volatility for each G-7 country, to provide a sense of the economic significance of the risk-return relation. The results generally show a strong positive relation between the levels of the risk premium and volatility. The correlation between the equal-weighted premium and volatility ranges from $13 \%$ for Italy to $60 \%$ for U.K. The correlation between the value-weighted premium and volatility ranges from $10 \%$ to $45 \%$. The correlations between the changes in the risk premium and changes in volatility are also positive but lower in magnitude and not as statistically significant. The correlation 
results are consistent with the regression results presented in Tables 4 and 5.

Overall, the results in Tables 4 through 6 show a positive relation between the conditional mean and volatility of the country-level market returns. The difference between the results in Table 3 and Tables 4 through 6 confirms our simulation findings that a positive intertemporal mean-variance relation, if present, is easier to detect by using the implied cost of capital than by using the realized return as a proxy for expected return.

\subsection{Robustness: Implied Volatility}

So far, we have estimated conditional return volatility using the volatility realized over the previous month. This approach involves nontrivial estimation error, which biases our results against finding a mean-variance relation. In this subsection, we consider an alternative volatility estimator: the implied volatility from the options market.

Implied volatility data are available to us for the U.S. stock market over the period January 1986 through December 2002. We use the month-end series of the VXO index, which is based on the S\&P 100 options. The data are obtained from the CBOE. ${ }^{10}$

Table 7 contains the results from the regressions (24) through (28). The estimated riskreturn relation is unambiguously positive. For example, consider regression (27), in which first differences in the implied premium are regressed on first differences in implied volatility. Across four specifications ( $\sigma^{2}$ and $\sigma$, equal-weighted and value-weighted implied premium), the $t$-statistics for the slope coefficient range from 9.77 to 10.47. Based on the residuals in $\mu_{t}$ and $\sigma_{t}^{(2)}$ (regression (28)), the $t$-statistics range from 9.24 to 11.24. This level of statistical significance is striking, given the relatively short sample period (17 years of monthly data). It appears that implied volatility contains less estimation error than realized volatility.

\subsection{Robustness: Hedging Demands}

According to Merton (1973), the conditional expected excess market return depends not only on the conditional variance of market returns but also on hedging demands, i.e., on the market's covariance with the state variables that capture investment opportunities. Scruggs (1998) and Guo and Whitelaw (2005) argue that hedging demands are important in uncovering a positive mean-variance relation. Although we find this relation even without including

\footnotetext{
${ }^{10}$ The VXO index used to be known as the VIX index until CBOE modified the VIX methodology in September 2003 (it switched to the S\&P 500 index options and changed the index formula).
} 
hedging demands in our estimation, it seems useful to test whether the relation survives the inclusion of commonly used proxies for hedging demands.

We model hedging demands as a linear combination of five macroeconomic variables that have been used in prior studies. The first variable is the excess return on the 30-year U.S. Treasury bond, obtained from CRSP. This variable is motivated by Scruggs (1998), who uses long-term government bond excess returns as a catch-all proxy for hedging demands. The other four variables follow Guo and Whitelaw (2005): the default spread (Baa-Aaa yield spread, obtained from the St. Louis Fed), the term spread (30-year minus one-month Treasury yield spread, obtained from CRSP), the detrended risk-free rate (the one-month T-bill rate in excess of its 12-month moving average), and the dividend-price ratio (extracted from the value-weighted CRSP market return series with and without dividends).

We add all five variables to the right-hand side of each regression summarized in Table 7 for the U.S. market, and report the results in Table 8. The inclusion of the hedging demand proxies has a relatively small effect on the estimated coefficients and their $t$-statistics. In

both Tables 7 and 8, the mean-variance relation is highly statistically significant in the same set of 18 out of 20 specifications. We conclude that the positive risk-return tradeoff in the U.S. is robust to controlling for popular proxies for hedging demands.

\subsection{Robustness: Analyst Forecast Errors}

We find a positive relation between market volatility and the implied risk premium, but the implied risk premium measures the true risk premium with error. If this measurement error is somehow positively related to market volatility, it could create an appearance of a positive mean-variance relation even if the true risk premium is unrelated to volatility.

To see if this is a problem, we need a proxy for the measurement error in the implied risk premium. The main source of this measurement error is that analyst forecasts may not perfectly capture the market's cash flow expectations. If analysts are more optimistic than the market, the implied risk premium is higher than the true risk premium, and vice versa. Therefore, we use analyst forecast errors as a proxy for the measurement error in the risk premium. We test whether these forecast errors are related to market volatility.

We compute analyst forecast errors for each firm and each month as the absolute value of the ratio of the difference between the consensus one-year-ahead analyst forecast of EPS (earnings per share) and the corresponding actual EPS to the one-year-ahead forecast. We then average the forecast errors across firms (equal-weighting or value-weighting) in each 
month to compute a market-wide forecast error for each of the G-7 countries. ${ }^{11}$ Finally, we run country-level regressions of forecast errors on the levels and changes in market variance, using all available data (1981-2002 for the U.S. and 1990-2002 for the other countries).

We do not find a significant relation between analyst forecast errors and market volatility in any of the G-7 countries, regardless of whether the forecast errors are equal-weighted or value-weighted. Although most point estimates of the slope coefficient are positive, none of them is statistically significant. (To save space, we do not report the results in a separate table.) Therefore, our finding of a positive mean-variance relation does not appear to be driven by analyst forecast errors.

\subsection{Integration of International Financial Markets}

So far, we have tested the conditional mean-variance relation separately for each country, which implicitly assumes that the G-7 financial markets are segmented. This section analyzes the risk-return tradeoff from a global perspective.

We begin by computing the aggregate risk premium across the G-7 countries by averaging the seven equal-weighted or value-weighted individual country risk premia. We refer to this premium as the world market risk premium, even though the G-7 markets account for only about $70 \%$ of the world market capitalization (as of 2002). We compute the world market volatility in each month from the daily returns on the MSCI value-weighted world market index. Because of the reporting differences on $\mathrm{I} / \mathrm{B} / \mathrm{E} / \mathrm{S}$ across the G-7 countries (see Section 4.2.), we compute monthly volatility in two ways: from the beginning of the month to the month-end, as well as mid-month to mid-month. We conduct three tests.

First, we assess the strength of the risk-return relation at the world market level by regressing the world market risk premium on the world market volatility. We run the same five regressions, equations (24) to (28), as we did at the country level. We do this for two definitions of the risk premium (equal-weighted and value-weighted) and two definitions of market volatility $\left(\sigma_{t}^{2}\right.$ and $\left.\sigma_{t}\right)$, which gives us four variations of each of the five regressions.

Table 9 shows a strong positive relation between the levels of the world market risk premium and the world market volatility. This relation is positive and statistically significant in all four panels. The relation between the shocks to the risk premium and to volatility is also positive in all four panels, but it is statistically significant only for the equal-weighted country risk premia. On balance, this evidence supports a positive intertemporal risk-return

\footnotetext{
${ }^{11}$ To eliminate outliers, we delete the top $0.5 \%$ of forecast errors in each country/month.
} 
tradeoff at the world market level.

Merton $(1973,1980)$ shows that the coefficient of proportionality between the conditional mean and variance can be interpreted as the coefficient of relative risk aversion, under certain assumptions. Therefore, our estimated slope coefficients in the level regression are estimates of relative risk aversion under Merton's assumptions. These slopes range from 0.28 to 0.67 across the four basic specifications. There are at least two reasons why these coefficients may understate the true average level of risk aversion in the economy. One, return volatility is measured with error, and the resulting attenuation bias makes the estimated slope coefficient smaller than the true coefficient. Two, under assumptions more general than Merton's, these slope coefficients do not necessarily represent relative risk aversion (e.g., Backus and Gregory (1993), Campbell (1993), Veronesi (2000)).

Second, we examine the cross-market risk-return relation by regressing the seven countrylevel risk premia on the world market volatility. We use both the equal-weighted and the value-weighted risk premia. To conserve space, we present only the results based on variance as a measure of volatility (the results based on standard deviation are similar).

Table 10 shows that, in six of the seven countries, the level of the equal-weighted risk premium is positively and significantly related to the world market volatility. Interestingly, this relation is stronger than the relation observed in Table 4, which uses the individual local market volatility in place of the world market volatility. That is, the country risk premia appear to be even more closely related to the world market volatility than to their own country's volatility. Table 10 also shows that the shocks to the equal-weighted risk premia are positively related to the volatility shocks, but this relation is statistically significant only in France, U.K., and the U.S. The results based on the value-weighted risk premia are similar. The level relation is positive and significant in four countries, and the relation involving shocks is statistically significant in three countries (France, U.K., U.S.).

Third, we analyze the relation between the implied country risk premia and the conditional covariances with the world market portfolio. This analysis is motivated by Chan, Karolyi, and Stulz (1992) who find that the U.S. risk premium is positively related to the conditional covariance of U.S. stocks with a foreign index but unrelated to its own conditional variance. For each G-7 country, we run five regressions of the risk premium on the conditional covariance between the country returns and the world market returns, as well as on the world market volatility. The conditional covariances with the world market portfolio are estimated simply from daily returns over the previous month. 
Table 11 reports the results. In the levels specification, we find a significantly positive relation between the risk premia and the conditional covariances in five of the seven countries, consistent with the international CAPM. In the other four specifications, the relation is estimated to be positive for all seven countries but it is almost never statistically significant. Compared to Table 10, including the conditional covariance in the regression causes the market variance to lose its significantly positive coefficient for all seven countries, similar to the result that Chan, Karolyi, and Stulz (1992) found for the United States.

The evidence in Tables 10 and 11 suggests that the country risk premia are affected by foreign asset returns, which is inconsistent with full segmentation of international markets. Instead, our evidence suggests that financial markets are at least partially integrated.

\subsection{Dividend Yield vs Implied Cost of Capital}

In Section 3., we show that when dividend growth follows an $\mathrm{AR}(1)$ process, the implied cost of capital is a simple function of the dividend yield $(\mathrm{D} / \mathrm{P})$ and dividend growth (see equation 7). The first component, $\mathrm{D} / \mathrm{P}$, is commonly used to capture time variation in expected return. The second component, dividend growth, reflects the market's expectations of future cash flow. If analyst forecasts are at least somewhat useful in estimating future cash flow, the implied cost of capital should better capture time variation in expected return than $\mathrm{D} / \mathrm{P}$ does. In this section, we reestimate the intertemporal risk-return relation by using $\mathrm{D} / \mathrm{P}$ (instead of the implied cost of capital) as a proxy for expected return.

Tables 12 and 13 are the counterparts of Tables 4 and 5, with the implied cost of capital replaced by D/P. For each country, we construct monthly D/P by equal-weighting (Table 12) or value-weighting (Table 13) the dividend yields of all firms in that country. Firm-level dividend yield is computed as the ratio of all dividends paid out in the most recent fiscal year to the market capitalization at the end of the current month. To proxy for the risk premium, we use the difference between the country-wide $\mathrm{D} / \mathrm{P}$ and the local risk-free rate.

The results show that $\mathrm{D} / \mathrm{P}$ is positively related to market volatility in several countries, as predicted by our simulation, but the relation is not as strong as that observed when using the implied cost of capital. In Table 13, the relation between $\mathrm{D} / \mathrm{P}$ and market variance is significantly positive for four countries based on levels, for two countries based on changes, and for three countries based on innovations. In contrast, in Table 4, the relation is significantly positive for five countries in all three specifications. Similarly, the value-weighted results are generally stronger in Table 5 than in Table 14. 
This evidence leads to two conclusions. First, since the results based on $\mathrm{D} / \mathrm{P}$ are weaker than those based on the implied cost of capital, analyst forecasts seem to contain useful information about expected return. Second, since even the results based on $\mathrm{D} / \mathrm{P}$ are significant in many specifications, the intertemporal risk-return relation seems reliably positive.

\section{Conclusions}

This paper reexamines the intertemporal risk-return tradeoff using a novel proxy for expected market return. This proxy, the implied cost of capital, is the internal rate of return computed from a discounted cash flow model. Our simulations show that the implied cost of capital outperforms realized return, a common proxy for expected return, in detecting a positive risk-return tradeoff. Using the implied cost of capital, we find strong empirical evidence of a positive relation between the conditional mean and variance of market returns in the G-7 countries, both at the country level and at the world market level. We find no such relation using realized returns to proxy for expected returns.

Most studies on this subject find either no relation or a negative relation between the conditional mean and variance of the U.S. market returns. The few recent studies that report a positive relation attribute their findings to a superior estimator of the conditional variance (Ghysels, Santa-Clara, and Valkanov (2005)), to the inclusion of hedging demands in the estimation (Scruggs (1998) and Guo and Whitelaw (2005)), or to a longer sample (Lundblad (2005)). In contrast, our study provides evidence of a positive mean-variance relation in an international framework without a long sample, without proxies for hedging demands, and without a sophisticated estimator for conditional variance. We attribute our results solely to our proxy for expected return, namely, the implied cost of capital.

This proxy is negatively related to market prices, by construction. Thus, the fact that this proxy reveals a positive mean-variance relation is to some extent due to the well known empirical fact that changes in market prices are negatively correlated with changes in market volatility (e.g., Black (1976)). We believe that the observed negative relation between prices and volatility is due to time-varying expected returns: increases in volatility lift expected returns, driving down prices. However, we show that volatility is more closely related to the implied cost of capital than to the dividend yield, which implies that there is more to the implied cost of capital than just its negative correlation with stock prices.

The evidence of a positive intertemporal relation between the mean and variance of market returns supports the basic prediction of several asset pricing models (e.g., Merton 
(1973), Campbell (1993)). In addition, this relation has important practical implications for financial decision makers. For example, the joint dynamics of the conditional mean and variance play a crucial role in dynamic portfolio selection (e.g., Campbell and Viceira (2002)). Also, since second moments of returns are generally easier to measure than first moments, imposing a positive mean-variance relation a priori may improve the first moment estimates by incorporating the sample information about the second moments (e.g., Pástor and Stambaugh (2001)). Further implications of the intertemporal mean-variance relation for inference and decision making can be examined in future work.

Future work can also examine other applications of the implied cost of capital. While the cross-section of the implied costs of capital has already been analyzed to some extent, both domestically (e.g., Gebhardt, Lee, and Swaminathan (2001) and Brav, Lehavy, and Michaely (2003)) and internationally (Lee, Ng, and Swaminathan (2003)), our results suggest that the implied cost of capital can also be useful in capturing the time variation in expected returns. Given the recent growth in the literature on time-varying expected returns, the implied cost of capital is likely to find new applications in the near future. 
Panel A. USA: Implied Market Risk Premium

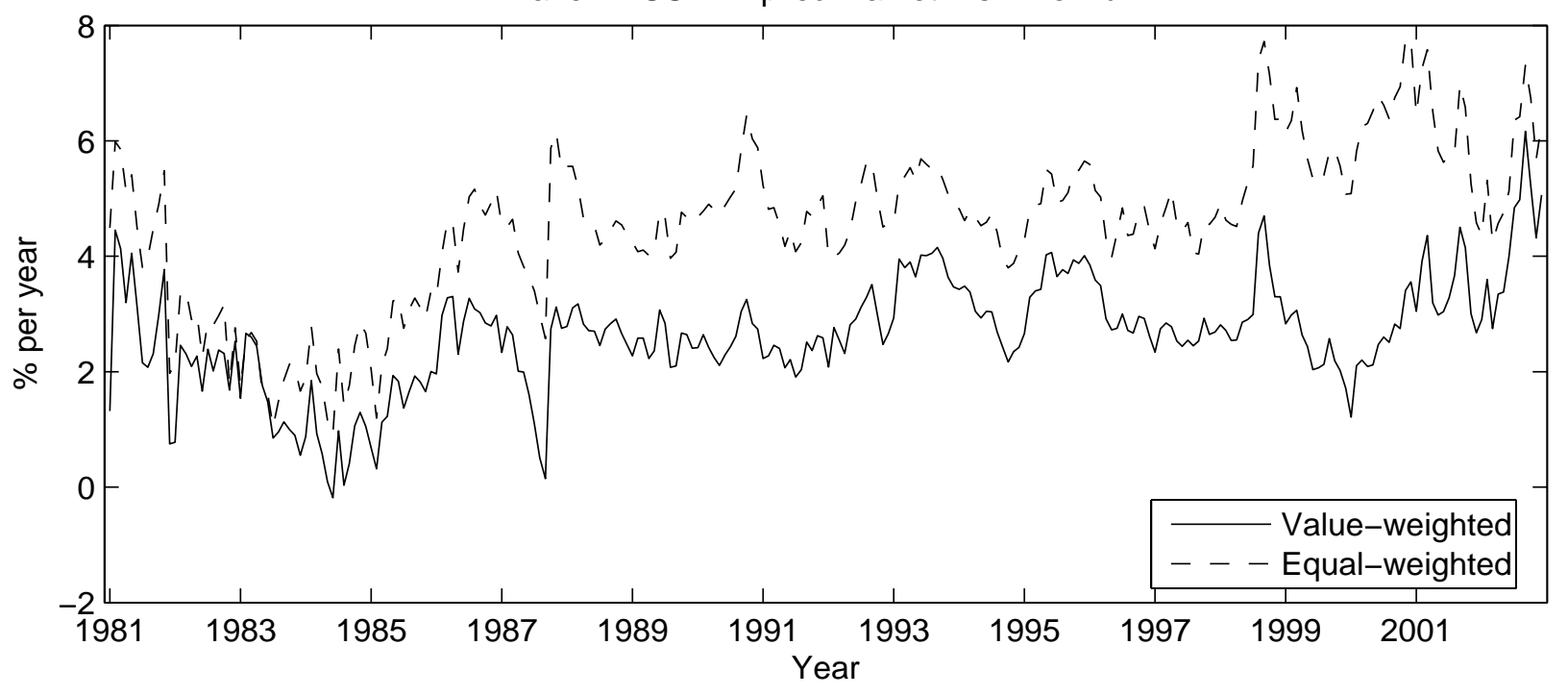

Panel B. USA: Market Return Volatility

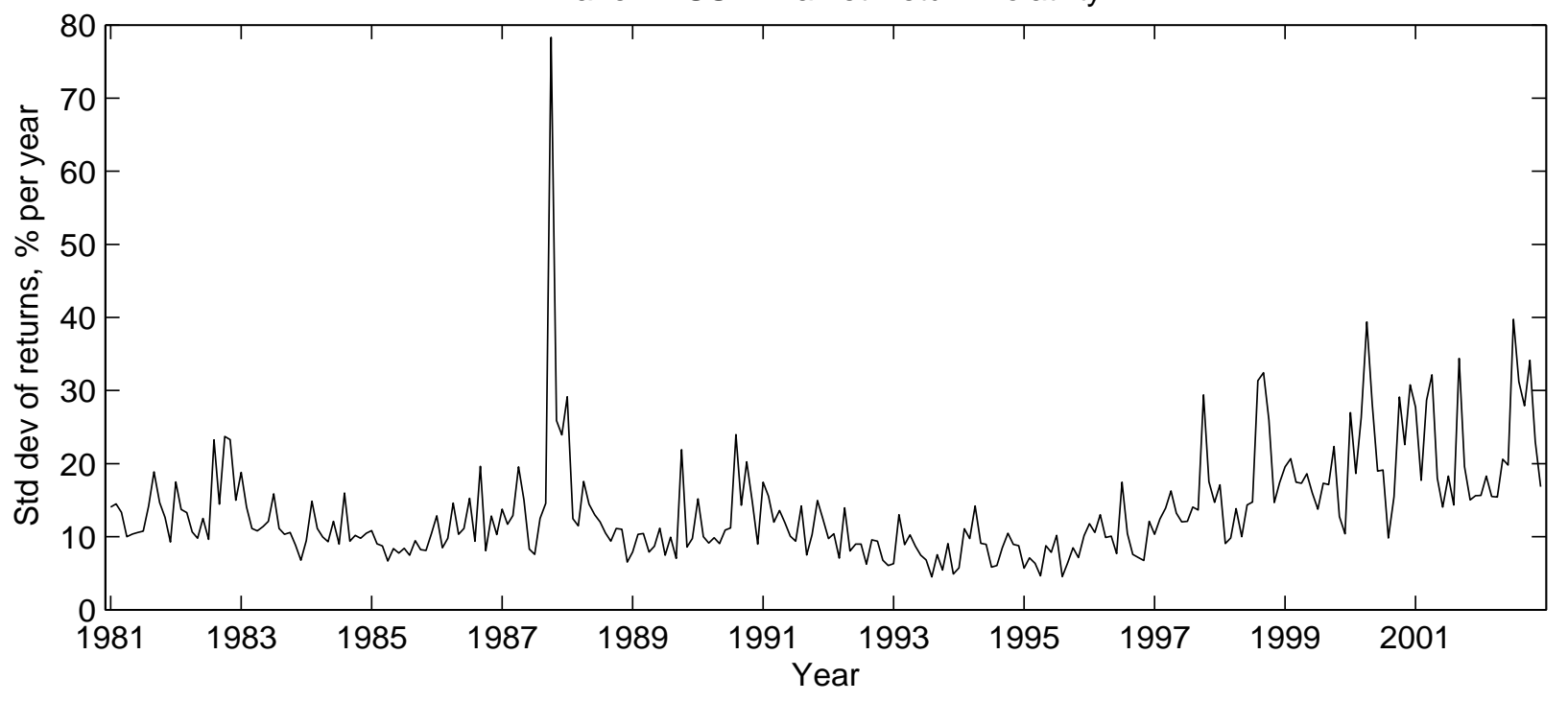

Figure 1. USA: Implied Market Risk Premium and Market Return Volatility. Panel A plots the monthly time series of the implied market risk premium for the U.S., computed as the difference between the implied cost of capital and the yield to maturity on the 10-year Treasury bond. The implied cost of capital is computed as an equal-weighted (dashed line) or value-weighted (solid line) average of the implied costs of capital across all U.S. firms. Panel B plots the monthly time series of the realized market return volatility, computed from daily data within the month. 
A. Canada: Implied Market Risk Premium

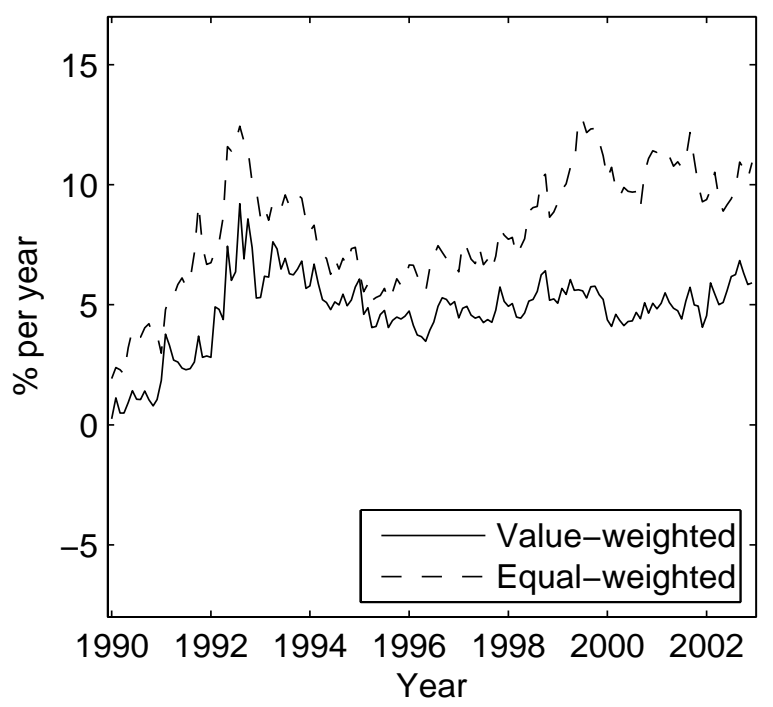

C. Canada: Market Return Volatility

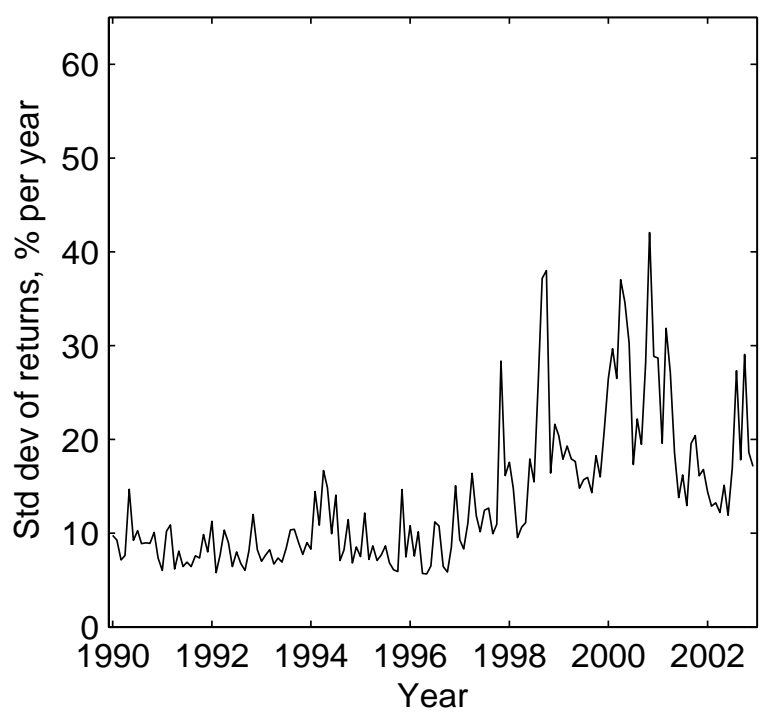

B. France: Implied Market Risk Premium

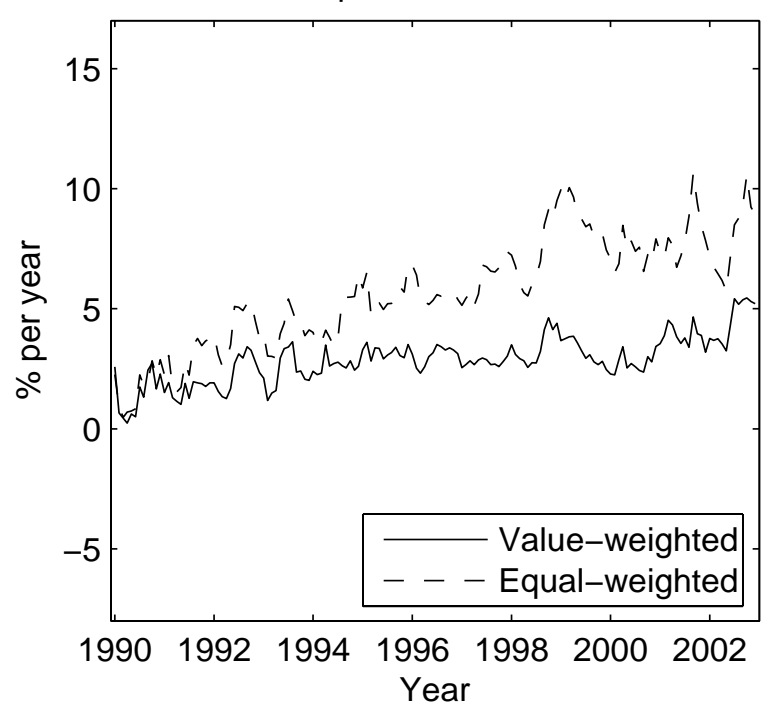

D. France: Market Return Volatility

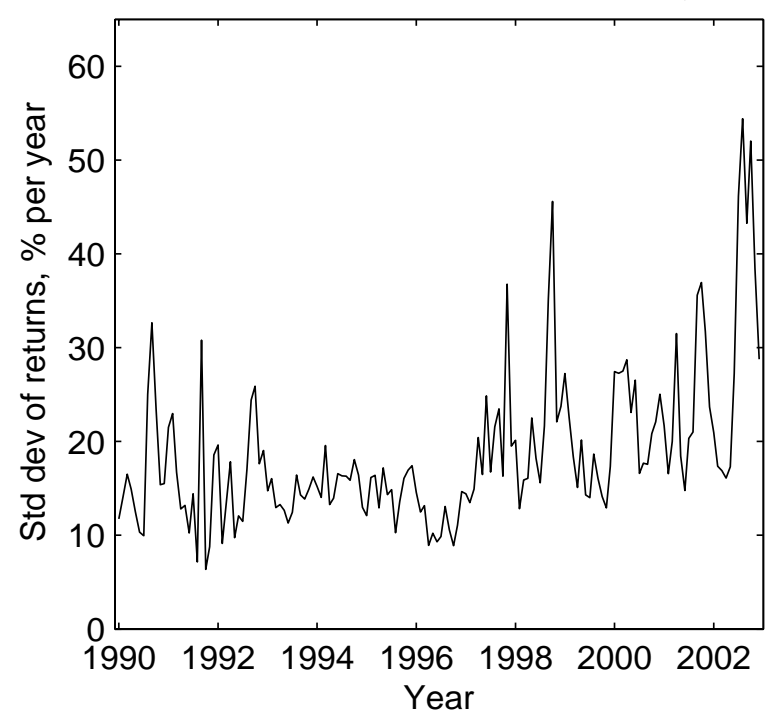

Figure 2. Canada and France: Implied Market Risk Premium and Market Return Volatility. Panels A and B plot the monthly time series of the implied market risk premium for Canada and France, respectively, computed as the difference between the implied cost of capital and the yield to maturity on the 10-year local government bond. The implied cost of capital is computed as an equal-weighted (dashed line) or value-weighted (solid line) average of the implied costs of capital across all firms in the given country. Panels $\mathrm{C}$ and $\mathrm{D}$ plot the monthly time series of the realized market return volatility, computed from daily data within the month. 
A. Germany: Implied Market Risk Premium

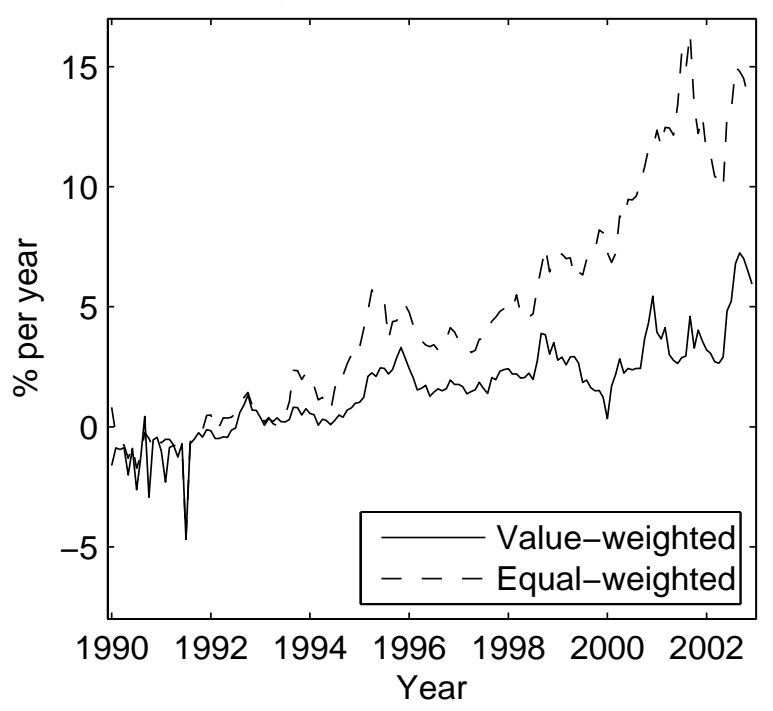

C. Germany: Market Return Volatility

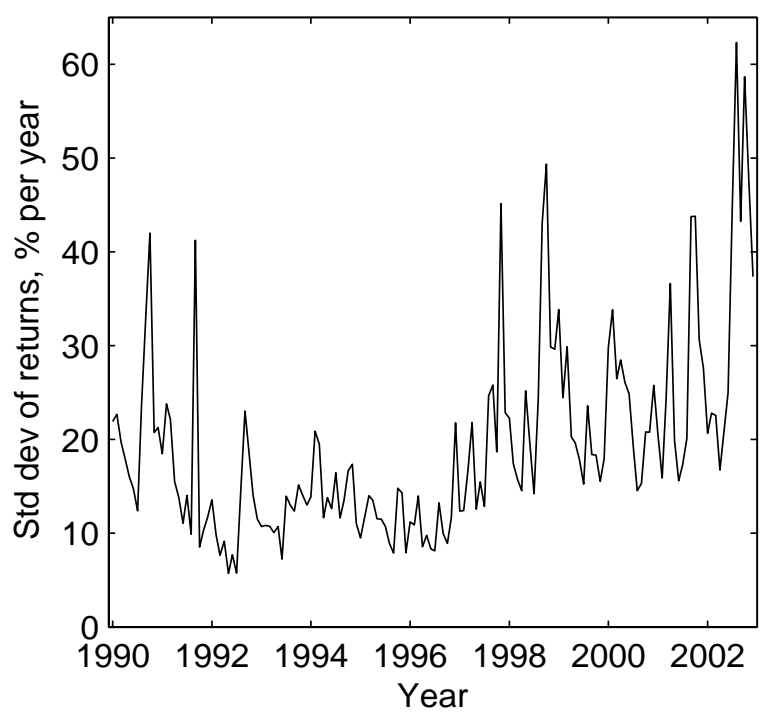

B. Italy: Implied Market Risk Premium
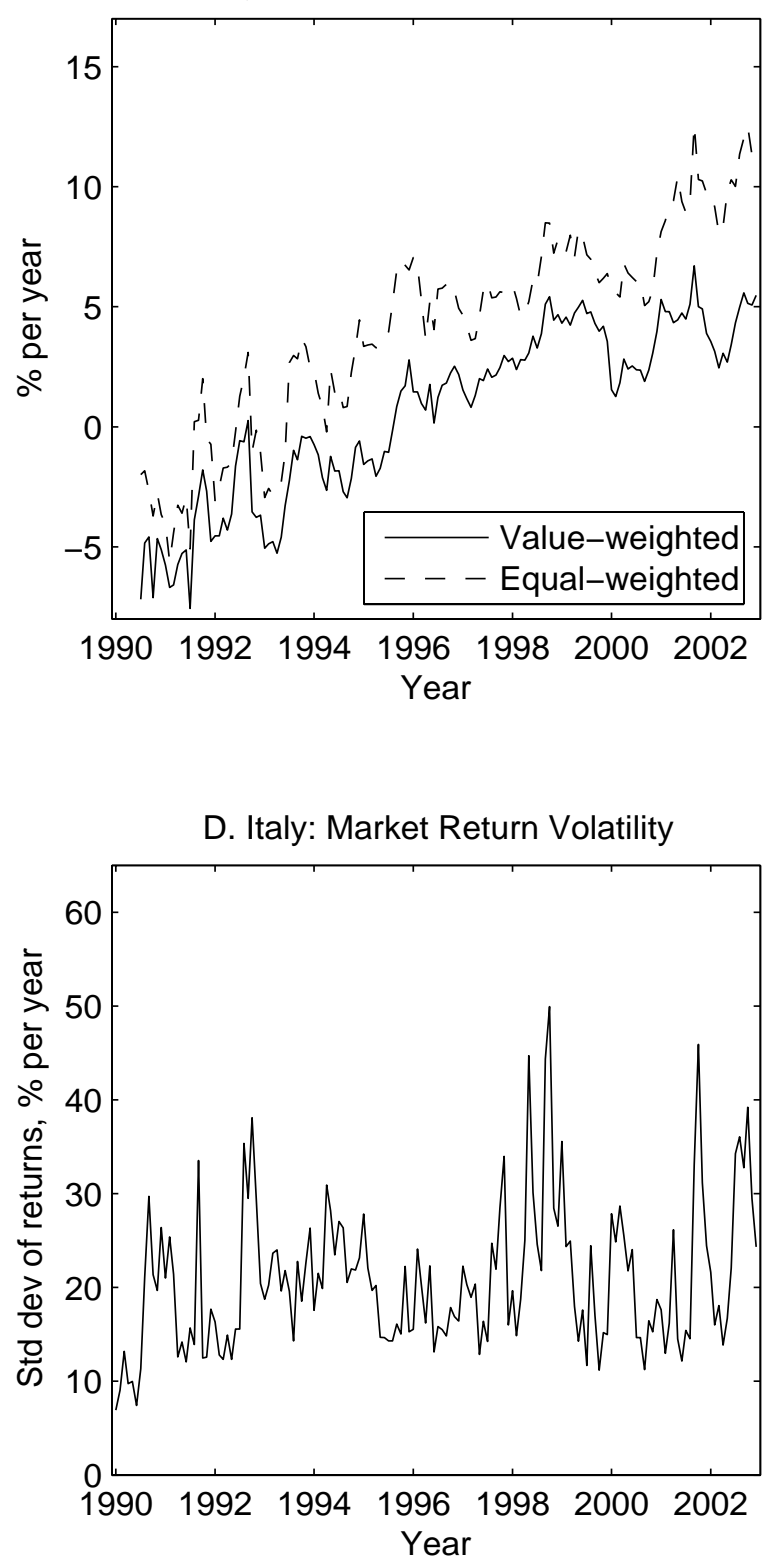

Figure 3. Germany and Italy: Implied Market Risk Premium and Market Return Volatility. Panels A and B plot the monthly time series of the implied market risk premium for Germany and Italy, respectively, computed as the difference between the implied cost of capital and the yield to maturity on the 10-year (Germany) or 7-year (Italy) local government bond. The implied cost of capital is computed as an equal-weighted (dashed line) or valueweighted (solid line) average of the implied costs of capital across all firms in the given country. Panels $\mathrm{C}$ and D plot the monthly time series of the realized market return volatility, computed from daily data within the month. 
A. Japan: Implied Market Risk Premium

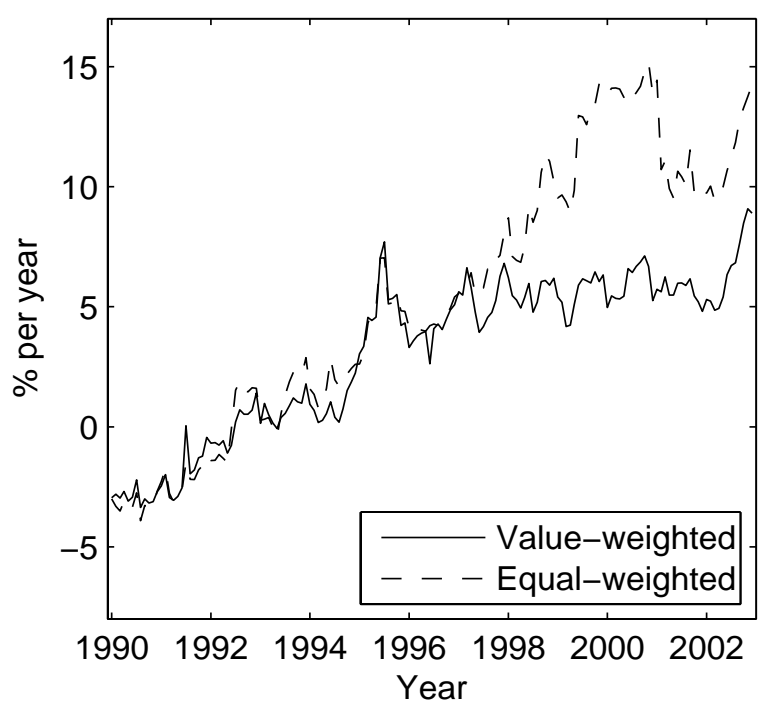

C. Japan: Market Return Volatility

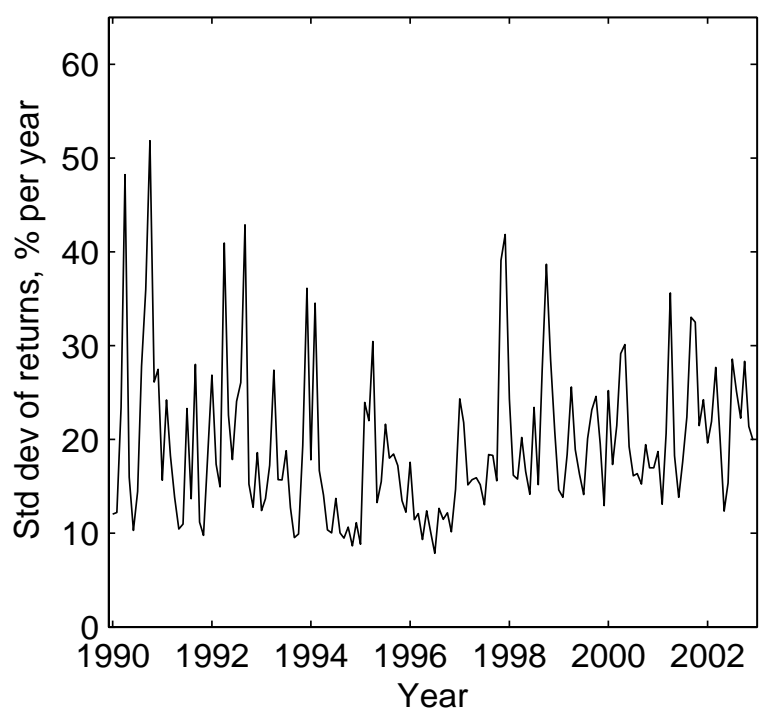

B. UK: Implied Market Risk Premium

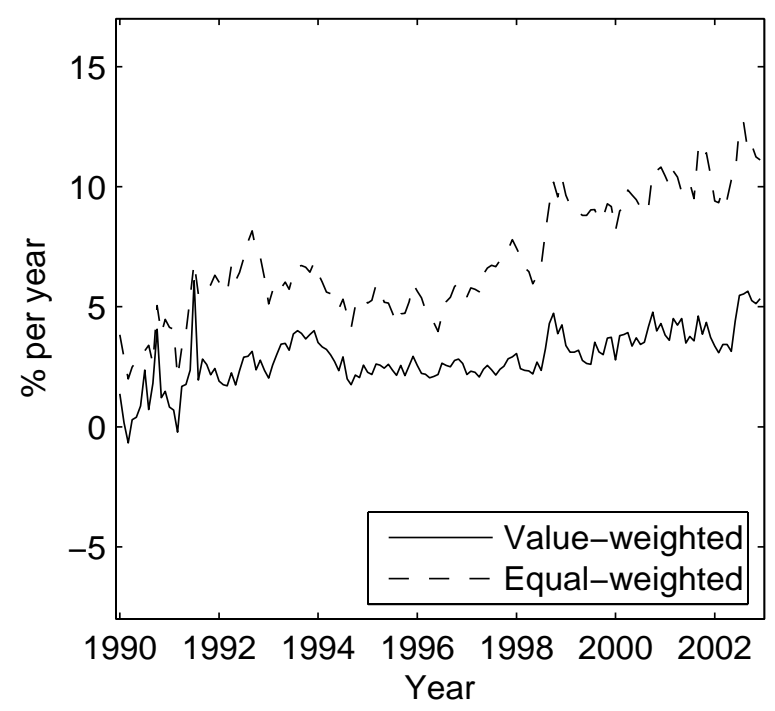

D. UK: Market Return Volatility

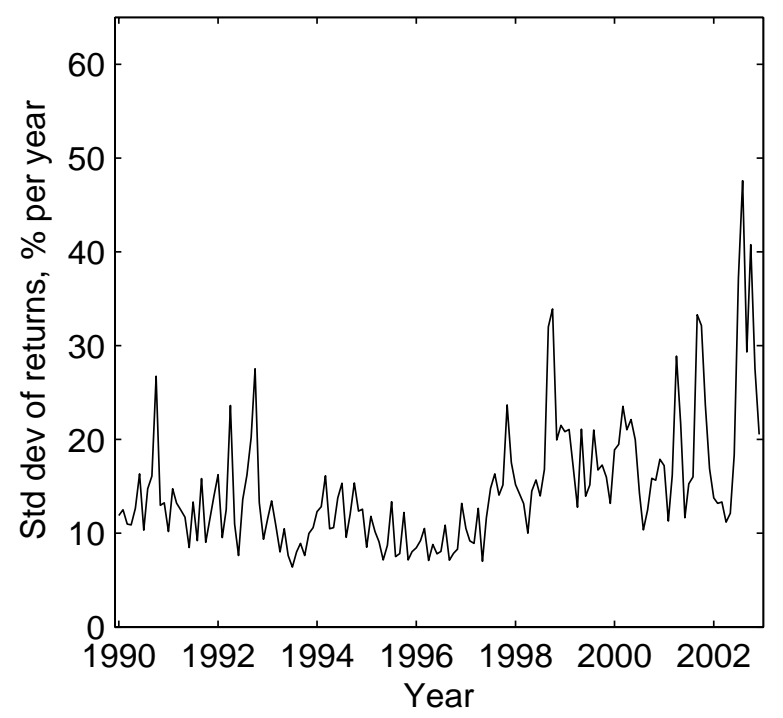

Figure 4. Japan and the United Kingdom: Implied Market Risk Premium and Market Return Volatility. Panels A and B plot the monthly time series of the implied market risk premium for Japan and the U.K., respectively, computed as the difference between the implied cost of capital and the yield to maturity on the 10-year local government bond. The implied cost of capital is computed as an equal-weighted (dashed line) or value-weighted (solid line) average of the implied costs of capital across all firms in the given country. Panels $\mathrm{C}$ and $\mathrm{D}$ plot the monthly time series of the realized market return volatility, computed from daily data within the month. 
Table 1

Simulation Evidence:

\section{Correlations Between Return Variance and Proxies for Expected Return}

This table reports the time-series correlations between the return variance $\sigma_{t}^{2}$ and three proxies for expected return $\mu_{t}$ : the implied cost of capital $\left(r_{e_{t}}\right)$, the implied cost of capital with unknown conditional expected cash flow $\left(r_{e 2_{t}}\right)$, and realized return $r_{t+1}$. Each correlation is computed by averaging the estimated correlations across 5,000 simulations. The $t$-statistics, reported in parentheses, are computed by dividing the corresponding average correlation by the standard deviation of the 5,000 correlations. The degree of the mean-variance link is the fraction of the conditional variance of $\sigma_{t}^{2}$ that can be explained by the conditional variance of $\mu_{t}$, or $\sigma_{u}^{2} /\left(\sigma_{u}^{2}+\sigma_{e}^{2}\right)$. The variable $\phi$ denotes the average fraction of the return variance that can be explained by the variation in expected return, or the unconditional mean of $\rho^{2} \sigma_{u}^{2} /\left((1-\rho \beta)^{2} \sigma_{t}^{2}\right)$. The length of the sample period over which the correlations are computed is denoted by $T$.

\begin{tabular}{|c|c|c|c|c|c|c|c|c|c|c|c|c|c|c|c|}
\hline \multirow[b]{3}{*}{$\phi$} & \multicolumn{12}{|c|}{ Degree of mean-variance link } & & & \\
\hline & \multicolumn{3}{|c|}{0.1} & \multicolumn{3}{|c|}{0.3} & \multicolumn{3}{|c|}{0.5} & \multicolumn{3}{|c|}{0.7} & \multicolumn{3}{|c|}{0.9} \\
\hline & $r_{e_{t}}$ & $r_{e 2} t$ & $r_{t+1}$ & $r_{e_{t}}$ & $r_{e 2 t}$ & $r_{t+1}$ & $r_{e_{t}}$ & $r_{e 2 t}$ & $r_{t+1}$ & $r_{e_{t}}$ & $r_{e 2_{t}}$ & $r_{t+1}$ & $r_{e_{t}}$ & $r_{e 2} t$ & $r_{t+1}$ \\
\hline & \multicolumn{15}{|c|}{$T=60$ months } \\
\hline 0.1 & $\begin{array}{c}0.34 \\
(2.70)\end{array}$ & $\begin{array}{c}0.11 \\
(0.71)\end{array}$ & $\begin{array}{c}0.03 \\
(0.17)\end{array}$ & $\begin{array}{c}0.62 \\
(6.16)\end{array}$ & $\begin{array}{c}0.22 \\
(1.20)\end{array}$ & $\begin{array}{c}0.06 \\
(0.41)\end{array}$ & $\begin{array}{c}0.78 \\
(11.25)\end{array}$ & $\begin{array}{c}0.28 \\
(1.39)\end{array}$ & $\begin{array}{c}0.08 \\
(0.57)\end{array}$ & $\begin{array}{c}0.89 \\
(22.74)\end{array}$ & $\begin{array}{c}0.31 \\
(1.47)\end{array}$ & $\begin{array}{c}0.10 \\
(0.70)\end{array}$ & $\begin{array}{c}0.97 \\
(78.49)\end{array}$ & $\begin{array}{c}0.32 \\
(1.47)\end{array}$ & $\begin{array}{c}0.11 \\
(0.82)\end{array}$ \\
\hline 0.3 & $\begin{array}{c}0.32 \\
(2.52)\end{array}$ & $\begin{array}{c}0.13 \\
(0.94)\end{array}$ & $\begin{array}{c}0.04 \\
(0.22)\end{array}$ & $\begin{array}{c}0.57 \\
(4.99)\end{array}$ & $\begin{array}{c}0.28 \\
(1.69)\end{array}$ & $\begin{array}{c}0.08 \\
(0.52)\end{array}$ & $\begin{array}{c}0.73 \\
(8.26)\end{array}$ & $\begin{array}{c}0.36 \\
(2.02)\end{array}$ & $\begin{array}{c}0.12 \\
(0.77)\end{array}$ & $\begin{array}{c}0.85 \\
(15.77)\end{array}$ & $\begin{array}{c}0.41 \\
(2.21)\end{array}$ & $\begin{array}{c}0.15 \\
(0.98)\end{array}$ & $\begin{array}{c}0.95 \\
(53.56)\end{array}$ & $\begin{array}{c}0.42 \\
(2.17)\end{array}$ & $\begin{array}{c}0.17 \\
(1.20)\end{array}$ \\
\hline 0.5 & $\begin{array}{c}0.31 \\
(2.40)\end{array}$ & $\begin{array}{c}0.15 \\
(1.03)\end{array}$ & $\begin{array}{c}0.04 \\
(0.26)\end{array}$ & $\begin{array}{c}0.54 \\
(4.56)\end{array}$ & $\begin{array}{c}0.30 \\
(1.90)\end{array}$ & $\begin{array}{c}0.09 \\
(0.59)\end{array}$ & $\begin{array}{c}0.70 \\
(7.36)\end{array}$ & $\begin{array}{c}0.39 \\
(2.35)\end{array}$ & $\begin{array}{c}0.14 \\
(0.87)\end{array}$ & $\begin{array}{c}0.84 \\
(13.49)\end{array}$ & $\begin{array}{c}0.45 \\
(2.61)\end{array}$ & $\begin{array}{c}0.17 \\
(1.15)\end{array}$ & $\begin{array}{c}0.95 \\
(46.40)\end{array}$ & $\begin{array}{c}0.47 \\
(2.58)\end{array}$ & $\begin{array}{c}0.21 \\
(1.42)\end{array}$ \\
\hline 0.7 & $\begin{array}{c}0.30 \\
(2.36)\end{array}$ & $\begin{array}{c}0.15 \\
(1.11)\end{array}$ & $\begin{array}{c}0.04 \\
(0.27)\end{array}$ & $\begin{array}{c}0.53 \\
(4.30)\end{array}$ & $\begin{array}{c}0.31 \\
(2.02)\end{array}$ & $\begin{array}{c}0.10 \\
(0.63)\end{array}$ & $\begin{array}{c}0.69 \\
(6.83)\end{array}$ & $\begin{array}{c}0.41 \\
(2.57)\end{array}$ & $\begin{array}{c}0.15 \\
(0.95)\end{array}$ & $\begin{array}{c}0.82 \\
(12.42)\end{array}$ & $\begin{array}{c}0.47 \\
(2.87)\end{array}$ & $\begin{array}{c}0.19 \\
(1.24)\end{array}$ & $\begin{array}{c}0.94 \\
(43.04)\end{array}$ & $\begin{array}{c}0.50 \\
(2.89)\end{array}$ & $\begin{array}{c}0.23 \\
(1.58)\end{array}$ \\
\hline \multirow[t]{2}{*}{0.9} & $\begin{array}{c}(2.50) \\
0.29 \\
(2.30)\end{array}$ & $\begin{array}{c}(1.11) \\
0.16 \\
(1.15)\end{array}$ & $\begin{array}{c}0.04 \\
(0.27)\end{array}$ & $\begin{array}{c}(4.50) \\
(4.14)\end{array}$ & $\begin{array}{c}(2.02) \\
0.32 \\
(2.09)\end{array}$ & $\begin{array}{c}(0.05) \\
0.11 \\
(0.68)\end{array}$ & $\begin{array}{c}0.68 \\
(6.44)\end{array}$ & $\begin{array}{c}0.42 \\
(2.73)\end{array}$ & $\begin{array}{c}(0.15) \\
(0.99)\end{array}$ & $\begin{array}{c}0.82 \\
(11.80)\end{array}$ & $\begin{array}{c}0.49 \\
(3.05)\end{array}$ & $\begin{array}{c}(1.24) \\
0.20 \\
(1.33)\end{array}$ & $\begin{array}{c}0.94 \\
(39.97)\end{array}$ & $\begin{array}{c}(2.05) \\
0.53 \\
(3.18)\end{array}$ & $\begin{array}{c}0.24 \\
(1.69)\end{array}$ \\
\hline & \multicolumn{15}{|c|}{$T=120$ months } \\
\hline 0.1 & $\begin{array}{c}0.36 \\
(4.02)\end{array}$ & $\begin{array}{c}0.11 \\
(1.00)\end{array}$ & $\begin{array}{c}0.03 \\
(0.28)\end{array}$ & $\begin{array}{c}0.64 \\
(9.05)\end{array}$ & $\begin{array}{c}0.22 \\
(1.61)\end{array}$ & $\begin{array}{c}0.06 \\
(0.59)\end{array}$ & $\begin{array}{c}0.80 \\
(17.04)\end{array}$ & $\begin{array}{c}0.28 \\
(1.85)\end{array}$ & $\begin{array}{c}0.08 \\
(0.79)\end{array}$ & $\begin{array}{c}0.90 \\
(34.63)\end{array}$ & $\begin{array}{c}0.31 \\
(1.93)\end{array}$ & $\begin{array}{c}0.10 \\
(0.96)\end{array}$ & $\begin{array}{c}0.97 \\
(119.31)\end{array}$ & $\begin{array}{c}0.32 \\
(1.93)\end{array}$ & $\begin{array}{c}0.11 \\
(1.09)\end{array}$ \\
\hline 0.3 & $\begin{array}{c}0.33 \\
(3.62)\end{array}$ & $\begin{array}{c}0.14 \\
(1.29)\end{array}$ & $\begin{array}{c}0.04 \\
(0.36)\end{array}$ & $\begin{array}{c}0.59 \\
(7.50)\end{array}$ & $\begin{array}{c}0.28 \\
(2.27)\end{array}$ & $\begin{array}{c}0.09 \\
(0.76)\end{array}$ & $\begin{array}{c}0.75 \\
(12.48)\end{array}$ & $\begin{array}{c}0.36 \\
(2.66)\end{array}$ & $\begin{array}{c}0.12 \\
(1.07)\end{array}$ & $\begin{array}{c}0.87 \\
(24.25)\end{array}$ & $\begin{array}{c}0.41 \\
(2.81)\end{array}$ & $\begin{array}{c}0.15 \\
(1.33)\end{array}$ & $\begin{array}{c}0.96 \\
(81.74)\end{array}$ & $\begin{array}{c}0.42 \\
(2.82)\end{array}$ & $\begin{array}{c}0.17 \\
(1.62)\end{array}$ \\
\hline 0.5 & $\begin{array}{c}0.32 \\
(3.58)\end{array}$ & $\begin{array}{c}0.15 \\
(1.48)\end{array}$ & $\begin{array}{c}0.04 \\
(0.39)\end{array}$ & $\begin{array}{c}0.56 \\
(6.69)\end{array}$ & $\begin{array}{c}0.31 \\
(2.56)\end{array}$ & $\begin{array}{c}0.10 \\
(0.86)\end{array}$ & $\begin{array}{c}0.72 \\
(11.05)\end{array}$ & $\begin{array}{c}0.40 \\
(3.08)\end{array}$ & $\begin{array}{c}0.14 \\
(1.22)\end{array}$ & $\begin{array}{c}0.85 \\
(20.78)\end{array}$ & $\begin{array}{c}0.45 \\
(3.33)\end{array}$ & $\begin{array}{c}0.17 \\
(1.55)\end{array}$ & $\begin{array}{c}0.95 \\
(70.57)\end{array}$ & $\begin{array}{c}0.46 \\
(3.32)\end{array}$ & $\begin{array}{c}0.20 \\
(1.90)\end{array}$ \\
\hline 0.7 & $\begin{array}{c}0.31 \\
(3.44)\end{array}$ & $\begin{array}{c}0.16 \\
(1.56)\end{array}$ & $\begin{array}{c}0.05 \\
(0.42)\end{array}$ & $\begin{array}{c}0.55 \\
(6.40)\end{array}$ & $\begin{array}{c}0.32 \\
(2.78)\end{array}$ & $\begin{array}{c}0.10 \\
(0.91)\end{array}$ & $\begin{array}{c}0.71 \\
(10.24)\end{array}$ & $\begin{array}{c}0.42 \\
(3.36)\end{array}$ & $\begin{array}{c}0.15 \\
(1.31)\end{array}$ & $\begin{array}{c}0.84 \\
(19.19)\end{array}$ & $\begin{array}{c}0.47 \\
(3.67)\end{array}$ & $\begin{array}{c}0.19 \\
(1.70)\end{array}$ & $\begin{array}{c}0.95 \\
(63.77)\end{array}$ & $\begin{array}{c}0.49 \\
(3.74)\end{array}$ & $\begin{array}{c}0.22 \\
(2.09)\end{array}$ \\
\hline 0.9 & $\begin{array}{c}0.31 \\
(3.35)\end{array}$ & $\begin{array}{c}0.17 \\
(1.62)\end{array}$ & $\begin{array}{c}0.05 \\
(0.46)\end{array}$ & $\begin{array}{c}0.54 \\
(6.08)\end{array}$ & $\begin{array}{c}0.33 \\
(2.90)\end{array}$ & $\begin{array}{c}0.11 \\
(0.97)\end{array}$ & $\begin{array}{c}0.70 \\
(9.75)\end{array}$ & $\begin{array}{c}0.43 \\
(3.56)\end{array}$ & $\begin{array}{c}0.15 \\
(1.39)\end{array}$ & $\begin{array}{c}0.83 \\
(18.14)\end{array}$ & $\begin{array}{c}0.49 \\
(3.95)\end{array}$ & $\begin{array}{c}0.20 \\
(1.80)\end{array}$ & $\begin{array}{c}0.95 \\
(60.47)\end{array}$ & $\begin{array}{c}0.52 \\
(4.06)\end{array}$ & $\begin{array}{c}0.24 \\
(2.27)\end{array}$ \\
\hline & \multicolumn{15}{|c|}{$T=240$ months } \\
\hline 0.1 & $\begin{array}{c}0.37 \\
(5.80)\end{array}$ & $\begin{array}{c}0.11 \\
(1.48)\end{array}$ & $\begin{array}{c}0.03 \\
(0.40)\end{array}$ & $\begin{array}{c}0.65 \\
(13.14)\end{array}$ & $\begin{array}{c}0.23 \\
(2.33)\end{array}$ & $\begin{array}{c}0.06 \\
(0.84)\end{array}$ & $\begin{array}{c}0.81 \\
(24.86)\end{array}$ & $\begin{array}{c}0.29 \\
(2.61)\end{array}$ & $\begin{array}{c}0.08 \\
(1.12)\end{array}$ & $\begin{array}{c}0.90 \\
(51.25)\end{array}$ & $\begin{array}{c}0.31 \\
(2.70)\end{array}$ & $\begin{array}{c}0.10 \\
(1.32)\end{array}$ & $\begin{array}{c}0.97 \\
(175.12)\end{array}$ & $\begin{array}{c}0.32 \\
(2.69)\end{array}$ & $\begin{array}{c}0.11 \\
(1.49)\end{array}$ \\
\hline 0.3 & $\begin{array}{c}0.34 \\
(5.22)\end{array}$ & $\begin{array}{c}0.14 \\
(1.92)\end{array}$ & $\begin{array}{c}0.04 \\
(0.49)\end{array}$ & $\begin{array}{c}0.60 \\
(10.58)\end{array}$ & $\begin{array}{c}0.29 \\
(3.25)\end{array}$ & $\begin{array}{c}0.09 \\
(1.07)\end{array}$ & $\begin{array}{c}0.76 \\
(18.20)\end{array}$ & $\begin{array}{c}0.37 \\
(3.74)\end{array}$ & $\begin{array}{c}0.12 \\
(1.49)\end{array}$ & $\begin{array}{c}0.87 \\
(34.74)\end{array}$ & $\begin{array}{c}0.41 \\
(3.90)\end{array}$ & $\begin{array}{c}0.14 \\
(1.82)\end{array}$ & $\begin{array}{c}0.96 \\
(118.25)\end{array}$ & $\begin{array}{c}0.42 \\
(3.83)\end{array}$ & $\begin{array}{c}0.17 \\
(2.19)\end{array}$ \\
\hline 0.5 & $\begin{array}{c}0.33 \\
(5.08)\end{array}$ & $\begin{array}{c}0.16 \\
(2.15)\end{array}$ & $\begin{array}{c}0.04 \\
(0.54)\end{array}$ & $\begin{array}{c}0.58 \\
(9.69)\end{array}$ & $\begin{array}{c}0.32 \\
(3.71)\end{array}$ & $\begin{array}{c}0.10 \\
(1.20)\end{array}$ & $\begin{array}{c}0.74 \\
(15.78)\end{array}$ & $\begin{array}{c}0.40 \\
(4.33)\end{array}$ & $\begin{array}{c}0.14 \\
(1.69)\end{array}$ & $\begin{array}{c}0.86 \\
(30.01)\end{array}$ & $\begin{array}{c}0.45 \\
(4.57)\end{array}$ & $\begin{array}{c}0.17 \\
(2.11)\end{array}$ & $\begin{array}{c}0.96 \\
(101.50)\end{array}$ & $\begin{array}{c}0.46 \\
(4.55)\end{array}$ & $\begin{array}{c}0.20 \\
(2.56)\end{array}$ \\
\hline 0.7 & $\begin{array}{c}0.32 \\
(5.00)\end{array}$ & $\begin{array}{c}0.17 \\
(2.30)\end{array}$ & $\begin{array}{c}0.05 \\
(0.57)\end{array}$ & $\begin{array}{c}0.56 \\
(9.24)\end{array}$ & $\begin{array}{c}0.33 \\
(4.00)\end{array}$ & $\begin{array}{c}0.10 \\
(1.27)\end{array}$ & $\begin{array}{c}0.72 \\
(14.56)\end{array}$ & $\begin{array}{c}0.42 \\
(4.67)\end{array}$ & $\begin{array}{c}0.15 \\
(1.82)\end{array}$ & $\begin{array}{c}0.85 \\
(27.51)\end{array}$ & $\begin{array}{l}0.48 \\
(5.07)\end{array}$ & $\begin{array}{c}0.18 \\
(2.30)\end{array}$ & $\begin{array}{c}0.95 \\
(93.42)\end{array}$ & $\begin{array}{c}0.49 \\
(5.07)\end{array}$ & $\begin{array}{c}0.21 \\
(2.82)\end{array}$ \\
\hline 0.9 & $\begin{array}{c}0.32 \\
(4.90)\end{array}$ & $\begin{array}{c}0.17 \\
(2.37)\end{array}$ & $\begin{array}{c}0.05 \\
(0.59)\end{array}$ & $\begin{array}{c}0.55 \\
(8.63)\end{array}$ & $\begin{array}{c}0.34 \\
(4.18)\end{array}$ & $\begin{array}{c}0.11 \\
(1.34)\end{array}$ & $\begin{array}{c}0.71 \\
(13.88)\end{array}$ & $\begin{array}{c}0.43 \\
(4.99)\end{array}$ & $\begin{array}{c}0.15 \\
(1.92)\end{array}$ & $\begin{array}{c}0.84 \\
(25.71)\end{array}$ & $\begin{array}{l}0.49 \\
(5.48)\end{array}$ & $\begin{array}{c}0.19 \\
(2.46)\end{array}$ & $\begin{array}{c}0.95 \\
(86.47)\end{array}$ & $\begin{array}{c}0.51 \\
(5.54)\end{array}$ & $\begin{array}{c}0.23 \\
(3.05)\end{array}$ \\
\hline & \multicolumn{15}{|c|}{$T=360$ months } \\
\hline 0.1 & $\begin{array}{c}0.37 \\
(7.19)\end{array}$ & $\begin{array}{c}0.11 \\
(1.76)\end{array}$ & $\begin{array}{c}0.03 \\
(0.51)\end{array}$ & $\begin{array}{c}0.65 \\
(16.27)\end{array}$ & $\begin{array}{c}0.23 \\
(2.80)\end{array}$ & $\begin{array}{c}0.07 \\
(1.06)\end{array}$ & $\begin{array}{c}0.81 \\
(30.83)\end{array}$ & $\begin{array}{c}0.28 \\
(3.13)\end{array}$ & $\begin{array}{c}0.08 \\
(1.40)\end{array}$ & $\begin{array}{c}0.90 \\
(63.04)\end{array}$ & $\begin{array}{c}0.31 \\
(3.23)\end{array}$ & $\begin{array}{c}0.10 \\
(1.64)\end{array}$ & $\begin{array}{c}0.97 \\
(217.55)\end{array}$ & $\begin{array}{c}0.32 \\
(3.21)\end{array}$ & $\begin{array}{c}0.11 \\
(1.86)\end{array}$ \\
\hline 0.3 & $\begin{array}{c}0.34 \\
(6.63)\end{array}$ & $\begin{array}{c}0.14 \\
(2.29)\end{array}$ & $\begin{array}{c}0.04 \\
(0.63)\end{array}$ & $\begin{array}{c}0.60 \\
(13.11)\end{array}$ & $\begin{array}{c}0.29 \\
(3.89)\end{array}$ & $\begin{array}{c}0.09 \\
(1.35)\end{array}$ & $\begin{array}{c}0.76 \\
(22.68)\end{array}$ & $\begin{array}{c}0.37 \\
(4.48)\end{array}$ & $\begin{array}{c}0.12 \\
(1.85)\end{array}$ & $\begin{array}{c}0.87 \\
(43.89)\end{array}$ & $\begin{array}{c}0.41 \\
(4.68)\end{array}$ & $\begin{array}{c}0.14 \\
(2.27)\end{array}$ & $\begin{array}{c}0.96 \\
(147.96)\end{array}$ & $\begin{array}{c}0.41 \\
(4.61)\end{array}$ & $\begin{array}{c}0.16 \\
(2.70)\end{array}$ \\
\hline 0.5 & $\begin{array}{c}0.33 \\
(6.30)\end{array}$ & $\begin{array}{c}0.16 \\
(2.54)\end{array}$ & $\begin{array}{c}0.05 \\
(0.70)\end{array}$ & $\begin{array}{c}0.58 \\
(11.92)\end{array}$ & $\begin{array}{c}0.32 \\
(4.41)\end{array}$ & $\begin{array}{c}0.10 \\
(1.48)\end{array}$ & $\begin{array}{c}0.74 \\
(19.90)\end{array}$ & $\begin{array}{c}(4.40 \\
0.40 \\
(5.17)\end{array}$ & $\begin{array}{c}0.14 \\
(2.08)\end{array}$ & $\begin{array}{c}0.86 \\
(38.10)\end{array}$ & $\begin{array}{l}0.45 \\
(5.51)\end{array}$ & $\begin{array}{c}0.17 \\
(2.61)\end{array}$ & $\begin{array}{c}0.96 \\
(127.15)\end{array}$ & $\begin{array}{c}0.46 \\
(5.44)\end{array}$ & $\begin{array}{c}0.19 \\
(3.18)\end{array}$ \\
\hline 0.7 & $\begin{array}{c}0.32 \\
(6.18)\end{array}$ & $\begin{array}{c}0.17 \\
(2.74)\end{array}$ & $\begin{array}{c}0.05 \\
(0.74)\end{array}$ & $\begin{array}{c}0.56 \\
(11.26)\end{array}$ & $\begin{array}{c}0.33 \\
(4.77)\end{array}$ & $\begin{array}{c}0.10 \\
(1.59)\end{array}$ & $\begin{array}{c}0.72 \\
(18.13)\end{array}$ & $\begin{array}{c}0.42 \\
(5.71)\end{array}$ & $\begin{array}{c}0.15 \\
(2.25)\end{array}$ & $\begin{array}{c}0.85 \\
(34.73)\end{array}$ & $\begin{array}{c}0.48 \\
(6.17)\end{array}$ & $\begin{array}{c}0.18 \\
(2.86)\end{array}$ & $\begin{array}{c}0.95 \\
(115.53)\end{array}$ & $\begin{array}{c}0.49 \\
(6.08)\end{array}$ & $\begin{array}{c}0.21 \\
(3.51)\end{array}$ \\
\hline 0.9 & $\begin{array}{c}0.32 \\
(6.03)\end{array}$ & $\begin{array}{c}0.17 \\
(2.85)\end{array}$ & $\begin{array}{c}0.05 \\
(0.76)\end{array}$ & $\begin{array}{c}0.55 \\
(10.76)\end{array}$ & $\begin{array}{c}0.34 \\
(5.00)\end{array}$ & $\begin{array}{c}0.11 \\
(1.65)\end{array}$ & $\begin{array}{c}0.71 \\
(17.15)\end{array}$ & $\begin{array}{c}0.43 \\
(6.01)\end{array}$ & $\begin{array}{c}0.15 \\
(2.39)\end{array}$ & $\begin{array}{c}0.84 \\
(32.31)\end{array}$ & $\begin{array}{c}0.49 \\
(6.67)\end{array}$ & $\begin{array}{c}0.19 \\
(3.03)\end{array}$ & $\begin{array}{c}0.95 \\
(108.20)\end{array}$ & $\begin{array}{c}0.51 \\
(6.60)\end{array}$ & $\begin{array}{c}0.23 \\
(3.76)\end{array}$ \\
\hline & \multicolumn{15}{|c|}{$T=600$ months } \\
\hline 0.1 & $\begin{array}{c}0.37 \\
(9.26)\end{array}$ & $\begin{array}{c}0.11 \\
(2.24)\end{array}$ & $\begin{array}{c}0.03 \\
(0.63)\end{array}$ & $\begin{array}{c}0.66 \\
(21.01)\end{array}$ & $\begin{array}{c}0.23 \\
(3.51)\end{array}$ & $\begin{array}{c}0.07 \\
(1.35)\end{array}$ & $\begin{array}{c}0.81 \\
(40.35)\end{array}$ & $\begin{array}{c}0.28 \\
(3.89)\end{array}$ & $\begin{array}{c}0.08 \\
(1.78)\end{array}$ & $\begin{array}{c}0.91 \\
(83.44)\end{array}$ & $\begin{array}{c}0.31 \\
(4.04)\end{array}$ & $\begin{array}{c}0.10 \\
(2.10)\end{array}$ & $\begin{array}{c}0.97 \\
(286.92)\end{array}$ & $\begin{array}{c}0.32 \\
(4.01)\end{array}$ & $\begin{array}{c}0.11 \\
(2.37)\end{array}$ \\
\hline 0.3 & $\begin{array}{c}0.34 \\
(8.49)\end{array}$ & $\begin{array}{c}0.14 \\
(2.95)\end{array}$ & $\begin{array}{c}0.04 \\
(0.77)\end{array}$ & $\begin{array}{c}0.61 \\
(17.09)\end{array}$ & $\begin{array}{c}(0.29) \\
0.29 \\
(4.90)\end{array}$ & $\begin{array}{c}0.09 \\
(1.70)\end{array}$ & $\begin{array}{c}0.76 \\
(29.27)\end{array}$ & $\begin{array}{c}0.37 \\
(5.64)\end{array}$ & $\begin{array}{c}0.12 \\
(2.36)\end{array}$ & $\begin{array}{c}0.88 \\
(57.38)\end{array}$ & $\begin{array}{c}0.41 \\
(5.86)\end{array}$ & $\begin{array}{c}0.14 \\
(2.89)\end{array}$ & $\begin{array}{c}0.96 \\
(195.66)\end{array}$ & $\begin{array}{c}0.41 \\
(5.78)\end{array}$ & $\begin{array}{c}0.16 \\
(3.44)\end{array}$ \\
\hline 0.5 & $\begin{array}{c}0.33 \\
(8.21)\end{array}$ & $\begin{array}{c}0.16 \\
(3.32)\end{array}$ & $\begin{array}{c}0.04 \\
(0.87)\end{array}$ & $\begin{array}{c}0.58 \\
(15.53)\end{array}$ & $\begin{array}{c}0.32 \\
(5.56)\end{array}$ & $\begin{array}{c}0.10 \\
(1.89)\end{array}$ & $\begin{array}{c}0.74 \\
(25.85)\end{array}$ & $\begin{array}{c}0.40 \\
(6.55)\end{array}$ & $\begin{array}{c}0.13 \\
(2.66)\end{array}$ & $\begin{array}{c}0.86 \\
(49.99)\end{array}$ & $\begin{array}{c}0.45 \\
(6.84)\end{array}$ & $\begin{array}{c}0.17 \\
(3.33)\end{array}$ & $\begin{array}{c}0.96 \\
(169.42)\end{array}$ & $\begin{array}{c}0.46 \\
(6.78)\end{array}$ & $\begin{array}{c}0.19 \\
(4.02)\end{array}$ \\
\hline 0.7 & $\begin{array}{c}0.33 \\
(7.97)\end{array}$ & $\begin{array}{c}0.17 \\
(3.51)\end{array}$ & $\begin{array}{c}0.05 \\
(0.94)\end{array}$ & $\begin{array}{c}0.57 \\
(14.57)\end{array}$ & $\begin{array}{c}0.33 \\
(6.02)\end{array}$ & $\begin{array}{c}0.10 \\
(2.00)\end{array}$ & $\begin{array}{c}0.73 \\
(23.65)\end{array}$ & $\begin{array}{c}0.42 \\
(7.12)\end{array}$ & $\begin{array}{c}0.15 \\
(2.89)\end{array}$ & $\begin{array}{c}0.85 \\
(45.42)\end{array}$ & $\begin{array}{c}0.47 \\
(7.53)\end{array}$ & $\begin{array}{c}0.18 \\
(3.63)\end{array}$ & $\begin{array}{c}0.95 \\
(152.87)\end{array}$ & $\begin{array}{c}0.49 \\
(7.58)\end{array}$ & $\begin{array}{c}0.21 \\
(4.43)\end{array}$ \\
\hline 0.9 & $\begin{array}{c}0.32 \\
(7.81)\end{array}$ & $\begin{array}{c}0.18 \\
(3.73)\end{array}$ & $\begin{array}{c}0.05 \\
(0.95)\end{array}$ & $\begin{array}{c}0.56 \\
(14.07)\end{array}$ & $\begin{array}{c}0.34 \\
(6.33)\end{array}$ & $\begin{array}{c}0.11 \\
(2.10)\end{array}$ & $\begin{array}{c}0.72 \\
(22.38)\end{array}$ & $\begin{array}{c}0.44 \\
(7.54)\end{array}$ & $\begin{array}{c}0.15 \\
(3.04)\end{array}$ & $\begin{array}{c}0.84 \\
(42.53)\end{array}$ & $\begin{array}{c}0.49 \\
(8.18)\end{array}$ & $\begin{array}{c}0.19 \\
(3.89)\end{array}$ & $\begin{array}{c}0.95 \\
(142.43)\end{array}$ & $\begin{array}{c}0.51 \\
(8.23)\end{array}$ & $\begin{array}{c}0.23 \\
(4.81)\end{array}$ \\
\hline
\end{tabular}


Table 2

Time-series Summary Statistics

The table contains the summary statistics for the implied risk premia and the return volatility for each of the G-7 countries. The statistics are computed over the period 1981-2002 for the United States and over 1990-2002 for the other countries (For Italy, the time series of implied risk premia starts in July 1990). The implied risk premia are computed as the difference between the cost of equity computed from a discounted cash flow model that uses analyst forecasts of earnings and the yield on the country's 10-year government bond (except for Italy, where we use the yield on the 7-year bond). Standard deviation of returns is the annualized standard deviation of the daily market returns computed over the previous month, where the 'market' is the CRSP value-weighted index for the United States and the MSCI index for other countries. Data for the United States is obtained from COMPUSTAT, CRSP and I/B/E/S. Data on other countries is obtained from Worldscope, Datastream and $\mathrm{I} / \mathrm{B} / \mathrm{E} / \mathrm{S}$. N is the average across months of the number of firms for which the implied cost of capital is available.

\begin{tabular}{|c|c|c|c|c|c|c|c|c|c|c|c|c|c|}
\hline \multirow[t]{2}{*}{ Country } & \multirow[b]{2}{*}{$\mathrm{N}$} & \multicolumn{4}{|c|}{ Equal-Weighted Risk Premia } & \multicolumn{4}{|c|}{ Value-Weighted Risk Premia } & \multicolumn{4}{|c|}{ Standard Deviation of Returns } \\
\hline & & Min & Mean & Max & Std. Dev. & Min & Mean & Max & Std. Dev. & Min & Mean & Max & Std. Dev. \\
\hline CANADA & 275 & 0.019 & 0.081 & 0.128 & 0.025 & 0.002 & 0.047 & 0.092 & 0.016 & 0.057 & 0.137 & 0.421 & 0.076 \\
\hline FRANCE & 308 & 0.005 & 0.057 & 0.106 & 0.023 & 0.002 & 0.029 & 0.055 & 0.010 & 0.064 & 0.188 & 0.544 & 0.083 \\
\hline GERMANY & 279 & -0.047 & 0.048 & 0.164 & 0.046 & -0.047 & 0.016 & 0.072 & 0.019 & 0.057 & 0.194 & 0.623 & 0.105 \\
\hline ITALY & 115 & -0.056 & 0.042 & 0.126 & 0.043 & -0.076 & 0.006 & 0.067 & 0.036 & 0.069 & 0.208 & 0.499 & 0.078 \\
\hline JAPAN & 960 & -0.039 & 0.054 & 0.152 & 0.056 & -0.034 & 0.031 & 0.091 & 0.033 & 0.079 & 0.194 & 0.519 & 0.082 \\
\hline UK & 787 & 0.020 & 0.070 & 0.127 & 0.024 & -0.007 & 0.029 & 0.061 & 0.011 & 0.064 & 0.148 & 0.476 & 0.069 \\
\hline USA & 1795 & 0.009 & 0.046 & 0.078 & 0.014 & -0.002 & 0.026 & 0.062 & 0.010 & 0.045 & 0.137 & 0.783 & 0.076 \\
\hline
\end{tabular}


Table 3

Predictive Regressions Involving Realized Excess Returns and Volatility

The table contains the results of time-series regressions using monthly data over the period 1981-2002 for the United States and over 1990-2002 for the other countries. $\mathrm{R}_{t}$ is the monthly excess return (in excess of the risk-free rate) on the CRSP value-weighted index for the United States, or the monthly excess return on the Morgan Stanley Country Index (MSCI) for the other G-7 countries. $\mathrm{R}_{\mathrm{f}}$ is the one-month risk-free rate. $\sigma_{\mathrm{t}}$ is the square root of 21 times the standard deviation of the daily returns on the market, computed over the previous month, where the 'market' is the CRSP value-weighted index for the United States and the MSCI index for other countries. Data for the United States are obtained from COMPUSTAT, CRSP and $\mathrm{I} / \mathrm{B} / \mathrm{E} / \mathrm{S}$. Data for other countries are obtained from Worldscope, Datastream and I/B/E/S. The numbers in parentheses are t-statistics computed using the Newey-West correction with 1 lag of autocorrelation and also corrected for heteroskedasticity.

\section{PANEL 1. CANADA}

\begin{tabular}{lcccccc}
\hline & Intercept & $\sigma_{\mathbf{t}}{ }^{2}$ & Adj. $\mathbf{R}^{2}$ & Intercept & $\sigma_{\mathbf{t}}$ & Adj. $\mathbf{R}^{\mathbf{2}}$ \\
\cline { 2 - 7 } $\mathbf{R}_{\mathbf{t}+1}-\mathbf{R}_{\mathrm{ft}+1}$ & 0.003 & 0.026 & $-0.65 \%$ & 0.002 & 0.024 & $-0.64 \%$ \\
& $(0.60)$ & $(0.01)$ & & $(0.22)$ & $(0.10)$ &
\end{tabular}

\section{PANEL 2. FRANCE}

\begin{tabular}{lcccccc}
\hline & Intercept & $\sigma_{\mathbf{t}}^{2}$ & Adj. $\mathbf{R}^{2}$ & Intercept & $\sigma_{\mathbf{t}}$ & Adj. $\mathbf{R}^{2}$ \\
\cline { 2 - 7 } $\mathbf{R}_{\mathbf{t}+1}-\mathbf{R}_{\mathrm{ft}+1}$ & 0.004 & -0.278 & $-0.62 \%$ & 0.005 & -0.039 & $-0.62 \%$ \\
& $(0.61)$ & $(-0.25)$ & & $(0.45)$ & $(-0.21)$ &
\end{tabular}

\section{PANEL 3. GERMANY}

\begin{tabular}{lcccccc}
\hline & Intercept & $\sigma_{\mathrm{t}}{ }^{2}$ & Adj. $\mathbf{R}^{2}$ & Intercept & $\sigma_{\mathrm{t}}$ & Adj. $\mathbf{R}^{\mathbf{2}}$ \\
\cline { 2 - 7 } $\mathbf{R}_{\mathrm{t}+1}-\mathbf{R}_{\mathrm{ft}+1}$ & 0.005 & -0.743 & $-0.30 \%$ & 0.010 & -0.145 & $-0.16 \%$ \\
& $(0.84)$ & $(-0.66)$ & & $(1.02)$ & $(-0.79)$ & \\
\hline PANEL 4. ITALY & & & & & \\
\hline & Intercept & $\sigma_{\mathrm{t}}{ }^{2}$ & Adj. $\mathbf{R}^{\mathbf{2}}$ & Intercept & $\sigma_{\mathrm{t}}$ & Adj. $\mathbf{R}^{\mathbf{2}}$ \\
\cline { 2 - 7 } $\mathbf{R}_{\mathrm{t}+1}-\mathbf{R}_{\mathrm{ft}+1}$ & -0.006 & 1.768 & $0.00 \%$ & -0.017 & 0.290 & $0.11 \%$ \\
& $(-0.71)$ & $(1.09)$ & & $(-1.04)$ & $(1.17)$ & \\
\hline
\end{tabular}

PANEL 5. JAPAN

\begin{tabular}{ccccccc}
\hline & Intercept & $\sigma_{\mathbf{t}}{ }^{2}$ & Adj. $\mathbf{R}^{\mathbf{2}}$ & Intercept & $\sigma_{\mathbf{t}}$ & Adj. $\mathbf{R}^{\mathbf{2}}$ \\
\cline { 2 - 7 } $\mathbf{R}_{\mathbf{t}+\mathbf{1}}-\mathbf{R}_{\mathrm{ft}+1}$ & -0.012 & 1.501 & $0.08 \%$ & -0.018 & 0.207 & $-0.02 \%$ \\
& $(-1.76)$ & $(1.01)$ & & $(-1.65)$ & $(1.04)$ & \\
\hline
\end{tabular}

PANEL 6. UNITED KINGDOM

\begin{tabular}{lcccccc}
\hline & Intercept & $\sigma_{\mathbf{t}}{ }^{\mathbf{2}}$ & Adj. $\mathbf{R}^{\mathbf{2}}$ & Intercept & $\sigma_{\mathbf{t}}$ & Adj. $\mathbf{R}^{\mathbf{2}}$ \\
\cline { 2 - 7 } $\mathbf{R}_{\mathbf{t}+1}-\mathbf{R}_{\mathrm{ft}+1}$ & 0.000 & 0.451 & $-0.58 \%$ & -0.001 & 0.057 & $-0.58 \%$ \\
& $(0.07)$ & $(0.33)$ & & $(-0.16)$ & $(0.37)$ & \\
\hline
\end{tabular}

PANEL 7. UNITED STATES

\begin{tabular}{lcccccc}
\hline & Intercept & $\sigma_{\mathbf{t}}{ }^{2}$ & Adj. $\mathbf{R}^{\mathbf{2}}$ & Intercept & $\sigma_{\mathbf{t}}$ & Adj. $\mathbf{R}^{\mathbf{2}}$ \\
\cline { 2 - 7 } $\mathbf{R}_{\mathbf{t}+\mathbf{1}}-\mathbf{R}_{\mathbf{f t}+1}$ & 0.007 & -0.906 & $0.15 \%$ & 0.008 & -0.079 & $-0.24 \%$ \\
& $(2.46)$ & $(-1.35)$ & & $(1.48)$ & $(-0.52)$ & \\
\hline
\end{tabular}


Table 4

qual-Weighted Risk Premia

The table contains the results of time-series regressions using monthly data over the period 1981-2002 for the United States and over 1990-2002 for the other countries. (For Italy, the time series of the implied risk premia starts in July 1990). $\mu_{\mathrm{t}}$ is the equal-weighted average annual implied risk premium. $\sigma_{\mathrm{t}}$ is the square root of 252 times the standard deviation of the daily returns on the market, computed over the previous month, where the 'market' is the CRSP value-weighted index for the United States and the MSCI index or other countries. $\varepsilon_{\mathrm{\mu t}}\left(\varepsilon_{\mathrm{\sigma t}}\right)$ is the residual from an AR (1) model for expected premia (standard deviation). Data for the United States are obtained from COMPUSTAT, CRSP and
$/ \mathrm{B} / \mathrm{E} / \mathrm{S}$. Data for other countries are obtained from Worldscope, Datastream and I/B/E/S. The numbers in parentheses are t-statistics computed using the Newey-West correction with 12 lags of autocorrelation in the first specification and 1 lag of autocorrelation in other specifications and also corrected for heteroskedasticity.

\begin{tabular}{|c|c|c|c|c|c|c|c|c|c|c|c|c|c|}
\hline \multicolumn{14}{|c|}{ PANEL 1. CANADA } \\
\hline & Intercept & $\sigma_{t}^{2}$ & $\Delta \sigma_{t}^{2}$ & $\mu_{\mathrm{t}-1}$ & $\varepsilon_{\sigma}^{2} t$ & Adj. $\mathbf{R}^{2}$ & & Intercept & $\sigma_{\mathrm{t}}$ & $\Delta \sigma_{\mathrm{t}}$ & $\mu_{\mathrm{t}-1}$ & $\varepsilon_{\sigma t}$ & Adj. $\mathbf{R}^{2}$ \\
\hline$\mu_{\mathrm{t}}$ & $\begin{array}{c}0.07 \\
(10.38)\end{array}$ & $\begin{array}{c}0.36 \\
(3.83)\end{array}$ & & & & $18.65 \%$ & $\mu_{\mathrm{t}}$ & $\begin{array}{c}0.06 \\
(6.09)\end{array}$ & $\begin{array}{c}0.16 \\
(3.98)\end{array}$ & & & & $24.80 \%$ \\
\hline$\mu_{\mathrm{t}}$ & $\begin{array}{c}0.01 \\
(3.00)\end{array}$ & $\begin{array}{c}0.04 \\
(2.35)\end{array}$ & & $\begin{array}{c}0.93 \\
(39.60)\end{array}$ & & $92.59 \%$ & $\mu_{\mathrm{t}}$ & $\begin{array}{c}0.00 \\
(2.55)\end{array}$ & $\begin{array}{c}0.02 \\
(2.10)\end{array}$ & & $\begin{array}{c}0.93 \\
(37.54)\end{array}$ & & $92.58 \%$ \\
\hline$\mu_{\mathrm{t}}$ & $\begin{array}{c}0.00 \\
(2.67)\end{array}$ & & $\begin{array}{c}0.05 \\
(2.00)\end{array}$ & $\begin{array}{c}0.95 \\
(47.45)\end{array}$ & & $92.63 \%$ & $\mu_{\mathrm{t}}$ & $\begin{array}{c}0.00 \\
(2.70)\end{array}$ & & $\begin{array}{c}0.02 \\
(1.95)\end{array}$ & $\begin{array}{c}0.95 \\
(47.66)\end{array}$ & & $92.61 \%$ \\
\hline$\Delta \mu_{\mathrm{t}}$ & $\begin{array}{c}0.00 \\
(0.95)\end{array}$ & & $\begin{array}{c}0.05 \\
(2.02)\end{array}$ & & & $2.58 \%$ & $\Delta \mu_{\mathrm{t}}$ & $\begin{array}{c}0.00 \\
(0.93)\end{array}$ & & $\begin{array}{c}0.02 \\
(1.96)\end{array}$ & & & $2.30 \%$ \\
\hline$\varepsilon_{\mu \mathrm{t}}$ & $\begin{array}{c}0.00 \\
(0.00) \\
\end{array}$ & & & & $\begin{array}{c}0.06 \\
(2.45) \\
\end{array}$ & $3.15 \%$ & $\varepsilon_{\mu \mathrm{t}}$ & $\begin{array}{c}0.00 \\
(0.00) \\
\end{array}$ & & & & $\begin{array}{c}0.03 \\
(2.31) \\
\end{array}$ & $2.84 \%$ \\
\hline \multicolumn{14}{|c|}{ PANEL 2. FRANCE } \\
\hline & Intercept & $\sigma_{t}{ }^{2}$ & $\Delta \sigma_{t}^{2}$ & $\mu_{\mathrm{t}-1}$ & $\varepsilon_{\sigma t}^{2}$ & Adj. $\mathbf{R}^{2}$ & & Intercept & $\sigma_{\mathrm{t}}$ & $\Delta \sigma_{\mathrm{t}}$ & $\mu_{\mathrm{t}-1}$ & $\varepsilon_{\sigma t}$ & Adj. $\mathbf{R}^{2}$ \\
\hline$\mu_{\mathrm{t}}$ & $\begin{array}{c}0.05 \\
(8.04)\end{array}$ & $\begin{array}{c}0.24 \\
(6.31)\end{array}$ & & & & $21.95 \%$ & $\mu_{\mathrm{t}}$ & $\begin{array}{c}0.03 \\
(4.75)\end{array}$ & $\begin{array}{c}0.14 \\
(8.39)\end{array}$ & & & & $25.96 \%$ \\
\hline$\mu_{\mathrm{t}}$ & $\begin{array}{c}0.00 \\
(2.33)\end{array}$ & $\begin{array}{c}0.04 \\
(4.26)\end{array}$ & & $\begin{array}{c}0.92 \\
(38.24)\end{array}$ & & $92.23 \%$ & $\mu_{\mathrm{t}}$ & $\begin{array}{c}0.00 \\
(0.65)\end{array}$ & $\begin{array}{c}0.02 \\
(3.38)\end{array}$ & & $\begin{array}{c}0.91 \\
(37.78)\end{array}$ & & $92.13 \%$ \\
\hline$\mu_{\mathrm{t}}$ & $\begin{array}{c}0.00 \\
(2.08)\end{array}$ & & $\begin{array}{c}0.05 \\
(3.24)\end{array}$ & $\begin{array}{c}0.96 \\
(42.01)\end{array}$ & & $92.33 \%$ & $\mu_{\mathrm{t}}$ & $\begin{array}{c}0.00 \\
(2.11)\end{array}$ & & $\begin{array}{c}0.02 \\
(2.68)\end{array}$ & $\begin{array}{c}0.96 \\
(41.01)\end{array}$ & & $92.12 \%$ \\
\hline$\Delta \mu_{\mathrm{t}}$ & $\begin{array}{c}0.00 \\
(0.94)\end{array}$ & & $\begin{array}{c}0.06 \\
(3.47)\end{array}$ & & & $8.46 \%$ & $\Delta \mu_{\mathrm{t}}$ & $\begin{array}{c}0.00 \\
(0.92)\end{array}$ & & $\begin{array}{c}0.03 \\
(2.88)\end{array}$ & & & $5.79 \%$ \\
\hline$\varepsilon_{\mu \mathrm{t}}$ & $\begin{array}{c}0.00 \\
(0.00) \\
\end{array}$ & & & & $\begin{array}{c}0.07 \\
(4.15) \\
\end{array}$ & $10.10 \%$ & $\varepsilon_{\mu \mathrm{t}}$ & $\begin{array}{c}0.00 \\
(0.00) \\
\end{array}$ & & & & $\begin{array}{c}0.03 \\
(3.10) \\
\end{array}$ & $7.23 \%$ \\
\hline \multicolumn{14}{|c|}{ PANEL 3. GERMANY } \\
\hline & Intercept & $\sigma_{t}^{2}$ & $\Delta \sigma_{t}^{2}$ & $\mu_{\mathrm{t}-1}$ & $\varepsilon_{\sigma t}^{2}$ & Adj. $R^{2}$ & & Intercept & $\sigma_{\mathrm{t}}$ & $\Delta \sigma_{\mathrm{t}}$ & $\mu_{\mathrm{t}-1}$ & $\varepsilon_{\sigma t}$ & Adj. $R^{2}$ \\
\hline$\mu_{\mathrm{t}}$ & $\begin{array}{c}0.03 \\
(2.88)\end{array}$ & $\begin{array}{c}0.38 \\
(6.66)\end{array}$ & & & & $24.01 \%$ & $\mu_{\mathrm{t}}$ & $\begin{array}{c}0.00 \\
(0.20)\end{array}$ & $\begin{array}{c}0.24 \\
(5.04)\end{array}$ & & & & $28.18 \%$ \\
\hline$\mu_{\mathrm{t}}$ & $\begin{array}{c}0.00 \\
(0.75)\end{array}$ & $\begin{array}{c}0.01 \\
(0.78)\end{array}$ & & $\begin{array}{c}0.99 \\
(47.10)\end{array}$ & & $96.92 \%$ & $\mu_{\mathrm{t}}$ & $\begin{array}{c}0.00 \\
(0.19)\end{array}$ & $\begin{array}{c}0.01 \\
(0.68)\end{array}$ & & $\begin{array}{c}0.99 \\
(47.26)\end{array}$ & & $96.92 \%$ \\
\hline$\mu_{\mathrm{t}}$ & $\begin{array}{c}0.00 \\
(1.01)\end{array}$ & & $\begin{array}{c}0.03 \\
(3.09)\end{array}$ & $\begin{array}{c}1.00 \\
(52.99)\end{array}$ & & $97.02 \%$ & $\mu_{\mathrm{t}}$ & $\begin{array}{c}0.00 \\
(1.02)\end{array}$ & & $\begin{array}{c}0.02 \\
(2.40)\end{array}$ & $\begin{array}{c}1.00 \\
(52.71)\end{array}$ & & $96.99 \%$ \\
\hline$\Delta \mu_{\mathrm{t}}$ & $\begin{array}{c}0.00 \\
(1.36)\end{array}$ & & $\begin{array}{c}0.03 \\
(3.12)\end{array}$ & & & $3.14 \%$ & $\Delta \mu_{\mathrm{t}}$ & $\begin{array}{c}0.00 \\
(1.35)\end{array}$ & & $\begin{array}{c}0.02 \\
(2.41)\end{array}$ & & & $1.96 \%$ \\
\hline$\varepsilon_{\mu \mathrm{t}}$ & $\begin{array}{c}0.00 \\
(0.00) \\
\end{array}$ & & & & $\begin{array}{c}0.03 \\
(2.36) \\
\end{array}$ & $2.16 \%$ & $\varepsilon_{\mu \mathrm{t}}$ & $\begin{array}{c}0.00 \\
(0.00) \\
\end{array}$ & & & & $\begin{array}{c}0.02 \\
(2.01) \\
\end{array}$ & $1.39 \%$ \\
\hline \multicolumn{14}{|c|}{ PANEL 4. ITALY } \\
\hline & Intercept & $\sigma_{t}^{2}$ & $\Delta \sigma_{t}^{2}$ & $\mu_{\mathrm{t}-1}$ & $\varepsilon_{\sigma t}^{2}$ & Adj. $R^{2}$ & & Intercept & $\sigma_{\mathrm{t}}$ & $\Delta \sigma_{t}$ & $\mu_{t-1}$ & $\varepsilon_{\sigma t}$ & Adj. $R^{2}$ \\
\hline$\mu_{\mathrm{t}}$ & $\begin{array}{c}0.03 \\
(2.42)\end{array}$ & $\begin{array}{c}0.23 \\
(2.20)\end{array}$ & & & & $4.03 \%$ & $\mu_{\mathrm{t}}$ & $\begin{array}{c}0.02 \\
(1.04)\end{array}$ & $\begin{array}{c}0.11 \\
(1.74)\end{array}$ & & & & $3.27 \%$ \\
\hline$\mu_{\mathrm{t}}$ & $\begin{array}{c}0.00 \\
(1.51)\end{array}$ & $\begin{array}{c}-0.01 \\
(-0.56)\end{array}$ & & $\begin{array}{c}0.97 \\
(39.09)\end{array}$ & & $93.13 \%$ & $\mu_{\mathrm{t}}$ & $\begin{array}{c}0.00 \\
(1.29)\end{array}$ & $\begin{array}{c}-0.01 \\
(-0.64)\end{array}$ & & $\begin{array}{c}0.97 \\
(39.46)\end{array}$ & & $93.13 \%$ \\
\hline$\mu_{\mathrm{t}}$ & $\begin{array}{c}0.00 \\
(1.41)\end{array}$ & & $\begin{array}{c}0.00 \\
(-0.15)\end{array}$ & $\begin{array}{c}0.97 \\
(38.99)\end{array}$ & & $93.11 \%$ & $\mu_{\mathrm{t}}$ & $\begin{array}{c}0.00 \\
(1.41)\end{array}$ & & $\begin{array}{c}0.00 \\
(-0.11)\end{array}$ & $\begin{array}{c}0.97 \\
(39.03)\end{array}$ & & $93.11 \%$ \\
\hline$\Delta \mu_{\mathrm{t}}$ & $\begin{array}{c}0.00 \\
(1.07)\end{array}$ & & $\begin{array}{c}0.00 \\
(-0.17)\end{array}$ & & & $-0.66 \%$ & $\Delta \mu_{\mathrm{t}}$ & $\begin{array}{c}0.00 \\
(1.07)\end{array}$ & & $\begin{array}{c}0.00 \\
(-0.13)\end{array}$ & & & $-0.67 \%$ \\
\hline$\varepsilon_{\mu \mathrm{t}}$ & $\begin{array}{c}0.00 \\
(0.01) \\
\end{array}$ & & & & $\begin{array}{c}-0.01 \\
(-0.37) \\
\end{array}$ & $-0.55 \%$ & $\varepsilon_{\mu \mathrm{t}}$ & $\begin{array}{c}0.00 \\
(0.01) \\
\end{array}$ & & & & $\begin{array}{c}-0.01 \\
(-0.37)\end{array}$ & $-0.57 \%$ \\
\hline
\end{tabular}




\begin{tabular}{|c|c|c|c|c|c|c|c|c|c|c|c|c|c|}
\hline \multicolumn{14}{|c|}{ PANEL 5. JAPAN } \\
\hline & Intercept & $\sigma_{t}^{2}$ & $\Delta \sigma_{t}^{2}$ & $\mu_{t-1}$ & $\varepsilon_{\sigma}^{2} t$ & Adj. $R^{2}$ & & Intercept & $\sigma_{\mathrm{t}}$ & $\Delta \sigma_{\mathrm{t}}$ & $\mu_{t-1}$ & $\varepsilon_{\sigma t}$ & Adj. $\mathbf{R}^{2}$ \\
\hline$\mu_{\mathrm{t}}$ & $\begin{array}{c}0.05 \\
(3.88)\end{array}$ & $\begin{array}{c}-0.02 \\
(-0.13)\end{array}$ & & & & $-0.63 \%$ & $\mu_{\mathrm{t}}$ & $\begin{array}{c}0.04 \\
(3.10)\end{array}$ & $\begin{array}{c}0.05 \\
(0.63)\end{array}$ & & & & $-0.16 \%$ \\
\hline$\mu_{\mathrm{t}}$ & $\begin{array}{c}0.00 \\
(1.38)\end{array}$ & $\begin{array}{c}0.01 \\
(0.49)\end{array}$ & & $\begin{array}{c}0.99 \\
(89.33)\end{array}$ & & $98.17 \%$ & $\mu_{\mathrm{t}}$ & $\begin{array}{c}0.00 \\
(0.57)\end{array}$ & $\begin{array}{c}0.00 \\
(0.59)\end{array}$ & & $\begin{array}{c}0.99 \\
(88.39)\end{array}$ & & $98.17 \%$ \\
\hline$\mu_{\mathrm{t}}$ & $\begin{array}{c}0.00 \\
(2.09)\end{array}$ & & $\begin{array}{c}0.02 \\
(1.86)\end{array}$ & $\begin{array}{c}0.99 \\
(89.10)\end{array}$ & & $98.19 \%$ & $\mu_{\mathrm{t}}$ & $\begin{array}{c}0.00 \\
(2.07)\end{array}$ & & $\begin{array}{c}0.01 \\
(1.76)\end{array}$ & $\begin{array}{c}0.99 \\
(89.18)\end{array}$ & & $98.19 \%$ \\
\hline$\Delta \mu_{\mathrm{t}}$ & $\begin{array}{c}0.00 \\
(1.78)\end{array}$ & & $\begin{array}{c}0.02 \\
(1.88)\end{array}$ & & & $0.38 \%$ & $\Delta \mu_{\mathrm{t}}$ & $\begin{array}{c}0.00 \\
(1.77)\end{array}$ & & $\begin{array}{c}0.01 \\
(1.78)\end{array}$ & & & $0.56 \%$ \\
\hline$\varepsilon_{\mu \mathrm{t}}$ & $\begin{array}{c}0.00 \\
(0.00) \\
\end{array}$ & & & & $\begin{array}{c}0.01 \\
(0.97) \\
\end{array}$ & $-0.30 \%$ & $\varepsilon_{\mu \mathrm{t}}$ & $\begin{array}{c}0.00 \\
(0.00) \\
\end{array}$ & & & & $\begin{array}{c}0.01 \\
(1.16) \\
\end{array}$ & $-0.06 \%$ \\
\hline \multicolumn{14}{|c|}{ PANEL 6. UNITED KINGDOM } \\
\hline & Intercept & $\sigma_{t}^{2}$ & $\Delta \sigma_{t}{ }^{2}$ & $\mu_{\mathrm{t}-1}$ & $\varepsilon_{\sigma}^{2} t$ & Adj. $R^{2}$ & & Intercept & $\sigma_{\mathrm{t}}$ & $\Delta \sigma_{\mathrm{t}}$ & $\mu_{\mathrm{t}-1}$ & $\varepsilon_{\sigma t}$ & Adj. $R^{2}$ \\
\hline$\mu_{\mathrm{t}}$ & $\begin{array}{c}0.06 \\
(10.15)\end{array}$ & $\begin{array}{c}0.47 \\
(7.23)\end{array}$ & & & & $33.87 \%$ & $\mu_{\mathrm{t}}$ & $\begin{array}{c}0.04 \\
(7.13)\end{array}$ & $\begin{array}{c}0.23 \\
(14.06)\end{array}$ & & & & $40.14 \%$ \\
\hline$\mu_{\mathrm{t}}$ & $\begin{array}{c}0.00 \\
(2.50)\end{array}$ & $\begin{array}{c}0.08 \\
(3.05)\end{array}$ & & $\begin{array}{c}0.92 \\
(34.99)\end{array}$ & & $93.66 \%$ & $\mu_{\mathrm{t}}$ & $\begin{array}{c}0.00 \\
(0.89)\end{array}$ & $\begin{array}{c}0.04 \\
(3.38)\end{array}$ & & $\begin{array}{c}0.91 \\
(31.77)\end{array}$ & & $93.70 \%$ \\
\hline$\mu_{\mathrm{t}}$ & $\begin{array}{c}0.00 \\
(1.49)\end{array}$ & & $\begin{array}{c}0.11 \\
(4.82)\end{array}$ & $\begin{array}{c}0.97 \\
(51.04)\end{array}$ & & $94.28 \%$ & $\mu_{\mathrm{t}}$ & $\begin{array}{c}0.00 \\
(1.48)\end{array}$ & & $\begin{array}{c}0.05 \\
(5.17)\end{array}$ & $\begin{array}{c}0.97 \\
(50.50)\end{array}$ & & $94.31 \%$ \\
\hline$\Delta \mu_{\mathrm{t}}$ & $\begin{array}{c}0.00 \\
(1.06)\end{array}$ & & $\begin{array}{c}0.11 \\
(5.11)\end{array}$ & & & $18.35 \%$ & $\Delta \mu_{\mathrm{t}}$ & $\begin{array}{c}0.00 \\
(1.03)\end{array}$ & & $\begin{array}{c}0.05 \\
(5.43)\end{array}$ & & & $18.81 \%$ \\
\hline$\varepsilon_{\mu \mathrm{t}}$ & $\begin{array}{c}0.00 \\
(0.00) \\
\end{array}$ & & & & $\begin{array}{c}0.12 \\
(4.52) \\
\end{array}$ & $17.58 \%$ & $\varepsilon_{\mu \mathrm{t}}$ & $\begin{array}{c}0.00 \\
(0.00) \\
\end{array}$ & & & & $\begin{array}{c}0.06 \\
(5.12) \\
\end{array}$ & $18.55 \%$ \\
\hline \multicolumn{14}{|c|}{ PANEL 7. UNITED STATES } \\
\hline & Intercept & $\sigma_{t}^{2}$ & $\Delta \sigma_{t}^{2}$ & $\mu_{\mathrm{t}-1}$ & $\varepsilon_{\sigma}^{2} t$ & Adj. $\mathrm{R}^{2}$ & & Intercept & $\sigma_{\mathrm{t}}$ & $\Delta \sigma_{t}$ & $\mu_{\mathrm{t}-1}$ & $\varepsilon_{\sigma t}$ & Adj. $\mathbf{R}^{2}$ \\
\hline$\mu_{t}$ & $\begin{array}{c}0.04 \\
(15.94)\end{array}$ & $\begin{array}{c}0.09 \\
(1.78)\end{array}$ & & & & $8.83 \%$ & $\mu_{t}$ & $\begin{array}{c}0.04 \\
(9.01)\end{array}$ & $\begin{array}{c}0.07 \\
(3.18)\end{array}$ & & & & $16.33 \%$ \\
\hline$\mu_{t}$ & $\begin{array}{c}0.00 \\
(3.18)\end{array}$ & $\begin{array}{c}0.05 \\
(11.15)\end{array}$ & & $\begin{array}{c}0.89 \\
(34.78)\end{array}$ & & $85.91 \%$ & $\mu_{t}$ & $\begin{array}{c}0.00 \\
(1.77)\end{array}$ & $\begin{array}{c}0.03 \\
(3.43)\end{array}$ & & $\begin{array}{c}0.87 \\
(28.14)\end{array}$ & & $85.23 \%$ \\
\hline$\mu_{\mathrm{t}}$ & $\begin{array}{c}0.00 \\
(2.77)\end{array}$ & & $\begin{array}{c}0.03 \\
(2.22)\end{array}$ & $\begin{array}{c}0.93 \\
(35.91)\end{array}$ & & $84.52 \%$ & $\mu_{t}$ & $\begin{array}{c}0.00 \\
(2.83)\end{array}$ & & $\begin{array}{c}0.02 \\
(2.68)\end{array}$ & $\begin{array}{c}0.93 \\
(36.42)\end{array}$ & & $84.54 \%$ \\
\hline$\Delta \mu_{t}$ & $\begin{array}{c}0.00 \\
(0.20)\end{array}$ & & $\begin{array}{c}0.03 \\
(2.38)\end{array}$ & & & $8.11 \%$ & $\Delta \mu_{\mathrm{t}}$ & $\begin{array}{c}0.00 \\
(0.20)\end{array}$ & & $\begin{array}{c}0.02 \\
(2.83)\end{array}$ & & & $8.16 \%$ \\
\hline$\varepsilon_{\mu \mathrm{t}}$ & $\begin{array}{c}0.00 \\
(0.00) \\
\end{array}$ & & & & $\begin{array}{c}0.05 \\
(10.53) \\
\end{array}$ & $14.99 \%$ & $\varepsilon_{\mu \mathrm{t}}$ & $\begin{array}{c}0.00 \\
(0.00) \\
\end{array}$ & & & & $\begin{array}{c}0.03 \\
(4.01) \\
\end{array}$ & $11.79 \%$ \\
\hline
\end{tabular}


Table 5

Volatility and Value-Weighted Risk Premia

The table contains the results of time-series regressions using monthly data over the period 1981-2002 for the United States and over 1990-2002 for the other countries. (For Italy, the time series of the implied risk premia starts in July 1990). $\mu_{\mathrm{t}}$ is the value-weighted average annual implied risk premium. $\sigma_{\mathrm{t}}$ is the square root of 252 times the standard the time series of the implied risk premarket, computed over the previous month, where the 'market' is the CRSP value-weighted index for the United States and the MSCI index
deviation of the daily returns on the market for other countries. $\varepsilon_{\mathrm{pt}}\left(\varepsilon_{\mathrm{\sigma} t}\right)$ is the residual from an AR (1) model for expected premia (standard deviation). Data for the United States are obtained from COMPUSTAT, CRSP for other countries. $\varepsilon_{\mu t}\left(\varepsilon_{\sigma t}\right)$ is the residual from an AR $(1)$ model for expected premia (standard deviation). Data for the United States are obtained from COMPUSTAT, CRSP
and I/B/E/S. Data for other countries are obtained from Worldscope, Datastream and I/B/E/S. The numbers in parentheses are $t$-statistics computed using the Newey-West

\begin{tabular}{|c|c|c|c|c|c|c|c|c|c|c|c|c|c|}
\hline \multicolumn{14}{|c|}{ PANEL 1. CANADA } \\
\hline & Intercept & $\sigma_{t}^{2}$ & $\Delta \sigma_{t}^{2}$ & $\mu_{\mathrm{t}-1}$ & $\varepsilon_{\sigma}^{2} t$ & Adj. $\mathrm{R}^{2}$ & & Intercept & $\sigma_{\mathrm{t}}$ & $\Delta \sigma_{t}$ & $\mu_{\mathrm{t}-1}$ & $\varepsilon_{\sigma t}$ & Adj. $R^{2}$ \\
\hline$\mu_{\mathrm{t}}$ & $\begin{array}{c}0.05 \\
(8.64)\end{array}$ & $\begin{array}{c}0.08 \\
(1.01)\end{array}$ & & & & $1.69 \%$ & $\mu_{\mathrm{t}}$ & $\begin{array}{c}0.04 \\
(5.28)\end{array}$ & $\begin{array}{c}0.04 \\
(1.06)\end{array}$ & & & & $2.68 \%$ \\
\hline$\mu_{\mathrm{t}}$ & $\begin{array}{c}0.01 \\
(3.20)\end{array}$ & $\begin{array}{c}0.01 \\
(0.40)\end{array}$ & & $\begin{array}{c}0.87 \\
(21.85)\end{array}$ & & $80.28 \%$ & $\mu_{\mathrm{t}}$ & $\begin{array}{c}0.01 \\
(3.05)\end{array}$ & $\begin{array}{c}0.00 \\
(0.30)\end{array}$ & & $\begin{array}{c}0.87 \\
(21.59)\end{array}$ & & $80.28 \%$ \\
\hline$\mu_{\mathrm{t}}$ & $\begin{array}{c}0.01 \\
(3.23)\end{array}$ & & $\begin{array}{c}0.03 \\
(1.19)\end{array}$ & $\begin{array}{c}0.88 \\
(22.29)\end{array}$ & & $80.42 \%$ & $\mu_{\mathrm{t}}$ & $\begin{array}{c}0.01 \\
(3.24)\end{array}$ & & $\begin{array}{c}0.01 \\
(1.30)\end{array}$ & $\begin{array}{c}0.87 \\
(22.31)\end{array}$ & & $80.44 \%$ \\
\hline$\Delta \mu_{\mathrm{t}}$ & $\begin{array}{c}0.00 \\
(0.74)\end{array}$ & & $\begin{array}{c}0.03 \\
(1.09)\end{array}$ & & & $0.06 \%$ & $\Delta \mu_{\mathrm{t}}$ & $\begin{array}{c}0.00 \\
(0.74)\end{array}$ & & $\begin{array}{c}0.01 \\
(1.15)\end{array}$ & & & $0.10 \%$ \\
\hline$\varepsilon_{\mu \mathrm{t}}$ & $\begin{array}{c}0.00 \\
(0.00) \\
\end{array}$ & & & & $\begin{array}{c}0.02 \\
(1.03) \\
\end{array}$ & $-0.05 \%$ & $\varepsilon_{\mu \mathrm{t}}$ & $\begin{array}{c}0.00 \\
(0.00) \\
\end{array}$ & & & & $\begin{array}{c}0.01 \\
(1.14) \\
\end{array}$ & $0.06 \%$ \\
\hline \multicolumn{14}{|c|}{ PANEL 2. FRANCE } \\
\hline & Intercept & $\sigma_{t}^{2}$ & $\Delta \sigma_{t}^{2}$ & $\mu_{\mathrm{t}-1}$ & $\varepsilon_{\sigma t}^{2}$ & Adj. $R^{2}$ & & Intercept & $\sigma_{\mathrm{t}}$ & $\Delta \sigma_{\mathrm{t}}$ & $\mu_{\mathrm{t}-1}$ & $\varepsilon_{\sigma t}$ & Adj. $R^{2}$ \\
\hline$\mu_{\mathrm{t}}$ & $\begin{array}{c}0.02 \\
(11.62)\end{array}$ & $\begin{array}{c}0.12 \\
(9.17)\end{array}$ & & & & $30.38 \%$ & $\mu_{\mathrm{t}}$ & $\begin{array}{c}0.02 \\
(5.52)\end{array}$ & $\begin{array}{c}0.07 \\
(5.33)\end{array}$ & & & & $29.93 \%$ \\
\hline$\mu_{\mathrm{t}}$ & $\begin{array}{c}0.00 \\
(3.49)\end{array}$ & $\begin{array}{c}0.03 \\
(3.97)\end{array}$ & & $\begin{array}{c}0.81 \\
(20.18)\end{array}$ & & $78.16 \%$ & $\mu_{\mathrm{t}}$ & $\begin{array}{c}0.00 \\
(1.77)\end{array}$ & $\begin{array}{c}0.02 \\
(3.35)\end{array}$ & & $\begin{array}{c}0.82 \\
(20.31)\end{array}$ & & $77.85 \%$ \\
\hline$\mu_{\mathrm{t}}$ & $\begin{array}{c}0.00 \\
(2.64)\end{array}$ & & $\begin{array}{c}0.03 \\
(2.38)\end{array}$ & $\begin{array}{c}0.90 \\
(24.32)\end{array}$ & & $77.37 \%$ & $\mu_{\mathrm{t}}$ & $\begin{array}{c}0.00 \\
(2.71)\end{array}$ & & $\begin{array}{c}0.01 \\
(1.96)\end{array}$ & $\begin{array}{c}0.90 \\
(24.16)\end{array}$ & & $77.04 \%$ \\
\hline$\Delta \mu_{\mathrm{t}}$ & $\begin{array}{c}0.00 \\
(0.45)\end{array}$ & & $\begin{array}{c}0.03 \\
(2.90)\end{array}$ & & & $4.41 \%$ & $\Delta \mu_{\mathrm{t}}$ & $\begin{array}{c}0.00 \\
(0.44)\end{array}$ & & $\begin{array}{c}0.01 \\
(2.23)\end{array}$ & & & $2.80 \%$ \\
\hline$\varepsilon_{\mu \mathrm{t}}$ & $\begin{array}{c}0.00 \\
(0.00) \\
\end{array}$ & & & & $\begin{array}{c}0.04 \\
(3.34) \\
\end{array}$ & $6.46 \%$ & $\varepsilon_{\mu \mathrm{t}}$ & $\begin{array}{c}0.00 \\
(0.00) \\
\end{array}$ & & & & $\begin{array}{c}0.02 \\
(2.51) \\
\end{array}$ & $4.66 \%$ \\
\hline \multicolumn{14}{|c|}{ PANEL 3. GERMANY } \\
\hline & Intercept & $\sigma_{t}^{2}$ & $\Delta \sigma_{t}^{2}$ & $\mu_{\mathrm{t}-1}$ & $\varepsilon_{\sigma}^{2} t$ & Adj. $R^{2}$ & & Intercept & $\sigma_{\mathrm{t}}$ & $\Delta \sigma_{t}$ & $\mu_{\mathrm{t}-1}$ & $\varepsilon_{\sigma t}$ & Adj. $R^{2}$ \\
\hline$\mu_{\mathrm{t}}$ & $\begin{array}{c}0.01 \\
(1.99)\end{array}$ & $\begin{array}{c}0.16 \\
(5.26)\end{array}$ & & & & $26.41 \%$ & $\mu_{\mathrm{t}}$ & $\begin{array}{c}0.00 \\
(-0.48)\end{array}$ & $\begin{array}{c}0.09 \\
(3.59)\end{array}$ & & & & $26.24 \%$ \\
\hline$\mu_{\mathrm{t}}$ & $\begin{array}{c}0.00 \\
(1.34)\end{array}$ & $\begin{array}{c}0.03 \\
(1.70)\end{array}$ & & $\begin{array}{c}0.87 \\
(17.26)\end{array}$ & & $83.08 \%$ & $\mu_{\mathrm{t}}$ & $\begin{array}{c}0.00 \\
(-0.40)\end{array}$ & $\begin{array}{c}0.02 \\
(1.74)\end{array}$ & & $\begin{array}{c}0.87 \\
(17.52)\end{array}$ & & $83.06 \%$ \\
\hline$\mu_{\mathrm{t}}$ & $\begin{array}{c}0.00 \\
(1.87)\end{array}$ & & $\begin{array}{c}0.01 \\
(0.66)\end{array}$ & $\begin{array}{c}0.92 \\
(19.52)\end{array}$ & & $82.61 \%$ & $\mu_{t}$ & $\begin{array}{c}0.00 \\
(1.88)\end{array}$ & & $\begin{array}{c}0.01 \\
(0.69)\end{array}$ & $\begin{array}{c}0.92 \\
(19.57)\end{array}$ & & $82.60 \%$ \\
\hline$\Delta \mu_{\mathrm{t}}$ & $\begin{array}{c}0.00 \\
(0.97)\end{array}$ & & $\begin{array}{c}0.01 \\
(0.66)\end{array}$ & & & $-0.18 \%$ & $\Delta \mu_{\mathrm{t}}$ & $\begin{array}{c}0.00 \\
(0.97)\end{array}$ & & $\begin{array}{c}0.01 \\
(0.65)\end{array}$ & & & $-0.22 \%$ \\
\hline$\varepsilon_{\mu \mathrm{t}}$ & $\begin{array}{c}0.00 \\
(0.00) \\
\end{array}$ & & & & $\begin{array}{c}0.02 \\
(1.08) \\
\end{array}$ & $0.81 \%$ & $\varepsilon_{\mu \mathrm{t}}$ & $\begin{array}{c}0.00 \\
(0.00) \\
\end{array}$ & & & & $\begin{array}{c}0.01 \\
(1.06) \\
\end{array}$ & $0.67 \%$ \\
\hline \multicolumn{14}{|c|}{ PANEL 4. ITALY } \\
\hline & Intercept & $\sigma_{t}^{2}$ & $\Delta \sigma_{t}^{2}$ & $\mu_{\mathrm{t}-1}$ & $\varepsilon_{\sigma}^{2} t$ & Adj. $R^{2}$ & & Intercept & $\sigma_{t}$ & $\Delta \sigma_{t}$ & $\mu_{\mathrm{t}-1}$ & $\varepsilon_{\sigma t}$ & Adj. $\mathbf{R}^{2}$ \\
\hline$\mu_{\mathrm{t}}$ & $\begin{array}{c}0.00 \\
(-0.35)\end{array}$ & $\begin{array}{c}0.20 \\
(2.40)\end{array}$ & & & & $4.25 \%$ & $\mu_{\mathrm{t}}$ & $\begin{array}{c}-0.01 \\
(-0.87)\end{array}$ & $\begin{array}{c}0.09 \\
(1.75)\end{array}$ & & & & $3.24 \%$ \\
\hline$\mu_{\mathrm{t}}$ & $\begin{array}{c}0.00 \\
(1.47)\end{array}$ & $\begin{array}{c}-0.01 \\
(-0.57)\end{array}$ & & $\begin{array}{c}0.96 \\
(38.82)\end{array}$ & & $93.28 \%$ & $\mu_{\mathrm{t}}$ & $\begin{array}{c}0.00 \\
(1.26)\end{array}$ & $\begin{array}{c}-0.01 \\
(-0.75)\end{array}$ & & $\begin{array}{c}0.96 \\
(39.30)\end{array}$ & & $93.29 \%$ \\
\hline$\mu_{\mathrm{t}}$ & $\begin{array}{c}0.00 \\
(1.39)\end{array}$ & & $\begin{array}{c}0.00 \\
(0.19)\end{array}$ & $\begin{array}{c}0.96 \\
(39.49)\end{array}$ & & $93.26 \%$ & $\mu_{\mathrm{t}}$ & $\begin{array}{c}0.00 \\
(1.39)\end{array}$ & & $\begin{array}{c}0.00 \\
(0.23)\end{array}$ & $\begin{array}{c}0.96 \\
(39.50)\end{array}$ & & $93.26 \%$ \\
\hline$\Delta \mu_{\mathrm{t}}$ & $\begin{array}{c}0.00 \\
(1.17)\end{array}$ & & $\begin{array}{c}0.00 \\
(0.17)\end{array}$ & & & $-0.66 \%$ & $\Delta \mu_{\mathrm{t}}$ & $\begin{array}{c}0.00 \\
(1.17)\end{array}$ & & $\begin{array}{c}0.00 \\
(0.20)\end{array}$ & & & $-0.65 \%$ \\
\hline$\varepsilon_{\mu t}$ & $\begin{array}{c}0.00 \\
(0.01) \\
\end{array}$ & & & & $\begin{array}{c}-0.01 \\
(-0.21)\end{array}$ & $-0.64 \%$ & $\varepsilon_{\mu \mathrm{t}}$ & $\begin{array}{c}0.00 \\
(0.01) \\
\end{array}$ & & & & $\begin{array}{c}0.00 \\
(-0.25) \\
\end{array}$ & $-0.63 \%$ \\
\hline
\end{tabular}




\begin{tabular}{|c|c|c|c|c|c|c|c|c|c|c|c|c|c|}
\hline \multicolumn{14}{|c|}{ PANEL 5. JAPAN } \\
\hline & Intercept & $\sigma_{t}^{2}$ & $\Delta \sigma_{t}^{2}$ & $\mu_{t-1}$ & $\varepsilon_{\sigma}^{2} t$ & Adj. $\mathbf{R}^{2}$ & & Intercept & $\sigma_{\mathrm{t}}$ & $\Delta \sigma_{t}$ & $\mu_{\mathrm{t}-1}$ & $\varepsilon_{\sigma t}$ & Adj. $R^{2}$ \\
\hline$\mu_{\mathrm{t}}$ & $\begin{array}{c}0.03 \\
(4.22)\end{array}$ & $\begin{array}{c}-0.04 \\
(-0.47)\end{array}$ & & & & $-0.36 \%$ & $\mu_{t}$ & $\begin{array}{c}0.03 \\
(3.26)\end{array}$ & $\begin{array}{c}0.01 \\
(0.17)\end{array}$ & & & & $-0.61 \%$ \\
\hline$\mu_{\mathrm{t}}$ & $\begin{array}{c}0.00 \\
(1.80)\end{array}$ & $\begin{array}{c}0.00 \\
(0.02)\end{array}$ & & $\begin{array}{c}0.98 \\
(61.40)\end{array}$ & & $95.71 \%$ & $\mu_{t}$ & $\begin{array}{c}0.00 \\
(1.27)\end{array}$ & $\begin{array}{c}0.00 \\
(-0.08)\end{array}$ & & $\begin{array}{c}0.98 \\
(61.49)\end{array}$ & & $95.71 \%$ \\
\hline$\mu_{\mathrm{t}}$ & $\begin{array}{c}0.00 \\
(2.33)\end{array}$ & & $\begin{array}{c}0.02 \\
(1.77)\end{array}$ & $\begin{array}{c}0.98 \\
(61.58)\end{array}$ & & $95.76 \%$ & $\mu_{\mathrm{t}}$ & $\begin{array}{c}0.00 \\
(2.34)\end{array}$ & & $\begin{array}{c}0.01 \\
(1.60)\end{array}$ & $\begin{array}{c}0.98 \\
(61.79)\end{array}$ & & $95.77 \%$ \\
\hline$\Delta \mu_{\mathrm{t}}$ & $\begin{array}{c}0.00 \\
(1.49)\end{array}$ & & $\begin{array}{c}0.02 \\
(1.81)\end{array}$ & & & $0.63 \%$ & $\Delta \mu_{\mathrm{t}}$ & $\begin{array}{c}0.00 \\
(1.48)\end{array}$ & & $\begin{array}{c}0.01 \\
(1.62)\end{array}$ & & & $0.88 \%$ \\
\hline$\varepsilon_{\mu \mathrm{t}}$ & $\begin{array}{c}0.00 \\
(0.00) \\
\end{array}$ & & & & $\begin{array}{c}0.01 \\
(0.64) \\
\end{array}$ & $-0.48 \%$ & $\varepsilon_{\mu \mathrm{t}}$ & $\begin{array}{c}0.00 \\
(0.00) \\
\end{array}$ & & & & $\begin{array}{c}0.00 \\
(0.73) \\
\end{array}$ & $-0.37 \%$ \\
\hline \multicolumn{14}{|c|}{ PANEL 6. UNITED KINGDOM } \\
\hline & Intercept & $\sigma_{t}^{2}$ & $\Delta \sigma_{t}^{2}$ & $\mu_{\mathrm{t}-1}$ & $\varepsilon_{\sigma^{2} t}$ & Adj. $R^{2}$ & & Intercept & $\sigma_{\mathrm{t}}$ & $\Delta \sigma_{t}$ & $\mu_{\mathrm{t}-1}$ & $\varepsilon_{\sigma \mathrm{t}}$ & Adj. $R^{2}$ \\
\hline$\mu_{\mathrm{t}}$ & $\begin{array}{c}0.02 \\
(10.00)\end{array}$ & $\begin{array}{c}0.20 \\
(8.21)\end{array}$ & & & & $27.43 \%$ & $\mu_{\mathrm{t}}$ & $\begin{array}{c}0.02 \\
(4.84)\end{array}$ & $\begin{array}{c}0.09 \\
(5.97)\end{array}$ & & & & $27.69 \%$ \\
\hline$\mu_{\mathrm{t}}$ & $\begin{array}{c}0.01 \\
(2.90)\end{array}$ & $\begin{array}{c}0.08 \\
(3.17)\end{array}$ & & $\begin{array}{c}0.68 \\
(6.67)\end{array}$ & & $63.28 \%$ & $\mu_{\mathrm{t}}$ & $\begin{array}{c}0.00 \\
(2.15)\end{array}$ & $\begin{array}{c}0.04 \\
(3.18)\end{array}$ & & $\begin{array}{c}0.68 \\
(6.62)\end{array}$ & & $63.53 \%$ \\
\hline$\mu_{\mathrm{t}}$ & $\begin{array}{c}0.01 \\
(2.57)\end{array}$ & & $\begin{array}{c}0.06 \\
(1.90)\end{array}$ & $\begin{array}{c}0.79 \\
(9.63)\end{array}$ & & $61.58 \%$ & $\mu_{t}$ & $\begin{array}{c}0.01 \\
(2.58)\end{array}$ & & $\begin{array}{c}0.04 \\
(2.62)\end{array}$ & $\begin{array}{c}0.80 \\
(9.97)\end{array}$ & & $62.78 \%$ \\
\hline$\Delta \mu_{\mathrm{t}}$ & $\begin{array}{c}0.00 \\
(0.54)\end{array}$ & & $\begin{array}{c}0.07 \\
(2.13)\end{array}$ & & & $5.04 \%$ & $\Delta \mu_{\mathrm{t}}$ & $\begin{array}{c}0.00 \\
(0.52)\end{array}$ & & $\begin{array}{c}0.04 \\
(2.71)\end{array}$ & & & $8.15 \%$ \\
\hline$\varepsilon_{\mu \mathrm{t}}$ & $\begin{array}{c}0.00 \\
(0.00) \\
\end{array}$ & & & & $\begin{array}{c}0.09 \\
(2.95) \\
\end{array}$ & $7.54 \%$ & $\varepsilon_{\mu \mathrm{t}}$ & $\begin{array}{c}0.00 \\
(0.00) \\
\end{array}$ & & & & $\begin{array}{c}0.05 \\
(3.47) \\
\end{array}$ & $10.39 \%$ \\
\hline \multicolumn{14}{|c|}{ PANEL 7. UNITED STATES } \\
\hline & Intercept & $\sigma_{t}^{2}$ & $\Delta \sigma_{t}^{2}$ & $\mu_{\mathrm{t}-1}$ & $\varepsilon_{\sigma}^{2} t$ & Adj. $R^{2}$ & & Intercept & $\sigma_{\mathrm{t}}$ & $\Delta \sigma_{\mathrm{t}}$ & $\mu_{t-1}$ & $\varepsilon_{\sigma \mathrm{t}}$ & Adj. $\mathbf{R}^{2}$ \\
\hline$\mu_{\mathrm{t}}$ & $\begin{array}{c}0.03 \\
(14.61)\end{array}$ & $\begin{array}{c}0.04 \\
(1.17)\end{array}$ & & & & $2.41 \%$ & $\mu_{\mathrm{t}}$ & $\begin{array}{c}0.02 \\
(7.11)\end{array}$ & $\begin{array}{c}0.03 \\
(1.42)\end{array}$ & & & & $4.24 \%$ \\
\hline$\mu_{t}$ & $\begin{array}{c}0.00 \\
(2.90)\end{array}$ & $\begin{array}{c}0.03 \\
(6.75)\end{array}$ & & $\begin{array}{c}0.84 \\
(20.52)\end{array}$ & & $72.39 \%$ & $\mu_{t}$ & $\begin{array}{c}0.00 \\
(1.76)\end{array}$ & $\begin{array}{c}0.02 \\
(2.67)\end{array}$ & & $\begin{array}{c}0.83 \\
(19.43)\end{array}$ & & $71.61 \%$ \\
\hline$\mu_{t}$ & $\begin{array}{c}0.00 \\
(3.20)\end{array}$ & & $\begin{array}{c}0.02 \\
(1.70)\end{array}$ & $\begin{array}{c}0.86 \\
(19.55)\end{array}$ & & $70.75 \%$ & $\mu_{t}$ & $\begin{array}{c}0.00 \\
(3.27)\end{array}$ & & $\begin{array}{c}0.01 \\
(1.66)\end{array}$ & $\begin{array}{c}0.85 \\
(19.65)\end{array}$ & & $70.60 \%$ \\
\hline$\Delta \mu_{\mathrm{t}}$ & $\begin{array}{c}0.00 \\
(0.45)\end{array}$ & & $\begin{array}{c}0.02 \\
(1.83)\end{array}$ & & & $3.49 \%$ & $\Delta \mu_{\mathrm{t}}$ & $\begin{array}{c}0.00 \\
(0.45)\end{array}$ & & $\begin{array}{c}0.01 \\
(1.77)\end{array}$ & & & $2.81 \%$ \\
\hline$\varepsilon_{\mu t}$ & $\begin{array}{c}0.00 \\
(0.00) \\
\end{array}$ & & & & $\begin{array}{c}0.03 \\
(6.99) \\
\end{array}$ & $7.35 \%$ & $\varepsilon_{\mu t}$ & $\begin{array}{c}0.00 \\
(0.00) \\
\end{array}$ & & & & $\begin{array}{c}0.02 \\
(2.71) \\
\end{array}$ & $4.71 \%$ \\
\hline
\end{tabular}


Table 6

Correlations Matrix

The table contains the Spearman correlation coefficients and the corresponding p-values for the test that correlations are zero across implied risk premia and the measures of volatility of returns for each of the G-7 countries. The statistics are computed over the period 1981-2002 for the United States and over 1990-2002 for the other countries. (For Italy, the time series of implied risk premia starts in July 1990). $\mu_{t}$ is the average (equal-or value-weighted) annual implied risk premium. $\sigma_{\mathrm{t}}$ is the square root of 252 times the standard deviation of the daily returns on the market, computed over the previous month, where the 'market' is the CRSP value-weighted index for the United States and the MSCI index for other countries. Data for the United States are obtained from COMPUSTAT, CRSP, and I/B/E/S. Data for other countries are obtained from Worldscope, Datastream and I/B/E/S. The equal-weighted average is a simple arithmetic average of the individual firm risk premia while the value-weighted average is based on the market cap as of the most recent year-end.

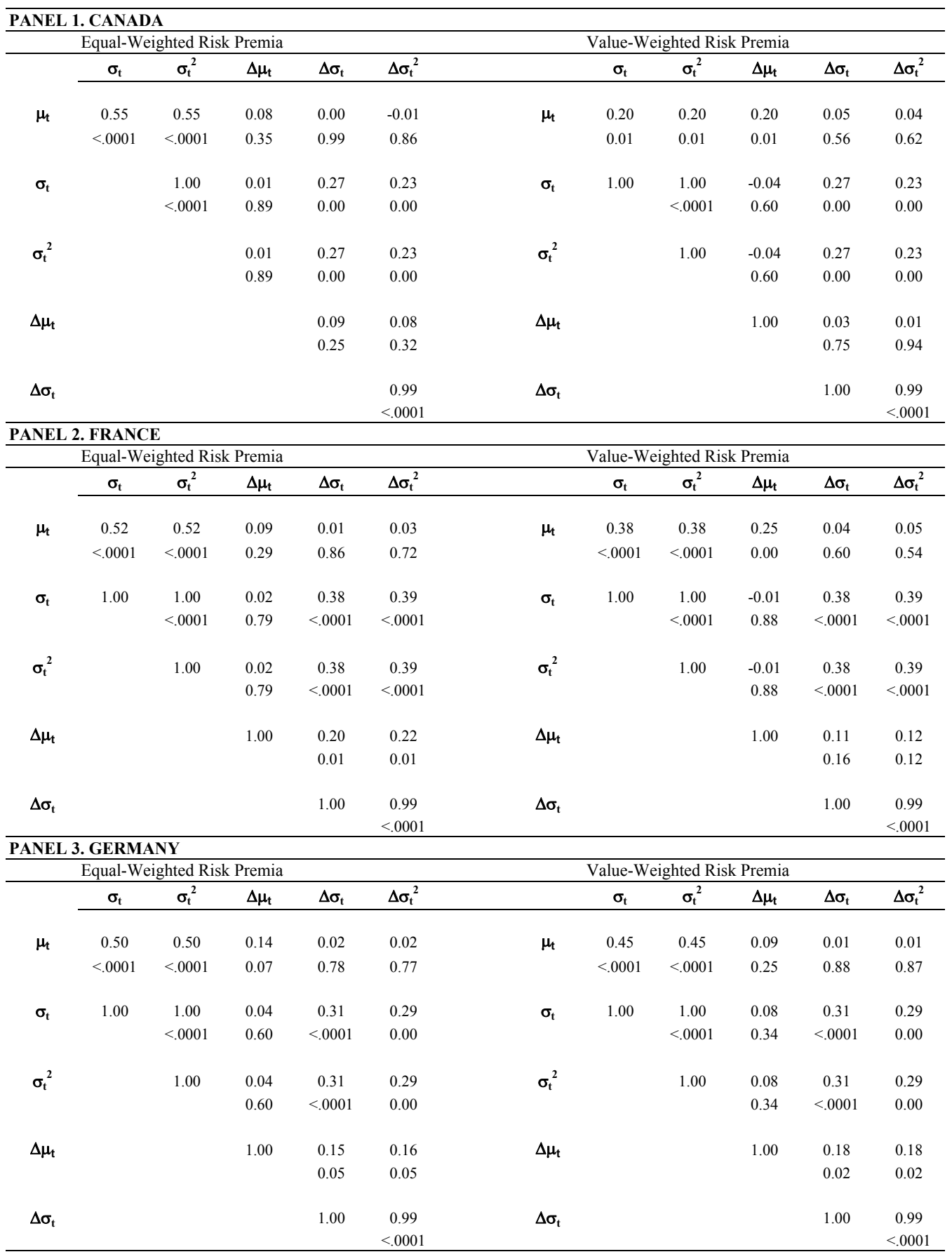


Table 6 continued

PANEL 4. ITALY

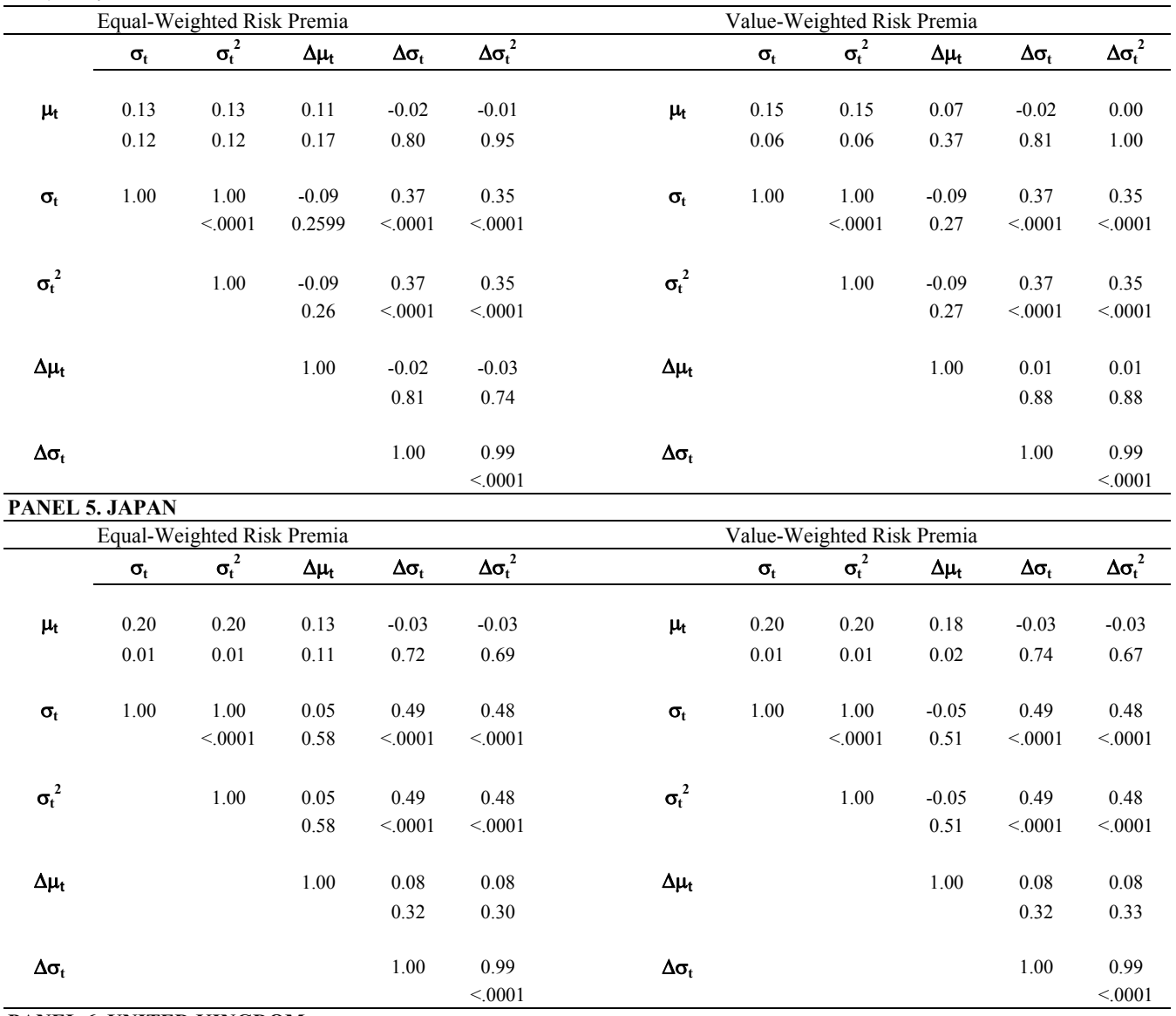

PANEL 6. UNITED KINGDOM

\begin{tabular}{|c|c|c|c|c|c|c|c|c|c|c|c|}
\hline & Equal-W & ghted Ri & Premia & & & & Value-W & ighted R & Premia & & \\
\hline & $\sigma_{\mathrm{t}}$ & $\sigma_{t}^{2}$ & $\Delta \mu_{\mathrm{t}}$ & $\Delta \sigma_{t}$ & $\Delta \sigma_{t}^{2}$ & & $\sigma_{\mathrm{t}}$ & $\sigma_{t}^{2}$ & $\Delta \mu_{\mathrm{t}}$ & $\Delta \sigma_{t}$ & $\Delta \sigma_{t}^{2}$ \\
\hline$\mu_{t}$ & 0.60 & 0.60 & 0.10 & 0.02 & 0.02 & $\mu_{\mathrm{t}}$ & 0.44 & 0.44 & 0.28 & 0.07 & 0.07 \\
\hline & $<.0001$ & $<.0001$ & 0.21 & 0.80 & 0.84 & & $<.0001$ & $<.0001$ & 0.00 & 0.37 & 0.42 \\
\hline$\sigma_{t}$ & 1.00 & 1.00 & 0.06 & 0.36 & 0.36 & $\sigma_{t}$ & 1.00 & 1.00 & 0.08 & 0.36 & 0.36 \\
\hline & & $<.0001$ & 0.46 & $<.0001$ & $<.0001$ & & & $<.0001$ & 0.31 & $<.0001$ & $<.0001$ \\
\hline$\sigma_{t}^{2}$ & & 1.00 & 0.06 & 0.36 & 0.36 & $\sigma_{t}^{2}$ & & 1.00 & 0.08 & 0.36 & 0.36 \\
\hline & & & 0.46 & $<.0001$ & $<.0001$ & & & & 0.31 & $<.0001$ & $<.0001$ \\
\hline$\Delta \mu_{\mathrm{t}}$ & & & 1.00 & 0.32 & 0.33 & $\Delta \mu_{\mathrm{t}}$ & & & 1.00 & 0.21 & 0.23 \\
\hline & & & & $<.0001$ & $<.0001$ & & & & & 0.01 & 0.00 \\
\hline$\Delta \sigma_{\mathrm{t}}$ & & & & 1.00 & 0.99 & $\Delta \sigma_{\mathrm{t}}$ & & & & 1.00 & 0.99 \\
\hline & & & & & $<.0001$ & & & & & & $<.0001$ \\
\hline PANEI & 7. UNITE & STATE & & & & & & & & & \\
\hline & Equal-W & ghted Ri & Premia & & & & Value-W & ghted $\mathrm{R}$ & Premia & & \\
\hline & $\sigma_{\mathrm{t}}$ & $\sigma_{t}^{2}$ & $\Delta \mu_{\mathrm{t}}$ & $\Delta \sigma_{\mathrm{t}}$ & $\Delta \sigma_{t}^{2}$ & & $\sigma_{t}$ & $\sigma_{t}^{2}$ & $\Delta \mu_{\mathrm{t}}$ & $\Delta \sigma_{t}$ & $\Delta \sigma_{t}^{2}$ \\
\hline$\mu_{\mathrm{t}}$ & 0.37 & 0.37 & 0.18 & 0.00 & 0.00 & $\mu_{\mathrm{t}}$ & 0.10 & 0.10 & 0.29 & -0.03 & -0.03 \\
\hline & $<.0001$ & $<.0001$ & 0.00 & 0.95 & 0.96 & & 0.12 & 0.12 & $<.0001$ & 0.60 & 0.63 \\
\hline$\sigma_{t}$ & 1.00 & 1.00 & 0.06 & 0.31 & 0.29 & $\sigma_{t}$ & 1.00 & 1.00 & 0.04 & 0.31 & 0.29 \\
\hline & & $<.0001$ & 0.35 & $<.0001$ & $<.0001$ & & & $<.0001$ & 0.50 & $<.0001$ & $<.0001$ \\
\hline$\sigma_{t}^{2}$ & & 1.00 & 0.06 & 0.31 & 0.29 & $\sigma_{t}^{2}$ & & 1.00 & 0.04 & 0.31 & 0.29 \\
\hline & & & 0.35 & $<.0001$ & $<.0001$ & & & & 0.50 & $<.0001$ & $<.0001$ \\
\hline$\Delta \mu_{\mathrm{t}}$ & & & 1.00 & 0.11 & 0.11 & $\Delta \mu_{t}$ & & & 1.00 & 0.03 & 0.02 \\
\hline & & & & 0.08 & 0.07 & & & & & 0.68 & 0.70 \\
\hline$\Delta \sigma_{t}$ & & & & 1.00 & $\begin{array}{c}0.99 \\
<.0001\end{array}$ & $\Delta \sigma_{t}$ & & & & 1.00 & $\begin{array}{c}0.99 \\
<.0001\end{array}$ \\
\hline
\end{tabular}


Table 7

\section{U.S. Implied Premium Regressed on U.S. Implied Volatility (1986-2002)}

This table reports the slope coefficients from the time series regressions in equations (24) through (28) for

the U.S. stock market between January 1986 through December 2002. Return volatility $\sigma_{t}$ is the implied volatility from month $t$, measured as the VXO index. The $t$-statistics are adjusted for residual autocorrelation using the Newey-West correction.

\begin{tabular}{|c|c|c|c|c|}
\hline & \multicolumn{2}{|c|}{$\overline{\sigma^{2}}$} & \multicolumn{2}{|c|}{$\sigma$} \\
\hline & EW & VW & EW & VW \\
\hline & \multicolumn{4}{|c|}{ Equation (24): $\mu_{t}=a+b \sigma_{t}^{(2)}+e_{t}$} \\
\hline$\hat{b}$ & 0.11 & 0.04 & 0.06 & 0.02 \\
\hline$t$ & 4.37 & 1.89 & 3.95 & 1.21 \\
\hline \multirow[t]{2}{*}{$R^{2}$} & 0.25 & 0.06 & 0.27 & 0.03 \\
\hline & \multicolumn{4}{|c|}{ Equation (25): $\mu_{t}=a+b \sigma_{t}^{(2)}+c \mu_{t-1}+e_{t}$} \\
\hline$\hat{b}$ & 0.06 & 0.04 & 0.03 & 0.02 \\
\hline$t$ & 8.32 & 6.19 & 6.60 & 4.45 \\
\hline \multirow[t]{2}{*}{$R^{2}$} & 0.80 & 0.75 & 0.78 & 0.72 \\
\hline & \multicolumn{4}{|c|}{ Equation (26): $\mu_{t}=a+b \Delta \sigma_{t}^{(2)}+c \mu_{t-1}+e_{t}$} \\
\hline$\hat{b}$ & 0.08 & 0.07 & 0.06 & 0.05 \\
\hline$t$ & 9.63 & 9.00 & 9.42 & 9.15 \\
\hline \multirow[t]{2}{*}{$R^{2}$} & 0.81 & 0.78 & 0.81 & 0.78 \\
\hline & \multicolumn{4}{|c|}{ Equation (27): $\Delta \mu_{t}=a+b \Delta \sigma_{t}^{(2)}+e_{t}$} \\
\hline$\hat{b}$ & 0.09 & 0.07 & 0.06 & 0.05 \\
\hline$t$ & 10.47 & 9.77 & 10.17 & 9.84 \\
\hline \multirow[t]{2}{*}{$R^{2}$} & 0.35 & 0.32 & 0.34 & 0.32 \\
\hline & \multicolumn{4}{|c|}{ Equation (28): $\epsilon_{\mu, t}=a+b \epsilon_{V, t}+e_{t}$} \\
\hline$\hat{b}$ & 0.09 & 0.08 & 0.06 & 0.05 \\
\hline$t$ & 11.24 & 9.64 & 10.37 & 9.24 \\
\hline$R^{2}$ & 0.38 & 0.31 & 0.35 & 0.29 \\
\hline
\end{tabular}


Table 8

\section{U.S. Implied Premium Regressed on U.S. Implied Volatility (1986-2002), Controlling for Hedging Demands}

This table reports the slope coefficients from the time series regressions in the counterparts of equations (24) through (28) for the U.S. stock market between January 1986 through December 2002. Return volatility $\sigma_{t}$ is the implied volatility from month $t$, measured as the VXO index. Hedging demands $\left(H_{t}\right)$ are proxied by five variables: the excess return on the 30-year Treasury bond, the default spread, the term spread, the detrended risk-free rate, and the dividend-price ratio. The $t$-statistics are adjusted for residual autocorrelation using the Newey-West correction.

\begin{tabular}{cccccc}
\hline & \multicolumn{2}{c}{$\sigma^{2}$} & & \multicolumn{2}{c}{$\sigma$} \\
\cline { 2 - 3 } \cline { 5 - 6 } & $\mathrm{EW}$ & $\mathrm{VW}$ & & $\mathrm{EW}$ & $\mathrm{VW}$ \\
\hline & Eq. & $(24)$ & with hedging demands: & $\mu_{t}=a+b \sigma_{t}^{(2)}+h H_{t}+e_{t}$ \\
$\hat{b}$ & 0.09 & 0.04 & & 0.05 & 0.01 \\
$t$ & 4.58 & 1.77 & & 3.89 & 1.14 \\
$R^{2}$ & 0.46 & 0.17 & & 0.44 & 0.16 \\
\hline
\end{tabular}

Eq. (25) with hedging demands: $\mu_{t}=a+b \sigma_{t}^{(2)}+c \mu_{t-1}+h H_{t}+e_{t}$

$\begin{array}{lllll}\hat{b} & 0.06 & 0.04 & 0.03 & 0.02\end{array}$

$\begin{array}{lllll}t & 8.40 & 6.50 & 7.06 & 5.40\end{array}$

$\begin{array}{lllll}R^{2} & 0.86 & 0.82 & 0.85 & 0.81\end{array}$

\begin{tabular}{ccccc}
\hline Eq. & (26) & with hedging demands: & \multicolumn{2}{c}{$\mu_{t}=a+b \Delta \sigma_{t}^{(2)}+c \mu_{t-1}+h H_{t}+e_{t}$} \\
$\hat{b}$ & 0.07 & 0.06 & 0.05 & 0.04 \\
$t$ & 9.03 & 8.71 & 9.42 & 9.51 \\
$R^{2}$ & 0.86 & 0.84 & 0.87 & 0.85 \\
\hline
\end{tabular}

Eq. (27) with hedging demands: $\Delta \mu_{t}=a+b \Delta \sigma_{t}^{(2)}+h \Delta H_{t}+e_{t}$

$\begin{array}{ccccc}\hat{b} & 0.03 & 0.02 & 0.02 & 0.02 \\ t & 4.21 & 3.42 & 4.22 & 3.80 \\ R^{2} & 0.68 & 0.65 & 0.69 & 0.65\end{array}$

Eq. (28) with hedging demands: $\epsilon_{\mu, t}=a+b \epsilon_{V, t}+h \epsilon_{H, t}+e_{t}$

$\begin{array}{lllll}\hat{b} & 0.08 & 0.06 & 0.05 & 0.04\end{array}$

$\begin{array}{lllll}t & 7.47 & 5.97 & 6.56 & 5.53\end{array}$

$\begin{array}{lllll}R^{2} & 0.41 & 0.35 & 0.38 & 0.34\end{array}$ 
Table 9

Aggregate G-7 Risk Premia and World Market Volatility

The table contains the results of time-series regressions using monthly data over the period July 1990 to December 2002. $\mu_{t}$ is the 'G-7 risk premium', computed as a simple cross-sectional average of the annual implied risk premiums in the G-7 countries. $\sigma_{t}$ is the 'world volatility', computed as the square root of 252 times the standard deviation of the daily returns on the market, computed over the previous month, where the 'market' is the MSCI World index. $\varepsilon_{\mu t}\left(\varepsilon_{\sigma t}\right)$ is the residual from an AR (1) model for the implied premium (standard deviation). Data for the United States are obtained from COMPUSTAT, CRSP, and I/B/E/S. Data for other countries are obtained from Worldscope, Datastream, and I/B/E/S. The numbers in parentheses are t-statistics computed using the Newey-West correction with 12 lags of autocorrelation in the first specification and 1 lag of autocorrelation in other specifications and also corrected for heteroskedasticity.

\begin{tabular}{|c|c|c|c|c|c|c|c|c|c|c|c|c|c|}
\hline \multicolumn{14}{|c|}{$\begin{array}{l}\text { PANEL 1A. World Regressions with Month-End World Volatility and Average EW Risk Premia } \\
\end{array}$} \\
\hline & Intercept & $\sigma_{t}^{2}$ & $\Delta \sigma_{t}^{2}$ & $\mu_{\mathrm{t}-1}$ & $\varepsilon_{\sigma}^{2} t$ & Adj. $R^{2}$ & & Intercept & $\sigma_{t}$ & $\Delta \sigma_{t}$ & $\mu_{\mathrm{t}-1}$ & $\varepsilon_{\sigma \mathrm{t}}$ & Adj. $R^{2}$ \\
\hline$\mu_{t}$ & $\begin{array}{c}0.05 \\
(8.40)\end{array}$ & $\begin{array}{c}0.67 \\
(3.67)\end{array}$ & & & & $16.71 \%$ & $\mu_{t}$ & $\begin{array}{c}0.03 \\
(5.11)\end{array}$ & $\begin{array}{c}0.23 \\
(3.27)\end{array}$ & & & & $19.38 \%$ \\
\hline$\mu_{t}$ & $\begin{array}{c}0.00 \\
(1.06)\end{array}$ & $\begin{array}{c}0.10 \\
(3.65)\end{array}$ & & $\begin{array}{c}0.97 \\
(59.54)\end{array}$ & & $97.90 \%$ & $\mu_{t}$ & $\begin{array}{c}0.00 \\
(-0.71)\end{array}$ & $\begin{array}{c}0.03 \\
(3.19)\end{array}$ & & $\begin{array}{c}0.97 \\
(58.41)\end{array}$ & & $97.82 \%$ \\
\hline$\mu_{t}$ & $\begin{array}{c}0.00 \\
(1.39)\end{array}$ & & $\begin{array}{c}0.09 \\
(2.70)\end{array}$ & $\begin{array}{c}0.99 \\
(73.82)\end{array}$ & & $97.83 \%$ & $\mu_{t}$ & $\begin{array}{c}0.00 \\
(1.42)\end{array}$ & & $\begin{array}{c}0.03 \\
(2.43)\end{array}$ & $\begin{array}{c}0.99 \\
(71.96)\end{array}$ & & $97.77 \%$ \\
\hline$\Delta \mu_{\mathrm{t}}$ & $\begin{array}{c}0.00 \\
(1.88)\end{array}$ & & $\begin{array}{c}0.09 \\
(2.72)\end{array}$ & & & $10.89 \%$ & $\Delta \mu_{\mathrm{t}}$ & $\begin{array}{c}0.00 \\
(1.85)\end{array}$ & & $\begin{array}{c}0.03 \\
(2.45)\end{array}$ & & & $8.25 \%$ \\
\hline$\varepsilon_{\mu \mathrm{t}}$ & $\begin{array}{c}0.00 \\
(0.00) \\
\end{array}$ & & & & $\begin{array}{c}0.12 \\
(3.49) \\
\end{array}$ & $15.31 \%$ & $\varepsilon_{\mu \mathrm{t}}$ & $\begin{array}{c}0.00 \\
(0.00) \\
\end{array}$ & & & & $\begin{array}{c}0.03 \\
(3.04) \\
\end{array}$ & $11.61 \%$ \\
\hline \multicolumn{14}{|c|}{ PANEL 1B. World Regressions with Month-End World Volatility and Average VW Risk Premia } \\
\hline & Intercept & $\sigma_{t}^{2}$ & $\Delta \sigma_{t}^{2}$ & $\mu_{\mathrm{t}-1}$ & $\varepsilon_{\sigma t}^{2}$ & Adj. $R^{2}$ & & Intercept & $\sigma_{\mathrm{t}}$ & $\Delta \sigma_{t}$ & $\mu_{\mathrm{t}-1}$ & $\varepsilon_{\sigma t}$ & Adj. $R^{2}$ \\
\hline$\mu_{t}$ & $\begin{array}{c}0.02 \\
(7.87)\end{array}$ & $\begin{array}{c}0.30 \\
(2.39)\end{array}$ & & & & $11.70 \%$ & $\mu_{\mathrm{t}}$ & $\begin{array}{c}0.02 \\
(3.75)\end{array}$ & $\begin{array}{c}0.09 \\
(2.01)\end{array}$ & & & & $11.52 \%$ \\
\hline$\mu_{\mathrm{t}}$ & $\begin{array}{c}0.00 \\
(1.41)\end{array}$ & $\begin{array}{c}0.05 \\
(2.52)\end{array}$ & & $\begin{array}{c}0.95 \\
(49.27)\end{array}$ & & $95.29 \%$ & $\mu_{t}$ & $\begin{array}{c}0.00 \\
(-0.12)\end{array}$ & $\begin{array}{c}0.01 \\
(2.17)\end{array}$ & & $\begin{array}{c}0.96 \\
(49.48)\end{array}$ & & $95.19 \%$ \\
\hline$\mu_{\mathrm{t}}$ & $\begin{array}{c}0.00 \\
(2.18)\end{array}$ & & $\begin{array}{c}0.03 \\
(1.18)\end{array}$ & $\begin{array}{c}0.97 \\
(51.23)\end{array}$ & & $95.05 \%$ & $\mu_{\mathrm{t}}$ & $\begin{array}{c}0.00 \\
(2.22)\end{array}$ & & $\begin{array}{c}0.01 \\
(0.94)\end{array}$ & $\begin{array}{c}0.97 \\
(50.91)\end{array}$ & & $95.00 \%$ \\
\hline$\Delta \mu_{\mathrm{t}}$ & $\begin{array}{c}0.00 \\
(1.66)\end{array}$ & & $\begin{array}{c}0.03 \\
(1.24)\end{array}$ & & & $2.28 \%$ & $\Delta \mu_{\mathrm{t}}$ & $\begin{array}{c}0.00 \\
(1.64)\end{array}$ & & $\begin{array}{c}0.01 \\
(0.98)\end{array}$ & & & $1.12 \%$ \\
\hline$\varepsilon_{\mu \mathrm{t}}$ & $\begin{array}{c}0.00 \\
(0.00) \\
\end{array}$ & & & & $\begin{array}{c}0.05 \\
(1.92) \\
\end{array}$ & $5.37 \%$ & $\varepsilon_{\mu \mathrm{t}}$ & $\begin{array}{c}0.00 \\
(0.00) \\
\end{array}$ & & & & $\begin{array}{c}0.02 \\
(1.49) \\
\end{array}$ & $3.28 \%$ \\
\hline \multicolumn{14}{|c|}{ PANEL 2A. World Regressions with Mid-Month World Volatility and Average EW Risk Premia } \\
\hline & Intercept & $\sigma_{t}^{2}$ & $\Delta \sigma_{t}^{2}$ & $\mu_{\mathrm{t}-1}$ & $\varepsilon_{\sigma t}^{2}$ & Adj. $R^{2}$ & & Intercept & $\sigma_{t}$ & $\Delta \sigma_{t}$ & $\mu_{\mathrm{t}-1}$ & $\varepsilon_{\sigma t}$ & Adj. $R^{2}$ \\
\hline$\mu_{\mathrm{t}}$ & $\begin{array}{c}0.05 \\
(8.21)\end{array}$ & $\begin{array}{c}0.60 \\
(3.98)\end{array}$ & & & & $15.25 \%$ & $\mu_{t}$ & $\begin{array}{c}0.03 \\
(5.68)\end{array}$ & $\begin{array}{c}0.22 \\
(3.26)\end{array}$ & & & & $18.47 \%$ \\
\hline$\mu_{\mathrm{t}}$ & $\begin{array}{c}0.00 \\
(1.37)\end{array}$ & $\begin{array}{c}0.04 \\
(1.93)\end{array}$ & & $\begin{array}{c}0.98 \\
(71.19)\end{array}$ & & $97.63 \%$ & $\mu_{t}$ & $\begin{array}{c}0.00 \\
(0.30)\end{array}$ & $\begin{array}{c}0.01 \\
(1.91)\end{array}$ & & $\begin{array}{c}0.98 \\
(70.66)\end{array}$ & & $97.62 \%$ \\
\hline$\mu_{t}$ & $\begin{array}{c}0.00 \\
(1.54)\end{array}$ & & $\begin{array}{c}0.05 \\
(2.06)\end{array}$ & $\begin{array}{c}0.99 \\
(69.67)\end{array}$ & & $97.65 \%$ & $\mu_{t}$ & $\begin{array}{c}0.00 \\
(1.54)\end{array}$ & & $\begin{array}{c}0.02 \\
(2.02)\end{array}$ & $\begin{array}{c}0.99 \\
(69.40)\end{array}$ & & $97.64 \%$ \\
\hline$\Delta \mu_{\mathrm{t}}$ & $\begin{array}{c}0.00 \\
(1.86)\end{array}$ & & $\begin{array}{c}0.05 \\
(2.06)\end{array}$ & & & $3.34 \%$ & $\Delta \mu_{\mathrm{t}}$ & $\begin{array}{c}0.00 \\
(1.85)\end{array}$ & & $\begin{array}{c}0.02 \\
(2.02)\end{array}$ & & & $3.03 \%$ \\
\hline$\varepsilon_{\mu \mathrm{t}}$ & $\begin{array}{c}0.00 \\
(0.00)\end{array}$ & & & & $\begin{array}{c}0.06 \\
(2.03)\end{array}$ & $3.63 \%$ & $\varepsilon_{\mu \mathrm{t}}$ & $\begin{array}{c}0.00 \\
(0.00)\end{array}$ & & & & $\begin{array}{c}0.02 \\
(2.00)\end{array}$ & $3.45 \%$ \\
\hline \multicolumn{14}{|c|}{ PANEL 2B. World Regressions with Mid-Month World Volatility and Average VW Risk Premia } \\
\hline & Intercept & $\sigma_{t}^{2}$ & $\Delta \sigma_{t}^{2}$ & $\mu_{\mathrm{t}-1}$ & $\varepsilon_{\sigma t}^{2}$ & Adj. $R^{2}$ & & Intercept & $\sigma_{t}$ & $\Delta \sigma_{t}$ & $\mu_{\mathrm{t}-1}$ & $\varepsilon_{\sigma t}$ & Adj. $R^{2}$ \\
\hline$\mu_{t}$ & $\begin{array}{c}0.02 \\
(7.69)\end{array}$ & $\begin{array}{c}0.28 \\
(2.80)\end{array}$ & & & & $11.51 \%$ & $\mu_{\mathrm{t}}$ & $\begin{array}{c}0.02 \\
(4.14)\end{array}$ & $\begin{array}{c}0.09 \\
(2.09)\end{array}$ & & & & $11.23 \%$ \\
\hline$\mu_{t}$ & $\begin{array}{c}0.00 \\
(2.00)\end{array}$ & $\begin{array}{c}0.02 \\
(1.06)\end{array}$ & & $\begin{array}{c}0.96 \\
(53.45)\end{array}$ & & $94.97 \%$ & $\mu_{\mathrm{t}}$ & $\begin{array}{c}0.00 \\
(0.77)\end{array}$ & $\begin{array}{c}0.01 \\
(1.15)\end{array}$ & & $\begin{array}{c}0.96 \\
(53.54)\end{array}$ & & $94.98 \%$ \\
\hline$\mu_{\mathrm{t}}$ & $\begin{array}{c}0.00 \\
(2.38)\end{array}$ & & $\begin{array}{c}0.01 \\
(0.76)\end{array}$ & $\begin{array}{c}0.97 \\
(52.28)\end{array}$ & & $94.95 \%$ & $\mu_{t}$ & $\begin{array}{c}0.00 \\
(2.38)\end{array}$ & & $\begin{array}{c}0.01 \\
(0.95)\end{array}$ & $\begin{array}{c}0.97 \\
(52.31)\end{array}$ & & $94.96 \%$ \\
\hline$\Delta \mu_{\mathrm{t}}$ & $\begin{array}{c}0.00 \\
(1.64)\end{array}$ & & $\begin{array}{c}0.02 \\
(0.76)\end{array}$ & & & $0.05 \%$ & $\Delta \mu_{\mathrm{t}}$ & $\begin{array}{c}0.00 \\
(1.64)\end{array}$ & & $\begin{array}{c}0.01 \\
(0.95)\end{array}$ & & & $0.25 \%$ \\
\hline$\varepsilon_{\mu \mathrm{t}}$ & $\begin{array}{c}0.00 \\
(0.00) \\
\end{array}$ & & & & $\begin{array}{c}0.02 \\
(0.96)\end{array}$ & $0.51 \%$ & $\varepsilon_{\mu \mathrm{t}}$ & $\begin{array}{c}0.00 \\
(0.00)\end{array}$ & & & & $\begin{array}{c}0.01 \\
(1.11)\end{array}$ & $0.72 \%$ \\
\hline
\end{tabular}


Table 10

Country Risk Premia and World Market Volatility

The table contains the results of time-series regressions using monthly data over the period July 1990 to December 2002 . $\mu_{\mathrm{t}}$ is the individual country implied risk premium. $\sigma_{t}$ is the 'world volatility', computed as the square root of 252 times the standard deviation of the daily returns on the market, computed over the previous month, where the 'market' is the MSCI World index. $\varepsilon_{\mu \mathrm{t}}\left(\varepsilon_{\sigma \mathrm{\sigma t}}\right)$ is the residual from an AR (1) model for the implied premium (standard deviation). Data for the United States are obtained from COMPUSTAT, CRSP, and I/B/E/S. Data for other countries are obtained from Worldscope, Datastream, and I/B/E/S. The numbers in parentheses are t-statistics computed using the Newey-West correction with 12 lags of autocorrelation in the first specification and 1 lag of autocorrelation in other specifications and also corrected for heteroskedasticity.

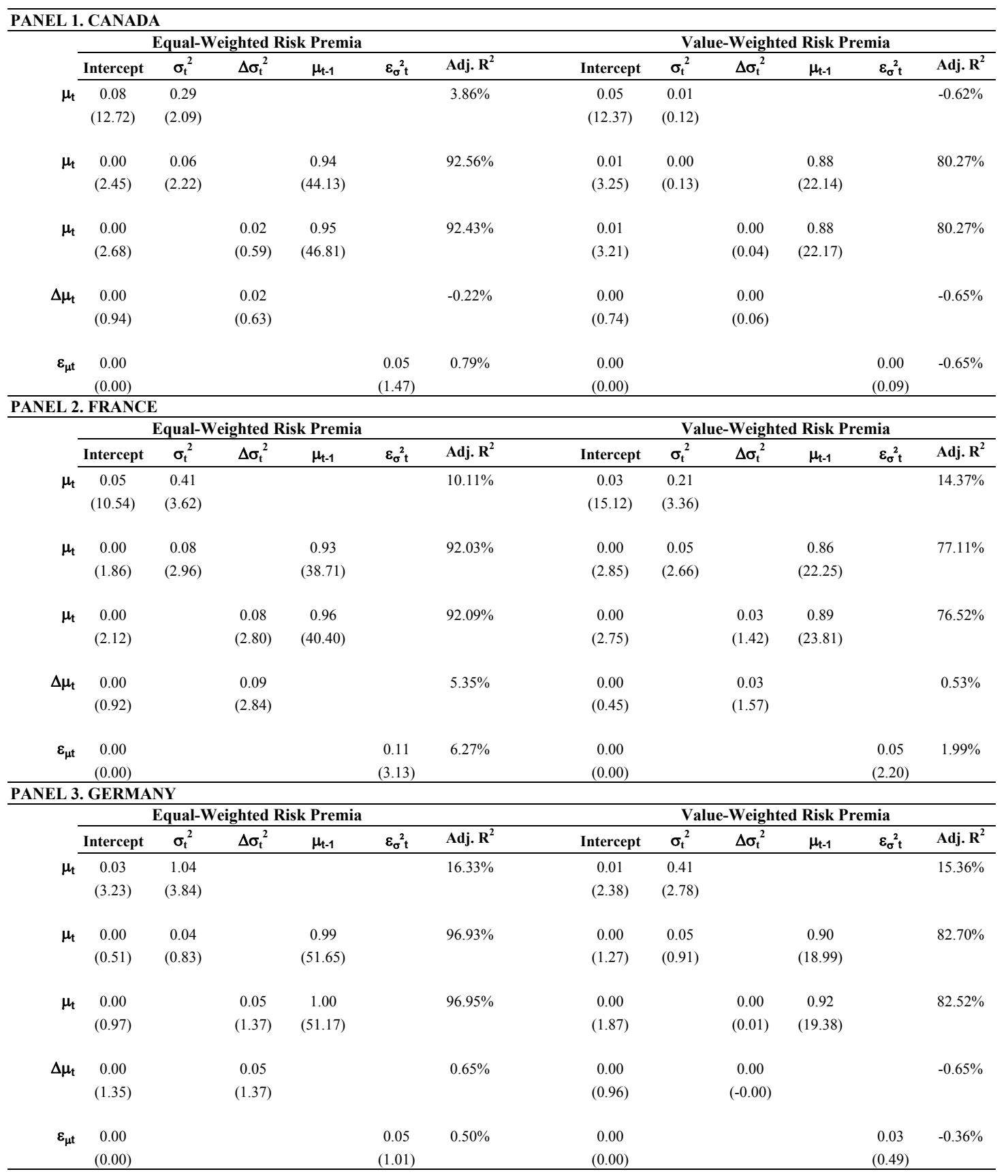




\begin{tabular}{|c|c|c|c|c|c|c|c|c|c|c|c|c|}
\hline \multicolumn{13}{|c|}{ PANEL 4. ITALY } \\
\hline & \multicolumn{5}{|c|}{ Equal-Weighted Risk Premia } & \multirow[b]{2}{*}{ Adj. $R^{2}$} & \multicolumn{6}{|c|}{ Value-Weighted Risk Premia } \\
\hline & Intercept & $\sigma_{t}^{2}$ & $\Delta \sigma_{t}^{2}$ & $\mu_{\mathrm{t}-1}$ & $\varepsilon_{\sigma t}^{2}$ & & Intercept & $\sigma_{t}^{2}$ & $\Delta \sigma_{\mathrm{t}}^{2}$ & $\mu_{t-1}$ & $\varepsilon_{\sigma t}^{2}$ & Adj. $R^{2}$ \\
\hline$\mu_{\mathrm{t}}$ & $\begin{array}{c}0.03 \\
(2.95)\end{array}$ & $\begin{array}{c}0.72 \\
(2.64)\end{array}$ & & & & $9.26 \%$ & $\begin{array}{c}0.00 \\
(-0.40)\end{array}$ & $\begin{array}{c}0.55 \\
(2.73)\end{array}$ & & & & $7.67 \%$ \\
\hline$\mu_{\mathrm{t}}$ & $\begin{array}{c}0.00 \\
(1.17)\end{array}$ & $\begin{array}{c}0.02 \\
(0.49)\end{array}$ & & $\begin{array}{c}0.97 \\
(37.38)\end{array}$ & & $93.12 \%$ & $\begin{array}{c}0.00 \\
(0.79)\end{array}$ & $\begin{array}{c}0.02 \\
(0.46)\end{array}$ & & $\begin{array}{c}0.95 \\
(36.65)\end{array}$ & & $93.27 \%$ \\
\hline$\mu_{\mathrm{t}}$ & $\begin{array}{c}0.00 \\
(1.41)\end{array}$ & & $\begin{array}{c}-0.01 \\
(-0.31)\end{array}$ & $\begin{array}{c}0.97 \\
(38.97)\end{array}$ & & $93.11 \%$ & $\begin{array}{c}0.00 \\
(1.38)\end{array}$ & & $\begin{array}{c}-0.01 \\
(-0.31)\end{array}$ & $\begin{array}{c}0.96 \\
(39.27)\end{array}$ & & $93.26 \%$ \\
\hline$\Delta \mu_{\mathrm{t}}$ & $\begin{array}{c}0.00 \\
(1.07)\end{array}$ & & $\begin{array}{c}-0.01 \\
(-0.32)\end{array}$ & & & $-0.62 \%$ & $\begin{array}{c}0.00 \\
(1.17)\end{array}$ & & $\begin{array}{c}-0.01 \\
(-0.31)\end{array}$ & & & $-0.62 \%$ \\
\hline$\varepsilon_{\mu \mathrm{t}}$ & $\begin{array}{c}0.00 \\
(-0.00)\end{array}$ & & & & $\begin{array}{c}0.01 \\
(0.10) \\
\end{array}$ & $-0.67 \%$ & $\begin{array}{c}0.00 \\
(-0.00) \\
\end{array}$ & & & & $\begin{array}{c}0.01 \\
(0.12) \\
\end{array}$ & $-0.67 \%$ \\
\hline \multicolumn{13}{|c|}{ PANEL 5. JAPAN } \\
\hline \multicolumn{7}{|c|}{\begin{tabular}{cc} 
Equal-Weighted Risk Premia \\
\cline { 2 - 2 }
\end{tabular}} & \multicolumn{6}{|c|}{ Value-Weighted Risk Premia } \\
\hline & Intercept & $\sigma_{t}^{2}$ & $\Delta \sigma_{t}^{2}$ & $\mu_{\mathrm{t}-1}$ & $\varepsilon_{\sigma t}^{2}$ & Adj. $\mathbf{R}^{2}$ & Intercept & $\sigma_{t}^{2}$ & $\Delta \sigma_{\mathrm{t}}^{2}$ & $\mu_{\mathrm{t}-1}$ & $\varepsilon_{\sigma t}^{2}$ & Adj. $R^{2}$ \\
\hline$\mu_{\mathrm{t}}$ & $\begin{array}{c}0.04 \\
(2.96)\end{array}$ & $\begin{array}{c}0.88 \\
(3.32)\end{array}$ & & & & $7.84 \%$ & $\begin{array}{c}0.02 \\
(3.01)\end{array}$ & $\begin{array}{c}0.37 \\
(1.87)\end{array}$ & & & & $3.75 \%$ \\
\hline$\mu_{\mathrm{t}}$ & $\begin{array}{c}0.00 \\
(1.23)\end{array}$ & $\begin{array}{c}0.03 \\
(0.93)\end{array}$ & & $\begin{array}{c}0.99 \\
(84.99)\end{array}$ & & $98.18 \%$ & $\begin{array}{c}0.00 \\
(1.46)\end{array}$ & $\begin{array}{c}0.03 \\
(0.95)\end{array}$ & & $\begin{array}{c}0.97 \\
(59.91)\end{array}$ & & $95.73 \%$ \\
\hline$\mu_{\mathrm{t}}$ & $\begin{array}{c}0.00 \\
(2.11)\end{array}$ & & $\begin{array}{c}0.02 \\
(0.53)\end{array}$ & $\begin{array}{c}0.99 \\
(89.28)\end{array}$ & & $98.17 \%$ & $\begin{array}{c}0.00 \\
(2.34)\end{array}$ & & $\begin{array}{c}0.01 \\
(0.49)\end{array}$ & $\begin{array}{c}0.98 \\
(61.29)\end{array}$ & & $95.71 \%$ \\
\hline$\Delta \mu_{\mathrm{t}}$ & $\begin{array}{c}0.00 \\
(1.77)\end{array}$ & & $\begin{array}{c}0.02 \\
(0.54)\end{array}$ & & & $-0.50 \%$ & $\begin{array}{c}0.00 \\
(1.48)\end{array}$ & & $\begin{array}{c}0.01 \\
(0.51)\end{array}$ & & & $-0.56 \%$ \\
\hline$\varepsilon_{\mu t}$ & $\begin{array}{c}0.00 \\
(0.00)\end{array}$ & & & & $\begin{array}{c}0.03 \\
(0.81)\end{array}$ & $-0.21 \%$ & $\begin{array}{c}0.00 \\
(0.00)\end{array}$ & & & & $\begin{array}{c}0.02 \\
(0.88)\end{array}$ & $-0.32 \%$ \\
\hline \multicolumn{13}{|c|}{ PANEL 6. UNITED KINGDOM } \\
\hline \multicolumn{7}{|c|}{\begin{tabular}{cc} 
Equal-Weighted Risk Premia \\
\cline { 2 - 2 }
\end{tabular}} & \multicolumn{6}{|c|}{ Value-Weighted Risk Premia } \\
\hline & Intercept & $\sigma_{t}^{2}$ & $\Delta \sigma_{t}^{2}$ & $\mu_{\mathrm{t}-1}$ & $\varepsilon_{\sigma}^{2} t$ & Adj. $R^{2}$ & Intercept & $\sigma_{t}^{2}$ & $\Delta \sigma_{t}^{2}$ & $\mu_{t-1}$ & $\varepsilon_{\sigma t}^{2}$ & Adj. $R^{2}$ \\
\hline$\mu_{\mathrm{t}}$ & $\begin{array}{c}0.06 \\
(13.07)\end{array}$ & $\begin{array}{c}0.62 \\
(4.77)\end{array}$ & & & & $21.50 \%$ & $\begin{array}{c}0.02 \\
(13.57)\end{array}$ & $\begin{array}{c}0.26 \\
(5.33)\end{array}$ & & & & $17.49 \%$ \\
\hline$\mu_{\mathrm{t}}$ & $\begin{array}{c}0.00 \\
(1.90)\end{array}$ & $\begin{array}{c}0.10 \\
(3.38)\end{array}$ & & $\begin{array}{c}0.94 \\
(37.90)\end{array}$ & & $93.46 \%$ & $\begin{array}{c}0.01 \\
(2.71)\end{array}$ & $\begin{array}{c}0.11 \\
(3.01)\end{array}$ & & $\begin{array}{c}0.72 \\
(7.58)\end{array}$ & & $62.28 \%$ \\
\hline$\mu_{\mathrm{t}}$ & $\begin{array}{c}0.00 \\
(1.52)\end{array}$ & & $\begin{array}{c}0.10 \\
(4.05)\end{array}$ & $\begin{array}{c}0.97 \\
(46.49)\end{array}$ & & $93.61 \%$ & $\begin{array}{c}0.01 \\
(2.62)\end{array}$ & & $\begin{array}{c}0.06 \\
(1.73)\end{array}$ & $\begin{array}{c}0.79 \\
(9.60)\end{array}$ & & $60.53 \%$ \\
\hline$\Delta \mu_{\mathrm{t}}$ & $\begin{array}{c}0.00 \\
(0.98)\end{array}$ & & $\begin{array}{c}0.11 \\
(4.25)\end{array}$ & & & $8.76 \%$ & $\begin{array}{c}0.00 \\
(0.52)\end{array}$ & & $\begin{array}{c}0.07 \\
(1.86)\end{array}$ & & & $2.28 \%$ \\
\hline$\varepsilon_{\mu \mathrm{t}}$ & $\begin{array}{c}0.00 \\
(0.00) \\
\end{array}$ & & & & $\begin{array}{c}0.12 \\
(4.00) \\
\end{array}$ & $9.13 \%$ & $\begin{array}{c}0.00 \\
(0.00) \\
\end{array}$ & & & & $\begin{array}{c}0.10 \\
(2.86) \\
\end{array}$ & $4.77 \%$ \\
\hline \multicolumn{13}{|c|}{ PANEL 7. UNITED STATES } \\
\hline & Intercept & $\sigma_{t}^{2}$ & $\Delta \sigma_{t}^{2}$ & $\mu_{\mathrm{t}-1}$ & $\varepsilon_{\sigma t}^{2}$ & Adj. $R^{2}$ & Intercept & $\sigma_{t}^{2}$ & $\Delta \sigma_{t}^{2}$ & $\mu_{t-1}$ & $\varepsilon_{\sigma}^{2}$ & Adj. $R^{2}$ \\
\hline$\mu_{\mathrm{t}}$ & $\begin{array}{c}0.04 \\
(15.33)\end{array}$ & $\begin{array}{c}0.15 \\
(1.83)\end{array}$ & & & & $7.31 \%$ & $\begin{array}{c}0.03 \\
(13.92)\end{array}$ & $\begin{array}{c}0.07 \\
(1.20)\end{array}$ & & & & $3.39 \%$ \\
\hline$\mu_{\mathrm{t}}$ & $\begin{array}{c}0.00 \\
(2.84)\end{array}$ & $\begin{array}{c}0.09 \\
(11.53)\end{array}$ & & $\begin{array}{c}0.90 \\
(35.11)\end{array}$ & & $85.93 \%$ & $\begin{array}{c}0.00 \\
(2.87)\end{array}$ & $\begin{array}{c}0.06 \\
(7.57)\end{array}$ & & $\begin{array}{c}0.84 \\
(20.45)\end{array}$ & & $72.45 \%$ \\
\hline$\mu_{\mathrm{t}}$ & $\begin{array}{c}0.00 \\
(2.75)\end{array}$ & & $\begin{array}{c}0.05 \\
(2.43)\end{array}$ & $\begin{array}{c}0.93 \\
(36.43)\end{array}$ & & $84.69 \%$ & $\begin{array}{c}0.00 \\
(3.21)\end{array}$ & & $\begin{array}{c}0.03 \\
(1.83)\end{array}$ & $\begin{array}{c}0.86 \\
(19.63)\end{array}$ & & $70.84 \%$ \\
\hline$\Delta \mu_{\mathrm{t}}$ & $\begin{array}{c}0.00 \\
(0.20)\end{array}$ & & $\begin{array}{c}0.06 \\
(2.61)\end{array}$ & & & $9.17 \%$ & $\begin{array}{c}0.00 \\
(0.45)\end{array}$ & & $\begin{array}{c}0.04 \\
(1.96)\end{array}$ & & & $3.76 \%$ \\
\hline$\varepsilon_{\mu \mathrm{t}}$ & $\begin{array}{c}0.00 \\
(0.00)\end{array}$ & & & & $\begin{array}{c}0.09 \\
(11.76)\end{array}$ & $15.58 \%$ & $\begin{array}{c}0.00 \\
(0.00)\end{array}$ & & & & $\begin{array}{c}0.06 \\
(7.70)\end{array}$ & $7.64 \%$ \\
\hline
\end{tabular}


Table 11

Country Risk Premia, World Market Volatility, and Conditional Covariance with the World Market

The table contains the results of time-series regressions using monthly data over the period July 1990 to December 2002. $\mu_{\mathrm{t}}$ is the individual country implied risk premium. $\sigma_{\mathrm{t}}$ is the "world volatility', computed as the square root of 252 times the standard deviation of the daily returns on the market, computed over the previous month, where the 'market' is the MSCI World ( covariance is multiplied by 252 for annualization. $\varepsilon_{\mu t}\left(\varepsilon_{\sigma t}, \varepsilon_{c o v t}\right)$ is the residual from an AR (1) model for the implied premium (standard deviation, covariance). Data for the United States computed using the Newey-West correction with 12 lags of autocorrelation in the first specification and 1 lag of autocorrelation in other specifications and also corrected for

\begin{tabular}{|c|c|c|c|c|c|c|c|c|c|c|c|c|c|c|c|c|c|c|}
\hline \multicolumn{19}{|c|}{ PANEL 1. CANADA } \\
\hline & \multicolumn{8}{|c|}{ Equal-Weighted Risk Premia } & \multicolumn{10}{|c|}{ Value-Weighted Risk Premia } \\
\hline & Intercept & $\sigma_{t}^{2}$ & $\Delta \sigma_{t}^{2}$ & $\operatorname{cov}_{t}$ & $\Delta \operatorname{cov}_{t}$ & $\mu_{t-1}$ & $\varepsilon_{\sigma t}^{2}$ & $\varepsilon_{\text {covt }}$ & Adj. $\mathrm{R}^{2}$ & Intercept & $\sigma_{t}^{2}$ & $\Delta \sigma_{t}^{2}$ & $\operatorname{cov}_{t}$ & $\Delta \operatorname{cov}_{t}$ & $\mu_{t-1}$ & $\varepsilon_{\sigma t}^{2}$ & $\varepsilon_{\text {covt }}$ & Adj. $\mathbf{R}^{2}$ \\
\hline$\mu_{\mathrm{t}}$ & $\begin{array}{c}0.08 \\
(12.79)\end{array}$ & $\begin{array}{c}-0.60 \\
(-2.01)\end{array}$ & & $\begin{array}{l}1.20 \\
(2.96)\end{array}$ & & & & & $20.32 \%$ & $\begin{array}{c}0.05 \\
(11.61)\end{array}$ & $\begin{array}{c}-0.38 \\
(-1.29)\end{array}$ & & $\begin{array}{c}0.54 \\
(1.50)\end{array}$ & & & & & $7.29 \%$ \\
\hline$\mu_{\mathrm{t}}$ & $\begin{array}{c}0.00 \\
(2.69)\end{array}$ & $\begin{array}{c}0.01 \\
(0.14)\end{array}$ & & $\begin{array}{c}0.07 \\
(1.08)\end{array}$ & & $\begin{array}{c}0.93 \\
(38.85)\end{array}$ & & & $92.56 \%$ & $\begin{array}{c}0.01 \\
(3.02)\end{array}$ & $\begin{array}{c}-0.04 \\
(-0.81)\end{array}$ & & $\begin{array}{c}0.06 \\
(1.11)\end{array}$ & & $\begin{array}{c}0.87 \\
(21.84)\end{array}$ & & & $77.57 \%$ \\
\hline$\mu_{\mathrm{t}}$ & $\begin{array}{c}0.00 \\
(2.73)\end{array}$ & & $\begin{array}{c}-0.07 \\
(-1.03)\end{array}$ & & $\begin{array}{c}0.14 \\
(1.69)\end{array}$ & $\begin{array}{c}0.95 \\
(47.56)\end{array}$ & & & $92.56 \%$ & $\begin{array}{c}0.01 \\
(2.91)\end{array}$ & & $\begin{array}{c}-0.08 \\
(-1.64)\end{array}$ & & $\begin{array}{c}0.12 \\
(2.03)\end{array}$ & $\begin{array}{c}0.88 \\
(22.90)\end{array}$ & & & $77.84 \%$ \\
\hline$\Delta \mu_{\mathrm{t}}$ & $\begin{array}{c}0.00 \\
(0.94)\end{array}$ & & $\begin{array}{c}-0.07 \\
(-1.00)\end{array}$ & & $\begin{array}{c}0.14 \\
(1.67)\end{array}$ & & & & $1.58 \%$ & $\begin{array}{c}0.00 \\
(0.24)\end{array}$ & & $\begin{array}{c}-0.08 \\
(-1.64)\end{array}$ & & $\begin{array}{c}0.12 \\
(1.95)\end{array}$ & & & & $0.31 \%$ \\
\hline$\varepsilon_{\mu \mathrm{t}}$ & $\begin{array}{c}0.00 \\
(0.00) \\
\end{array}$ & & & & & & $\begin{array}{c}-0.03 \\
(-0.55) \\
\end{array}$ & $\begin{array}{r}0.12 \\
(1.58) \\
\end{array}$ & $1.75 \%$ & $\begin{array}{c}0.00 \\
(0.00) \\
\end{array}$ & & & & & & $\begin{array}{c}-0.08 \\
(-1.62) \\
\end{array}$ & $\begin{array}{c}0.12 \\
(1.95) \\
\end{array}$ & $0.04 \%$ \\
\hline \multicolumn{19}{|c|}{ PANEL 2. FRANCE } \\
\hline & & & Equal-W & eighted & Risk Pr & remia & & & & & & alue-W & ighted & Risk Pr & remia & & & \\
\hline & Intercept & $\sigma_{t}^{2}$ & $\Delta \sigma_{t}^{2}$ & $\operatorname{cov}_{t}$ & $\Delta \operatorname{cov}_{\mathrm{t}}$ & $\mu_{t-1}$ & $\varepsilon_{\sigma t}^{2}$ & $\varepsilon_{\text {covt }}$ & Adj. $R^{2}$ & Intercept & $\sigma_{t}^{2}$ & $\Delta \sigma_{t}{ }^{2}$ & $\operatorname{cov}_{t}$ & $\Delta \operatorname{cov}_{t}$ & $\mu_{t-1}$ & $\varepsilon_{\sigma t}^{2}$ & $\varepsilon_{\text {covt }}$ & Adj. $R^{2}$ \\
\hline$\mu_{\mathrm{t}}$ & $\begin{array}{c}0.05 \\
(13.84)\end{array}$ & $\begin{array}{c}-0.95 \\
(-2.12)\end{array}$ & & $\begin{array}{c}1.16 \\
(3.39)\end{array}$ & & & & & $23.34 \%$ & $\begin{array}{c}0.03 \\
(20.31)\end{array}$ & $\begin{array}{c}-0.41 \\
(-2.59)\end{array}$ & & $\begin{array}{c}0.53 \\
(4.14)\end{array}$ & & & & & $29.34 \%$ \\
\hline$\mu_{\mathrm{t}}$ & $\begin{array}{c}0.00 \\
(2.10)\end{array}$ & $\begin{array}{c}-0.04 \\
(-0.45)\end{array}$ & & $\begin{array}{c}0.11 \\
(1.51)\end{array}$ & & $\begin{array}{c}0.92 \\
(32.82)\end{array}$ & & & $92.08 \%$ & $\begin{array}{c}0.01 \\
(2.68)\end{array}$ & $\begin{array}{c}-0.12 \\
(-1.54)\end{array}$ & & $\begin{array}{c}0.16 \\
(2.37)\end{array}$ & & $\begin{array}{c}0.71 \\
(7.00)\end{array}$ & & & $71.14 \%$ \\
\hline$\mu_{\mathrm{t}}$ & $\begin{array}{c}0.00 \\
(2.12)\end{array}$ & & $\begin{array}{c}-0.02 \\
(-0.28)\end{array}$ & & $\begin{array}{c}0.10 \\
(1.67)\end{array}$ & $\begin{array}{c}0.96 \\
(40.73)\end{array}$ & & & $92.17 \%$ & $\begin{array}{c}0.01 \\
(2.22)\end{array}$ & & $\begin{array}{c}-0.04 \\
(-0.76)\end{array}$ & & $\begin{array}{c}0.07 \\
(1.26)\end{array}$ & $\begin{array}{c}0.80 \\
(8.78)\end{array}$ & & & $69.19 \%$ \\
\hline$\Delta \mu_{\mathrm{t}}$ & $\begin{array}{c}0.00 \\
(0.91)\end{array}$ & & $\begin{array}{c}-0.02 \\
(-0.26)\end{array}$ & & $\begin{array}{c}0.10 \\
(1.69)\end{array}$ & & & & $6.31 \%$ & $\begin{array}{c}0.00 \\
(1.03)\end{array}$ & & $\begin{array}{c}-0.04 \\
(-0.70)\end{array}$ & & $\begin{array}{c}0.07 \\
(1.45)\end{array}$ & & & & $0.60 \%$ \\
\hline$\varepsilon_{\mu \mathrm{t}}$ & $\begin{array}{c}0.00 \\
(0.00) \\
\end{array}$ & & & & & & $\begin{array}{c}-0.03 \\
(-0.41)\end{array}$ & $\begin{array}{c}0.13 \\
(1.98)\end{array}$ & $7.60 \%$ & $\begin{array}{c}0.00 \\
(0.00)\end{array}$ & & & & & & $\begin{array}{c}-0.05 \\
(-0.73) \\
\end{array}$ & $\begin{array}{c}0.10 \\
(1.61)\end{array}$ & $3.03 \%$ \\
\hline \multicolumn{19}{|c|}{ PANEL 3. GERMANY } \\
\hline & & & Equal-W & eighted & Risk Pr & remia & & & & & & Value-W & ighted & Risk Pr & remia & & & \\
\hline & Intercept & $\sigma_{t}^{2}$ & $\Delta \sigma_{t}^{2}$ & $\operatorname{cov}_{t}$ & $\Delta \operatorname{cov}_{t}$ & $\mu_{\mathrm{t}-1}$ & $\varepsilon_{\sigma t}^{2}$ & $\varepsilon_{\text {covt }}$ & Adj. $R^{2}$ & Intercept & $\sigma_{t}^{2}$ & $\Delta \sigma_{t}^{2}$ & $\operatorname{cov}_{t}$ & $\Delta \operatorname{cov}_{t}$ & $\mu_{t-1}$ & $\varepsilon_{\sigma t}^{2}$ & $\varepsilon_{\text {covt }}$ & Adj. $R^{2}$ \\
\hline$\mu_{\mathrm{t}}$ & $\begin{array}{c}0.04 \\
(4.83)\end{array}$ & $\begin{array}{c}-1.70 \\
(-2.79)\end{array}$ & & $\begin{array}{c}1.98 \\
(5.64)\end{array}$ & & & & & $29.69 \%$ & $\begin{array}{c}0.01 \\
(4.72)\end{array}$ & $\begin{array}{c}-1.02 \\
(-3.40)\end{array}$ & & $\begin{array}{c}1.04 \\
(5.57)\end{array}$ & & & & & $37.55 \%$ \\
\hline$\mu_{\mathrm{t}}$ & $\begin{array}{c}0.00 \\
(0.58)\end{array}$ & $\begin{array}{c}0.00 \\
(-0.04)\end{array}$ & & $\begin{array}{c}0.03 \\
(0.42)\end{array}$ & & $\begin{array}{c}0.99 \\
(43.46)\end{array}$ & & & $96.91 \%$ & $\begin{array}{c}0.00 \\
(2.24)\end{array}$ & $\begin{array}{c}-0.25 \\
(-1.78)\end{array}$ & & $\begin{array}{c}0.23 \\
(2.49)\end{array}$ & & $\begin{array}{c}0.85 \\
(16.71)\end{array}$ & & & $83.40 \%$ \\
\hline$\mu_{\mathrm{t}}$ & $\begin{array}{c}0.00 \\
(0.99)\end{array}$ & & $\begin{array}{c}-0.03 \\
(-0.32)\end{array}$ & & $\begin{array}{c}0.06 \\
(1.15)\end{array}$ & $\begin{array}{c}1.00 \\
(51.37)\end{array}$ & & & $96.94 \%$ & $\begin{array}{c}0.00 \\
(1.73)\end{array}$ & & $\begin{array}{c}-0.17 \\
(-1.28)\end{array}$ & & $\begin{array}{c}0.14 \\
(1.51)\end{array}$ & $\begin{array}{c}0.92 \\
(20.43)\end{array}$ & & & $82.79 \%$ \\
\hline$\Delta \mu_{\mathrm{t}}$ & $\begin{array}{c}0.00 \\
(1.34)\end{array}$ & & $\begin{array}{c}-0.03 \\
(-0.32)\end{array}$ & & $\begin{array}{c}0.06 \\
(1.15)\end{array}$ & & & & $0.49 \%$ & $\begin{array}{c}0.00 \\
(0.78)\end{array}$ & & $\begin{array}{c}-0.17 \\
(-1.28)\end{array}$ & & $\begin{array}{c}0.14 \\
(1.50)\end{array}$ & & & & $1.05 \%$ \\
\hline$\varepsilon_{\mu \mathrm{t}}$ & $\begin{array}{c}0.00 \\
(0.00)\end{array}$ & & & & & & $\begin{array}{c}-0.04 \\
(-0.38) \\
\end{array}$ & $\begin{array}{c}0.08 \\
(1.25)\end{array}$ & $0.38 \%$ & $\begin{array}{c}0.00 \\
(0.00)\end{array}$ & & & & & & $\begin{array}{c}-0.18 \\
(-1.24) \\
\end{array}$ & $\begin{array}{c}0.17 \\
(1.74)\end{array}$ & $1.65 \%$ \\
\hline \multicolumn{19}{|c|}{ PANEL 4. ITALY } \\
\hline & & & Equal-W & eighted & Risk Pr & remia & & & & & & Value-W & ighted & Risk Pr & remia & & & \\
\hline & Intercept & $\sigma_{t}^{2}$ & $\Delta \sigma_{t}^{2}$ & $\operatorname{cov}_{t}$ & $\Delta \operatorname{cov}_{\mathrm{t}}$ & $\mu_{t-1}$ & $\varepsilon_{\sigma t}^{2}$ & $\varepsilon_{\text {covt }}$ & Adj. $R^{2}$ & Intercept & $\sigma_{t}^{2}$ & $\Delta \sigma_{t}^{2}$ & $\operatorname{cov}_{t}$ & $\Delta \operatorname{cov}_{\mathrm{t}}$ & $\mu_{t-1}$ & $\varepsilon_{\sigma t}^{2}$ & $\varepsilon_{\text {covt }}$ & Adj. $R^{2}$ \\
\hline$\mu_{\mathrm{t}}$ & $\begin{array}{c}0.03 \\
(3.82)\end{array}$ & $\begin{array}{c}-0.69 \\
(-1.04)\end{array}$ & & $\begin{array}{l}1.42 \\
(2.59)\end{array}$ & & & & & $16.77 \%$ & $\begin{array}{c}0.00 \\
(0.03)\end{array}$ & $\begin{array}{c}-0.72 \\
(-1.26)\end{array}$ & & $\begin{array}{c}1.27 \\
(2.78)\end{array}$ & & & & & $16.44 \%$ \\
\hline$\mu_{\mathrm{t}}$ & $\begin{array}{c}0.00 \\
(1.14)\end{array}$ & $\begin{array}{c}0.00 \\
(0.01)\end{array}$ & & $\begin{array}{c}0.02 \\
(0.19)\end{array}$ & & $\begin{array}{c}0.96 \\
(34.75)\end{array}$ & & & $93.07 \%$ & $\begin{array}{c}0.00 \\
(0.83)\end{array}$ & $\begin{array}{c}-0.02 \\
(-0.16)\end{array}$ & & $\begin{array}{c}0.04 \\
(0.38)\end{array}$ & & $\begin{array}{c}0.95 \\
(34.23)\end{array}$ & & & $93.23 \%$ \\
\hline$\mu_{\mathrm{t}}$ & $\begin{array}{c}0.00 \\
(1.41)\end{array}$ & & $\begin{array}{c}-0.02 \\
(-0.17)\end{array}$ & & $\begin{array}{c}0.00 \\
(0.02)\end{array}$ & $\begin{array}{c}0.97 \\
(38.83)\end{array}$ & & & $93.06 \%$ & $\begin{array}{c}0.00 \\
(1.39)\end{array}$ & & $\begin{array}{c}-0.05 \\
(-0.57)\end{array}$ & & $\begin{array}{c}0.04 \\
(0.50)\end{array}$ & $\begin{array}{c}0.96 \\
(39.50)\end{array}$ & & & $93.23 \%$ \\
\hline$\Delta \mu_{\mathrm{t}}$ & $\begin{array}{c}0.00 \\
(1.07)\end{array}$ & & $\begin{array}{c}-0.02 \\
(-0.16)\end{array}$ & & $\begin{array}{c}0.00 \\
(0.01)\end{array}$ & & & & $-1.31 \%$ & $\begin{array}{c}0.00 \\
(1.17)\end{array}$ & & $\begin{array}{c}-0.05 \\
(-0.56)\end{array}$ & & $\begin{array}{c}0.04 \\
(0.47)\end{array}$ & & & & $-1.13 \%$ \\
\hline$\varepsilon_{\mu \mathrm{t}}$ & $\begin{array}{c}0.00 \\
(-0.00)\end{array}$ & & & & & & $\begin{array}{c}0.00 \\
(-0.01) \\
\end{array}$ & $\begin{array}{c}0.01 \\
(0.05)\end{array}$ & $-1.36 \%$ & $\begin{array}{c}0.00 \\
(-0.01) \\
\end{array}$ & & & & & & $\begin{array}{c}-0.04 \\
(-0.31)\end{array}$ & $\begin{array}{c}0.05 \\
(0.41)\end{array}$ & $-1.19 \%$ \\
\hline
\end{tabular}




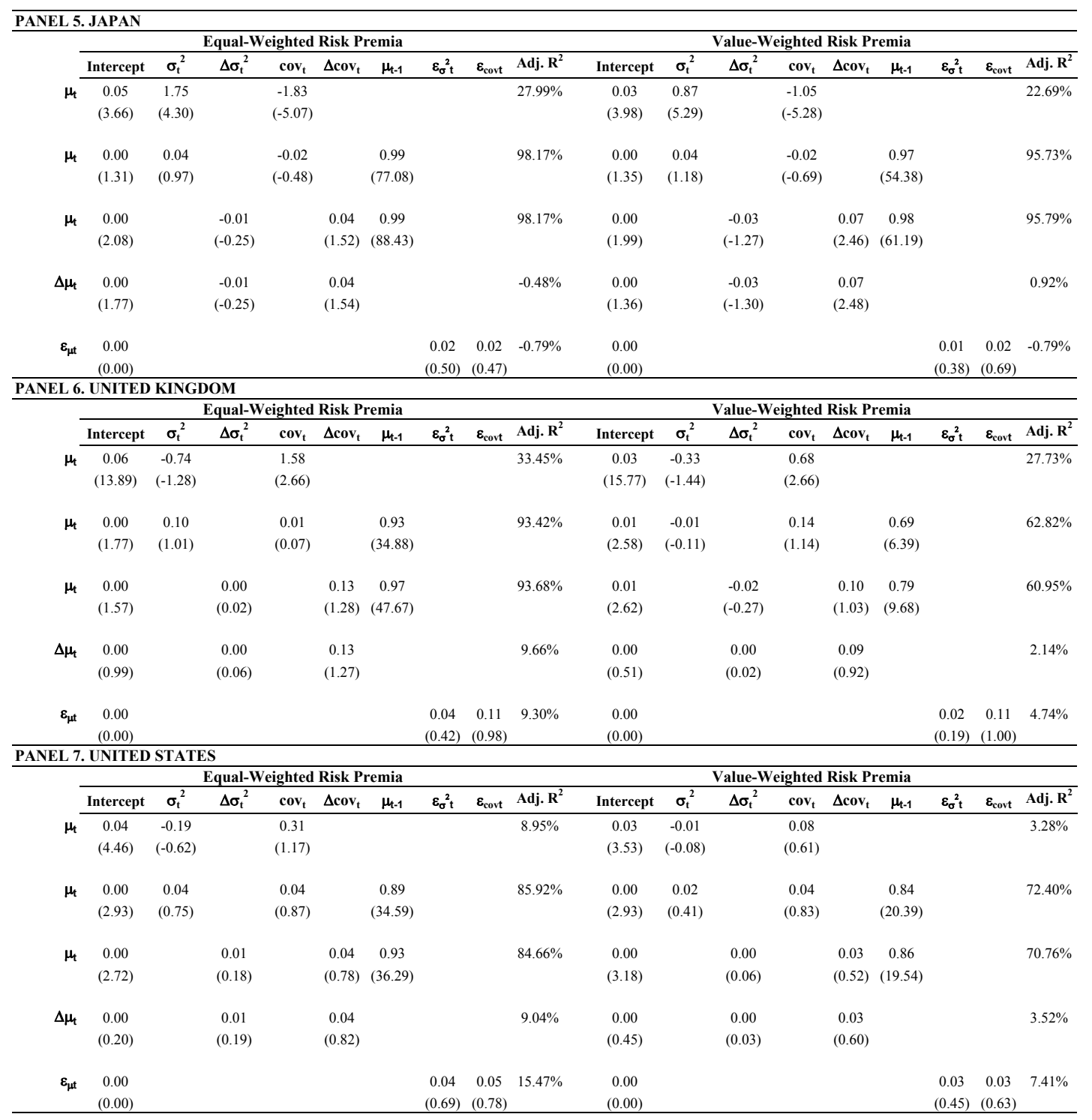


Table 12

Volatility and Equal-Weighted Dividend Yields

The table contains the results of time-series (monthly) regressions. The regressions are run over the period 1981-2002 for the United States and over 1990-2002 for the other countries (For Italy, the time series of risk premia starts in July 1990). $\mu_{\text {in }}$ is the equal-weighted average of the dividend yield premia, defined as the difference between the dividend yield and the yield on the local long-term government bond. Firm-level dividend yield is computed as the ratio of total dividends from the most recent fiscal year ending at least six months (three months in case of US) prior, to the market capitalization at the end of the month. $\sigma_{t}$ is square root of 252 times the standard deviation of the daily returns on the market, computed over the last one month, where the 'market' is defined as the CRSP value-weighted index for the United States and the MSCI index for other countries. $\varepsilon_{\text {tit }}\left(\varepsilon_{\sigma t}\right)$ is the residual from an AR (1) model for expected returns (standard deviation). Data for the United States is obtained from COMPUSTAT, CRSP and IBES. Data on other countries is obtained from Worldscope, Datastream and IBES. The numbers in parentheses are t-statistics computed using Newey-West correction with 12 lags of autocorrelation in the first specification and 1 lag of autocorrelation in the other specifications and also corrected for heteroskedasticity.

\begin{tabular}{|c|c|c|c|c|c|c|c|c|c|c|c|c|c|}
\hline \multicolumn{14}{|c|}{ PANEL 1. CANADA } \\
\hline & Intercept & $\sigma_{t}^{2}$ & $\Delta \sigma_{t}^{2}$ & $\mu_{\mathrm{t}-1}$ & $\varepsilon_{\sigma}^{2}$ & Adj. $\mathrm{R}^{2}$ & & Intercept & $\sigma_{\mathrm{t}}$ & $\Delta \sigma_{\mathrm{t}}$ & $\mu_{\mathrm{t}-1}$ & $\varepsilon_{\sigma t}$ & Adj. $\mathrm{R}^{2}$ \\
\hline$\mu_{\mathrm{t}}$ & $\begin{array}{c}-0.05 \\
(-16.58)\end{array}$ & $\begin{array}{c}0.20 \\
(4.28)\end{array}$ & & & & $22.65 \%$ & $\mu_{\mathrm{t}}$ & $\begin{array}{c}-0.06 \\
(-14.64)\end{array}$ & $\begin{array}{c}0.09 \\
(4.94)\end{array}$ & & & & $30.90 \%$ \\
\hline$\mu_{\mathrm{t}}$ & $\begin{array}{c}0.00 \\
(-2.07)\end{array}$ & $\begin{array}{c}0.02 \\
(1.83)\end{array}$ & & $\begin{array}{c}0.92 \\
(25.95)\end{array}$ & & $88.66 \%$ & $\mu_{\mathrm{t}}$ & $\begin{array}{c}-0.01 \\
(-2.11)\end{array}$ & $\begin{array}{c}0.01 \\
(1.86)\end{array}$ & & $\begin{array}{c}0.91 \\
(23.51)\end{array}$ & & $88.71 \%$ \\
\hline$\mu_{\mathrm{t}}$ & $\begin{array}{c}0.00 \\
(-1.61)\end{array}$ & & $\begin{array}{c}0.01 \\
(0.95)\end{array}$ & $\begin{array}{c}0.95 \\
(31.32)\end{array}$ & & $88.52 \%$ & $\mu_{\mathrm{t}}$ & $\begin{array}{c}0.00 \\
(-1.61)\end{array}$ & & $\begin{array}{c}0.01 \\
(1.05)\end{array}$ & $\begin{array}{c}0.95 \\
(31.31)\end{array}$ & & $88.52 \%$ \\
\hline$\Delta \mu_{\mathrm{t}}$ & $\begin{array}{c}0.00 \\
(0.76)\end{array}$ & & $\begin{array}{c}0.01 \\
(0.98)\end{array}$ & & & $-0.26 \%$ & $\Delta \mu_{\mathrm{t}}$ & $\begin{array}{c}0.00 \\
(0.75)\end{array}$ & & $\begin{array}{c}0.01 \\
(1.09)\end{array}$ & & & $-0.23 \%$ \\
\hline$\varepsilon_{\mu \mathrm{t}}$ & $\begin{array}{c}0.00 \\
(0.00) \\
\end{array}$ & & & & $\begin{array}{c}0.02 \\
(1.60) \\
\end{array}$ & $0.20 \%$ & $\varepsilon_{\mu \mathrm{t}}$ & $\begin{array}{c}0.00 \\
(0.00) \\
\end{array}$ & & & & $\begin{array}{c}0.01 \\
(1.65) \\
\end{array}$ & $0.23 \%$ \\
\hline \multicolumn{14}{|c|}{ PANEL 2. FRANCE } \\
\hline & Intercept & $\sigma_{t}^{2}$ & $\Delta \sigma_{t}^{2}$ & $\mu_{\mathrm{t}-1}$ & $\varepsilon_{\sigma t}^{2}$ & Adj. $\mathrm{R}^{2}$ & & Intercept & $\sigma_{\mathrm{t}}$ & $\Delta \sigma_{\mathrm{t}}$ & $\mu_{\mathrm{t}-1}$ & $\varepsilon_{\sigma t}$ & Adj. $\mathrm{R}^{2}$ \\
\hline$\mu_{\mathrm{t}}$ & $\begin{array}{c}-0.05 \\
(-11.60)\end{array}$ & $\begin{array}{c}0.15 \\
(6.62)\end{array}$ & & & & $15.09 \%$ & $\mu_{\mathrm{t}}$ & $\begin{array}{c}-0.06 \\
(-12.13)\end{array}$ & $\begin{array}{c}0.09 \\
(5.83)\end{array}$ & & & & $16.99 \%$ \\
\hline$\mu_{\mathrm{t}}$ & $\begin{array}{c}-0.01 \\
(-1.84)\end{array}$ & $\begin{array}{c}0.04 \\
(2.65)\end{array}$ & & $\begin{array}{c}0.85 \\
(9.80)\end{array}$ & & $79.11 \%$ & $\mu_{\mathrm{t}}$ & $\begin{array}{c}-0.01 \\
(-1.96)\end{array}$ & $\begin{array}{c}0.03 \\
(2.34)\end{array}$ & & $\begin{array}{c}0.84 \\
(9.38)\end{array}$ & & $79.34 \%$ \\
\hline$\mu_{\mathrm{t}}$ & $\begin{array}{c}0.00 \\
(-1.29)\end{array}$ & & $\begin{array}{c}0.02 \\
(2.19)\end{array}$ & $\begin{array}{c}0.89 \\
(11.59)\end{array}$ & & $78.16 \%$ & $\mu_{\mathrm{t}}$ & $\begin{array}{c}0.00 \\
(-1.30)\end{array}$ & & $\begin{array}{c}0.02 \\
(1.91)\end{array}$ & $\begin{array}{c}0.89 \\
(11.98)\end{array}$ & & $78.32 \%$ \\
\hline$\Delta \mu_{\mathrm{t}}$ & $\begin{array}{c}0.00 \\
(0.70)\end{array}$ & & $\begin{array}{c}0.03 \\
(2.35)\end{array}$ & & & $0.75 \%$ & $\Delta \mu_{\mathrm{t}}$ & $\begin{array}{c}0.00 \\
(0.68)\end{array}$ & & $\begin{array}{c}0.02 \\
(1.82)\end{array}$ & & & $1.63 \%$ \\
\hline$\varepsilon_{\mu \mathrm{t}}$ & $\begin{array}{c}0.00 \\
(0.00) \\
\end{array}$ & & & & $\begin{array}{r}0.04 \\
(3.54) \\
\end{array}$ & $2.25 \%$ & $\varepsilon_{\mu \mathrm{t}}$ & $\begin{array}{c}0.00 \\
(0.00) \\
\end{array}$ & & & & $\begin{array}{c}0.03 \\
(2.58) \\
\end{array}$ & $3.47 \%$ \\
\hline \multicolumn{14}{|c|}{ PANEL 3. GERMANY } \\
\hline & Intercept & $\sigma_{t}^{2}$ & $\Delta \sigma_{t}^{2}$ & $\mu_{\mathrm{t}-1}$ & $\varepsilon_{\sigma t}^{2}$ & Adj. $\mathrm{R}^{2}$ & & Intercept & $\sigma_{\mathrm{t}}$ & $\Delta \sigma_{\mathrm{t}}$ & $\mu_{\mathrm{t}-1}$ & $\varepsilon_{\sigma t}$ & Adj. $\mathrm{R}^{2}$ \\
\hline$\mu_{\mathrm{t}}$ & $\begin{array}{c}-0.04 \\
(-7.75)\end{array}$ & $\begin{array}{c}0.12 \\
(4.90)\end{array}$ & & & & $12.72 \%$ & $\mu_{\mathrm{t}}$ & $\begin{array}{c}-0.04 \\
(-9.84)\end{array}$ & $\begin{array}{c}0.07 \\
(3.88)\end{array}$ & & & & $14.61 \%$ \\
\hline$\mu_{\mathrm{t}}$ & $\begin{array}{c}0.00 \\
(-2.13)\end{array}$ & $\begin{array}{c}0.02 \\
(2.50)\end{array}$ & & $\begin{array}{c}0.96 \\
(43.79)\end{array}$ & & $94.54 \%$ & $\mu_{\mathrm{t}}$ & $\begin{array}{c}0.00 \\
(-2.21)\end{array}$ & $\begin{array}{c}0.01 \\
(2.04)\end{array}$ & & $\begin{array}{c}0.96 \\
(43.00)\end{array}$ & & $94.42 \%$ \\
\hline$\mu_{\mathrm{t}}$ & $\begin{array}{c}0.00 \\
(-0.48)\end{array}$ & & $\begin{array}{c}0.02 \\
(1.43)\end{array}$ & $\begin{array}{c}0.98 \\
(47.36)\end{array}$ & & $94.37 \%$ & $\mu_{\mathrm{t}}$ & $\begin{array}{c}0.00 \\
(-0.51)\end{array}$ & & $\begin{array}{c}0.01 \\
(1.17)\end{array}$ & $\begin{array}{c}0.98 \\
(46.75)\end{array}$ & & $94.30 \%$ \\
\hline$\Delta \mu_{\mathrm{t}}$ & $\begin{array}{c}0.00 \\
(1.02)\end{array}$ & & $\begin{array}{c}0.02 \\
(1.46)\end{array}$ & & & $2.23 \%$ & $\Delta \mu_{\mathrm{t}}$ & $\begin{array}{c}0.00 \\
(1.02)\end{array}$ & & $\begin{array}{c}0.01 \\
(1.19)\end{array}$ & & & $0.98 \%$ \\
\hline$\varepsilon_{\mu \mathrm{t}}$ & $\begin{array}{c}0.00 \\
(0.00) \\
\end{array}$ & & & & $\begin{array}{c}0.02 \\
(1.96) \\
\end{array}$ & $4.33 \%$ & $\varepsilon_{\mu \mathrm{t}}$ & $\begin{array}{c}0.00 \\
(0.00) \\
\end{array}$ & & & & $\begin{array}{c}0.01 \\
(1.53) \\
\end{array}$ & $2.24 \%$ \\
\hline \multicolumn{14}{|c|}{ PANEL 4. ITALY } \\
\hline & Intercept & $\sigma_{t}^{2}$ & $\Delta \sigma_{t}^{2}$ & $\mu_{\mathrm{t}-1}$ & $\varepsilon_{\sigma t}^{2}$ & Adj. $\mathrm{R}^{2}$ & & Intercept & $\sigma_{\mathrm{t}}$ & $\Delta \sigma_{\mathrm{t}}$ & $\mu_{\mathrm{t}-1}$ & $\varepsilon_{\sigma t}$ & Adj. $\mathrm{R}^{2}$ \\
\hline$\mu_{\mathrm{t}}$ & $\begin{array}{c}-0.08 \\
(-4.09)\end{array}$ & $\begin{array}{c}0.77 \\
(1.32)\end{array}$ & & & & $7.34 \%$ & $\mu_{\mathrm{t}}$ & $\begin{array}{c}-0.13 \\
(-2.49)\end{array}$ & $\begin{array}{c}0.42 \\
(1.34)\end{array}$ & & & & $7.78 \%$ \\
\hline$\mu_{\mathrm{t}}$ & $\begin{array}{c}0.00 \\
(-0.80)\end{array}$ & $\begin{array}{c}0.04 \\
(0.92)\end{array}$ & & $\begin{array}{c}0.86 \\
(13.48)\end{array}$ & & $69.04 \%$ & $\mu_{\mathrm{t}}$ & $\begin{array}{c}-0.01 \\
(-1.24)\end{array}$ & $\begin{array}{c}0.03 \\
(1.16)\end{array}$ & & $\begin{array}{c}0.86 \\
(13.25)\end{array}$ & & $69.06 \%$ \\
\hline$\mu_{\mathrm{t}}$ & $\begin{array}{c}0.00 \\
(-0.51)\end{array}$ & & $\begin{array}{c}0.01 \\
(0.24)\end{array}$ & $\begin{array}{c}0.86 \\
(13.57)\end{array}$ & & $69.03 \%$ & $\mu_{\mathrm{t}}$ & $\begin{array}{c}0.00 \\
(-0.51)\end{array}$ & & $\begin{array}{c}0.02 \\
(0.37)\end{array}$ & $\begin{array}{c}0.86 \\
(13.46)\end{array}$ & & $69.04 \%$ \\
\hline$\Delta \mu_{\mathrm{t}}$ & $\begin{array}{c}0.00 \\
(0.70)\end{array}$ & & $\begin{array}{c}0.00 \\
(0.05)\end{array}$ & & & $-0.68 \%$ & $\Delta \mu_{\mathrm{t}}$ & $\begin{array}{c}0.00 \\
(0.70)\end{array}$ & & $\begin{array}{c}0.01 \\
(0.23)\end{array}$ & & & $-0.66 \%$ \\
\hline$\varepsilon_{\mu \mathrm{t}}$ & $\begin{array}{c}0.00 \\
(-0.01) \\
\end{array}$ & & & & $\begin{array}{c}0.03 \\
(0.51) \\
\end{array}$ & $-0.64 \%$ & $\varepsilon_{\mu \mathrm{t}}$ & $\begin{array}{c}0.00 \\
(-0.01)\end{array}$ & & & & $\begin{array}{c}0.03 \\
(0.66)\end{array}$ & $-0.59 \%$ \\
\hline
\end{tabular}




\begin{tabular}{|c|c|c|c|c|c|c|c|c|c|c|c|c|c|}
\hline \multicolumn{14}{|c|}{ PANEL 5. JAPAN } \\
\hline & Intercept & $\sigma_{t}^{2}$ & $\Delta \sigma_{t}^{2}$ & $\mu_{\mathrm{t}-1}$ & $\varepsilon_{\sigma t}^{2}$ & Adj. $\mathrm{R}^{2}$ & & Intercept & $\sigma_{\mathrm{t}}$ & $\Delta \sigma_{\mathrm{t}}$ & $\mu_{\mathrm{t}-1}$ & $\varepsilon_{\sigma t}$ & Adj. $R^{2}$ \\
\hline$\mu_{\mathrm{t}}$ & $\begin{array}{c}-0.02 \\
(-3.89)\end{array}$ & $\begin{array}{c}0.00 \\
(-0.04)\end{array}$ & & & & $-0.65 \%$ & $\mu_{\mathrm{t}}$ & $\begin{array}{c}-0.03 \\
(-4.26)\end{array}$ & $\begin{array}{c}0.02 \\
(0.58)\end{array}$ & & & & $-0.02 \%$ \\
\hline$\mu_{\mathrm{t}}$ & $\begin{array}{c}0.00 \\
(-0.63)\end{array}$ & $\begin{array}{c}0.01 \\
(1.68)\end{array}$ & & $\begin{array}{c}0.99 \\
(55.14)\end{array}$ & & $97.67 \%$ & $\mu_{\mathrm{t}}$ & $\begin{array}{c}0.00 \\
(-1.38)\end{array}$ & $\begin{array}{c}0.01 \\
(1.90)\end{array}$ & & $\begin{array}{c}0.99 \\
(54.85)\end{array}$ & & $97.68 \%$ \\
\hline$\mu_{\mathrm{t}}$ & $\begin{array}{c}0.00 \\
(0.19)\end{array}$ & & $\begin{array}{c}0.00 \\
(0.68)\end{array}$ & $\begin{array}{c}0.99 \\
(54.18)\end{array}$ & & $97.63 \%$ & $\mu_{\mathrm{t}}$ & $\begin{array}{c}0.00 \\
(0.19)\end{array}$ & & $\begin{array}{c}0.00 \\
(0.55)\end{array}$ & $\begin{array}{c}0.99 \\
(54.13)\end{array}$ & & $97.62 \%$ \\
\hline$\Delta \mu_{\mathrm{t}}$ & $\begin{array}{c}0.00 \\
(1.19)\end{array}$ & & $\begin{array}{c}0.00 \\
(0.72)\end{array}$ & & & $-0.45 \%$ & $\Delta \mu_{\mathrm{t}}$ & $\begin{array}{c}0.00 \\
(1.19)\end{array}$ & & $\begin{array}{c}0.00 \\
(0.60)\end{array}$ & & & $-0.49 \%$ \\
\hline$\varepsilon_{\mu \mathrm{t}}$ & $\begin{array}{c}0.00 \\
(0.00) \\
\end{array}$ & & & & $\begin{array}{c}0.01 \\
(1.47) \\
\end{array}$ & $0.73 \%$ & $\varepsilon_{\mu \mathrm{t}}$ & $\begin{array}{c}0.00 \\
(0.00) \\
\end{array}$ & & & & $\begin{array}{c}0.01 \\
(1.56) \\
\end{array}$ & $0.92 \%$ \\
\hline \multicolumn{14}{|c|}{ PANEL 6. UNITED KINGDOM } \\
\hline & Intercept & $\sigma_{t}^{2}$ & $\Delta \sigma_{\mathrm{t}}^{2}$ & $\mu_{\mathrm{t}-1}$ & $\varepsilon_{\sigma t}^{2}$ & Adj. $\mathbf{R}^{2}$ & & Intercept & $\sigma_{\mathrm{t}}$ & $\Delta \sigma_{\mathrm{t}}$ & $\mu_{\mathrm{t}-1}$ & $\varepsilon_{\sigma t}$ & $\operatorname{Adj} . R^{2}$ \\
\hline$\mu_{\mathrm{t}}$ & $\begin{array}{c}-0.08 \\
(-13.82)\end{array}$ & $\begin{array}{c}0.27 \\
(5.03)\end{array}$ & & & & $13.78 \%$ & $\mu_{\mathrm{t}}$ & $\begin{array}{c}-0.09 \\
(-15.68)\end{array}$ & $\begin{array}{c}0.13 \\
(6.74)\end{array}$ & & & & $17.08 \%$ \\
\hline$\mu_{\mathrm{t}}$ & $\begin{array}{c}0.00 \\
(-1.37)\end{array}$ & $\begin{array}{c}0.02 \\
(2.70)\end{array}$ & & $\begin{array}{c}0.98 \\
(67.21)\end{array}$ & & $97.96 \%$ & $\mu_{\mathrm{t}}$ & $\begin{array}{c}0.00 \\
(-1.57)\end{array}$ & $\begin{array}{c}0.01 \\
(2.08)\end{array}$ & & $\begin{array}{c}0.98 \\
(65.20)\end{array}$ & & $97.96 \%$ \\
\hline$\mu_{\mathrm{t}}$ & $\begin{array}{c}0.00 \\
(-0.51)\end{array}$ & & $\begin{array}{c}0.01 \\
(0.87)\end{array}$ & $\begin{array}{c}0.99 \\
(71.40)\end{array}$ & & $97.93 \%$ & $\mu_{\mathrm{t}}$ & $\begin{array}{c}0.00 \\
(-0.51)\end{array}$ & & $\begin{array}{c}0.00 \\
(0.66)\end{array}$ & $\begin{array}{c}0.99 \\
(71.44)\end{array}$ & & $97.93 \%$ \\
\hline$\Delta \mu_{\mathrm{t}}$ & $\begin{array}{c}0.00 \\
(1.56)\end{array}$ & & $\begin{array}{c}0.01 \\
(0.92)\end{array}$ & & & $-0.36 \%$ & $\Delta \mu_{\mathrm{t}}$ & $\begin{array}{c}0.00 \\
(1.56)\end{array}$ & & $\begin{array}{c}0.00 \\
(0.67)\end{array}$ & & & $-0.42 \%$ \\
\hline$\varepsilon_{\mu \mathrm{t}}$ & $\begin{array}{c}0.00 \\
(0.00) \\
\end{array}$ & & & & $\begin{array}{c}0.01 \\
(1.72) \\
\end{array}$ & $0.36 \%$ & $\varepsilon_{\mu \mathrm{t}}$ & $\begin{array}{c}0.00 \\
(0.00) \\
\end{array}$ & & & & $\begin{array}{c}0.01 \\
(1.26) \\
\end{array}$ & $0.14 \%$ \\
\hline \multicolumn{14}{|c|}{ PANEL 7. UNITED STATES } \\
\hline & Intercept & $\sigma_{t}^{2}$ & $\Delta \sigma_{t}^{2}$ & $\mu_{\mathrm{t}-1}$ & $\varepsilon_{\sigma t}^{2}$ & Adj. $R^{2}$ & & Intercept & $\sigma_{\mathrm{t}}$ & $\Delta \sigma_{\mathrm{t}}$ & $\mu_{\mathrm{t}-1}$ & $\varepsilon_{\sigma t}$ & Adj. $R^{2}$ \\
\hline$\mu_{\mathrm{t}}$ & $\begin{array}{c}-0.06 \\
(-14.09)\end{array}$ & $\begin{array}{c}0.08 \\
(1.09)\end{array}$ & & & & $2.22 \%$ & $\mu_{\mathrm{t}}$ & $\begin{array}{c}-0.07 \\
(-10.79)\end{array}$ & $\begin{array}{c}0.07 \\
(1.85)\end{array}$ & & & & $5.64 \%$ \\
\hline$\mu_{\mathrm{t}}$ & $\begin{array}{c}0.00 \\
(-1.77)\end{array}$ & $\begin{array}{c}0.02 \\
(6.80)\end{array}$ & & $\begin{array}{c}0.98 \\
(61.38)\end{array}$ & & $96.53 \%$ & $\mu_{\mathrm{t}}$ & $\begin{array}{c}0.00 \\
(-2.10)\end{array}$ & $\begin{array}{c}0.01 \\
(2.35)\end{array}$ & & $\begin{array}{c}0.98 \\
(59.29)\end{array}$ & & $96.45 \%$ \\
\hline$\mu_{\mathrm{t}}$ & $\begin{array}{c}0.00 \\
(-0.80)\end{array}$ & & $\begin{array}{c}0.01 \\
(2.41)\end{array}$ & $\begin{array}{c}0.98 \\
(60.38)\end{array}$ & & $96.43 \%$ & $\mu_{t}$ & $\begin{array}{c}0.00 \\
(-0.82)\end{array}$ & & $\begin{array}{c}0.01 \\
(1.62)\end{array}$ & $\begin{array}{c}0.98 \\
(60.15)\end{array}$ & & $96.40 \%$ \\
\hline$\Delta \mu_{\mathrm{t}}$ & $\begin{array}{c}0.00 \\
(0.99)\end{array}$ & & $\begin{array}{c}0.01 \\
(2.40)\end{array}$ & & & $1.86 \%$ & $\Delta \mu_{\mathrm{t}}$ & $\begin{array}{c}0.00 \\
(0.99)\end{array}$ & & $\begin{array}{c}0.01 \\
(1.62)\end{array}$ & & & $1.02 \%$ \\
\hline$\varepsilon_{\mu \mathrm{t}}$ & $\begin{array}{c}0.00 \\
(0.00) \\
\end{array}$ & & & & $\begin{array}{c}0.02 \\
(7.04) \\
\end{array}$ & $4.30 \%$ & $\varepsilon_{\mu \mathrm{t}}$ & $\begin{array}{c}0.00 \\
(0.00) \\
\end{array}$ & & & & $\begin{array}{c}0.01 \\
(2.36) \\
\end{array}$ & $2.23 \%$ \\
\hline
\end{tabular}




\section{Table 13}

Volatility and Value-Weighted Dividend Yields

The table contains the results of time-series (monthly) regressions. The regressions are run over the period 1981-2002 for the United States and over 1990-2002 for the other countries (For Italy, the time series of risk premia starts in July 1990). $\mu_{\mathrm{t}}$ is the value-weighted average of the dividend yield premia, defined as the difference between the

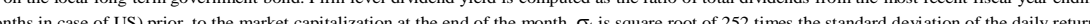
on the market, computed over the last one month, where the 'market' is defined as the CRSP value-weighted index for the United States and the MSCI index for other countries.

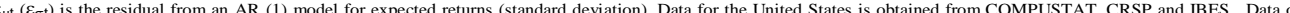
other countries is obtained from Worldscope, Datastream and IBES. The numbers in parentheses are t-statistics computed using Newey-West correction with 12 lags of autocorrelation in the first specification and 1 lag of autocorrelation in the other specifications and also corrected for heteroskedasticity.

\begin{tabular}{|c|c|c|c|c|c|c|c|c|c|c|c|c|c|}
\hline \multicolumn{14}{|c|}{ PANEL 1. CANADA } \\
\hline & Intercept & $\sigma_{t}{ }^{2}$ & $\Delta \sigma_{\mathrm{t}}^{2}$ & $\mu_{\mathrm{t}-1}$ & $\varepsilon_{\sigma}^{2}$ & Adj. $\mathbf{R}^{2}$ & & Intercept & $\sigma_{\mathrm{t}}$ & $\Delta \sigma_{\mathrm{t}}$ & $\mu_{\mathrm{t}-1}$ & $\varepsilon_{\sigma t}$ & Adj. $\mathbf{R}^{2}$ \\
\hline$\mu_{\mathrm{t}}$ & $\begin{array}{c}-0.05 \\
(-13.77)\end{array}$ & $\begin{array}{c}0.16 \\
(2.77)\end{array}$ & & & & $14.16 \%$ & $\mu_{\mathrm{t}}$ & $\begin{array}{c}-0.06 \\
(-11.15)\end{array}$ & $\begin{array}{c}0.08 \\
(3.14)\end{array}$ & & & & $20.59 \%$ \\
\hline$\mu_{\mathrm{t}}$ & $\begin{array}{c}0.00 \\
(-1.93)\end{array}$ & $\begin{array}{c}0.01 \\
(1.08)\end{array}$ & & $\begin{array}{c}0.94 \\
(34.36)\end{array}$ & & $90.61 \%$ & $\mu_{\mathrm{t}}$ & $\begin{array}{c}0.00 \\
(-1.72)\end{array}$ & $\begin{array}{c}0.00 \\
(0.90)\end{array}$ & & $\begin{array}{c}0.94 \\
(32.46)\end{array}$ & & $90.59 \%$ \\
\hline$\mu_{\mathrm{t}}$ & $\begin{array}{c}0.00 \\
(-1.75)\end{array}$ & & $\begin{array}{c}0.01 \\
(0.92)\end{array}$ & $\begin{array}{c}0.95 \\
(38.25)\end{array}$ & & $90.59 \%$ & $\mu_{\mathrm{t}}$ & $\begin{array}{c}0.00 \\
(-1.77)\end{array}$ & & $\begin{array}{c}0.01 \\
(1.13)\end{array}$ & $\begin{array}{c}0.95 \\
(38.43)\end{array}$ & & $90.60 \%$ \\
\hline$\Delta \mu_{\mathrm{t}}$ & $\begin{array}{c}0.00 \\
(0.96)\end{array}$ & & $\begin{array}{c}0.01 \\
(0.91)\end{array}$ & & & $-0.26 \%$ & $\Delta \mu_{\mathrm{t}}$ & $\begin{array}{c}0.00 \\
(0.96)\end{array}$ & & $\begin{array}{c}0.01 \\
(1.07)\end{array}$ & & & $-0.15 \%$ \\
\hline$\varepsilon_{\mu \mathrm{t}}$ & $\begin{array}{c}0.00 \\
(0.00)\end{array}$ & & & & $\begin{array}{c}0.01 \\
(1.07) \\
\end{array}$ & $-0.04 \%$ & $\varepsilon_{\mu \mathrm{t}}$ & $\begin{array}{c}0.00 \\
(0.00) \\
\end{array}$ & & & & $\begin{array}{c}0.01 \\
(1.19)\end{array}$ & $0.01 \%$ \\
\hline \multicolumn{14}{|c|}{ PANEL 2. FRANCE } \\
\hline & Intercept & $\sigma_{t}^{2}$ & $\Delta \sigma_{\mathrm{t}}^{2}$ & $\mu_{\mathrm{t}-1}$ & $\varepsilon_{\sigma t}^{2}$ & Adj. $\mathbf{R}^{2}$ & & Intercept & $\sigma_{\mathrm{t}}$ & $\Delta \sigma_{\mathrm{t}}$ & $\mu_{\mathrm{t}-1}$ & $\varepsilon_{\sigma t}$ & Adj. $R^{2}$ \\
\hline$\mu_{\mathrm{t}}$ & $\begin{array}{c}-0.05 \\
(-13.70)\end{array}$ & $\begin{array}{c}0.16 \\
(8.00)\end{array}$ & & & & $20.34 \%$ & $\mu_{\mathrm{t}}$ & $\begin{array}{c}-0.06 \\
(-13.22)\end{array}$ & $\begin{array}{c}0.09 \\
(5.50)\end{array}$ & & & & $21.60 \%$ \\
\hline$\mu_{\mathrm{t}}$ & $\begin{array}{c}0.00 \\
(-2.30)\end{array}$ & $\begin{array}{c}0.02 \\
(3.43)\end{array}$ & & $\begin{array}{c}0.97 \\
(66.81)\end{array}$ & & $97.20 \%$ & $\mu_{\mathrm{t}}$ & $\begin{array}{c}0.00 \\
(-2.46)\end{array}$ & $\begin{array}{c}0.01 \\
(2.66)\end{array}$ & & $\begin{array}{c}0.97 \\
(65.10)\end{array}$ & & $97.17 \%$ \\
\hline$\mu_{\mathrm{t}}$ & $\begin{array}{c}0.00 \\
(-0.23)\end{array}$ & & $\begin{array}{c}0.01 \\
(1.31)\end{array}$ & $\begin{array}{c}0.99 \\
(66.98)\end{array}$ & & $97.09 \%$ & $\mu_{\mathrm{t}}$ & $\begin{array}{c}0.00 \\
(-0.25)\end{array}$ & & $\begin{array}{c}0.00 \\
(1.01)\end{array}$ & $\begin{array}{c}0.99 \\
(66.32)\end{array}$ & & $97.06 \%$ \\
\hline$\Delta \mu_{\mathrm{t}}$ & $\begin{array}{c}0.00 \\
(2.05)\end{array}$ & & $\begin{array}{c}0.01 \\
(1.40)\end{array}$ & & & $1.45 \%$ & $\Delta \mu_{\mathrm{t}}$ & $\begin{array}{c}0.00 \\
(2.03)\end{array}$ & & $\begin{array}{c}0.00 \\
(1.07)\end{array}$ & & & $0.49 \%$ \\
\hline$\varepsilon_{\mu \mathrm{t}}$ & $\begin{array}{c}0.00 \\
(0.00) \\
\end{array}$ & & & & $\begin{array}{c}0.02 \\
(2.03) \\
\end{array}$ & $3.38 \%$ & $\varepsilon_{\mu t}$ & $\begin{array}{c}0.00 \\
(0.00) \\
\end{array}$ & & & & $\begin{array}{c}0.01 \\
(1.55) \\
\end{array}$ & $1.97 \%$ \\
\hline \multicolumn{14}{|c|}{ PANEL 3. GERMANY } \\
\hline & Intercept & $\sigma_{t}^{2}$ & $\Delta \sigma_{t}^{2}$ & $\mu_{\mathrm{t}-1}$ & $\varepsilon_{\sigma t}^{2}$ & Adj. $R^{2}$ & & Intercept & $\sigma_{\mathrm{t}}$ & $\Delta \sigma_{\mathrm{t}}$ & $\mu_{\mathrm{t}-1}$ & $\varepsilon_{\sigma t}$ & Adj. $R^{2}$ \\
\hline$\mu_{\mathrm{t}}$ & $\begin{array}{c}-0.05 \\
(-15.62)\end{array}$ & $\begin{array}{c}0.12 \\
(6.59)\end{array}$ & & & & $22.43 \%$ & $\mu_{\mathrm{t}}$ & $\begin{array}{c}-0.06 \\
(-17.37)\end{array}$ & $\begin{array}{c}0.07 \\
(4.33)\end{array}$ & & & & $23.89 \%$ \\
\hline$\mu_{\mathrm{t}}$ & $\begin{array}{c}0.00 \\
(-1.52)\end{array}$ & $\begin{array}{c}0.01 \\
(2.35)\end{array}$ & & $\begin{array}{c}0.97 \\
(46.78)\end{array}$ & & $95.73 \%$ & $\mu_{\mathrm{t}}$ & $\begin{array}{c}0.00 \\
(-1.52)\end{array}$ & $\begin{array}{c}0.01 \\
(1.84)\end{array}$ & & $\begin{array}{c}0.97 \\
(45.40)\end{array}$ & & $95.66 \%$ \\
\hline$\mu_{\mathrm{t}}$ & $\begin{array}{c}0.00 \\
(0.15)\end{array}$ & & $\begin{array}{c}0.00 \\
(0.71)\end{array}$ & $\begin{array}{c}0.99 \\
(49.74)\end{array}$ & & $95.53 \%$ & $\mu_{\mathrm{t}}$ & $\begin{array}{c}0.00 \\
(0.13)\end{array}$ & & $\begin{array}{c}0.00 \\
(0.61)\end{array}$ & $\begin{array}{c}0.99 \\
(50.02)\end{array}$ & & $95.53 \%$ \\
\hline$\Delta \mu_{\mathrm{t}}$ & $\begin{array}{c}0.00 \\
(1.62)\end{array}$ & & $\begin{array}{c}0.00 \\
(0.73)\end{array}$ & & & $-0.13 \%$ & $\Delta \mu_{\mathrm{t}}$ & $\begin{array}{c}0.00 \\
(1.62)\end{array}$ & & $\begin{array}{c}0.00 \\
(0.62)\end{array}$ & & & $-0.31 \%$ \\
\hline$\varepsilon_{\mu \mathrm{t}}$ & $\begin{array}{c}0.00 \\
(0.00) \\
\end{array}$ & & & & $\begin{array}{c}0.01 \\
(1.41) \\
\end{array}$ & $1.39 \%$ & $\varepsilon_{\mu \mathrm{t}}$ & $\begin{array}{c}0.00 \\
(0.00) \\
\end{array}$ & & & & $\begin{array}{c}0.00 \\
(1.08) \\
\end{array}$ & $0.59 \%$ \\
\hline \multicolumn{14}{|c|}{ PANEL 4. ITALY } \\
\hline & Intercept & $\sigma_{t}^{2}$ & $\Delta \sigma_{t}^{2}$ & $\mu_{\mathrm{t}-1}$ & $\varepsilon_{\sigma t}^{2}$ & Adj. $\mathrm{R}^{2}$ & & Intercept & $\sigma_{\mathrm{t}}$ & $\Delta \sigma_{\mathrm{t}}$ & $\mu_{\mathrm{t}-1}$ & $\varepsilon_{\sigma t}$ & Adj. $R^{2}$ \\
\hline$\mu_{\mathrm{t}}$ & $\begin{array}{c}-0.07 \\
(-7.25)\end{array}$ & $\begin{array}{c}0.21 \\
(2.41)\end{array}$ & & & & $5.57 \%$ & $\mu_{\mathrm{t}}$ & $\begin{array}{c}-0.09 \\
(-6.06)\end{array}$ & $\begin{array}{c}0.10 \\
(1.93)\end{array}$ & & & & $4.53 \%$ \\
\hline$\mu_{\mathrm{t}}$ & $\begin{array}{c}0.00 \\
(0.09)\end{array}$ & $\begin{array}{c}0.00 \\
(-0.26)\end{array}$ & & $\begin{array}{c}0.99 \\
(65.18)\end{array}$ & & $96.66 \%$ & $\mu_{\mathrm{t}}$ & $\begin{array}{c}0.00 \\
(0.29)\end{array}$ & $\begin{array}{c}0.00 \\
(-0.40)\end{array}$ & & $\begin{array}{c}0.99 \\
(65.63)\end{array}$ & & $96.66 \%$ \\
\hline$\mu_{\mathrm{t}}$ & $\begin{array}{c}0.00 \\
(-0.10)\end{array}$ & & $\begin{array}{c}0.00 \\
(-0.04)\end{array}$ & $\begin{array}{c}0.99 \\
(67.73)\end{array}$ & & $96.66 \%$ & $\mu_{\mathrm{t}}$ & $\begin{array}{c}0.00 \\
(-0.10)\end{array}$ & & $\begin{array}{c}0.00 \\
(0.17)\end{array}$ & $\begin{array}{c}0.99 \\
(67.95)\end{array}$ & & $96.66 \%$ \\
\hline$\Delta \mu_{\mathrm{t}}$ & $\begin{array}{c}0.00 \\
(1.82)\end{array}$ & & $\begin{array}{c}0.00 \\
(-0.04)\end{array}$ & & & $-0.68 \%$ & $\Delta \mu_{\mathrm{t}}$ & $\begin{array}{c}0.00 \\
(1.83)\end{array}$ & & $\begin{array}{c}0.00 \\
(0.17)\end{array}$ & & & $-0.66 \%$ \\
\hline$\varepsilon_{\mu t}$ & $\begin{array}{c}0.00 \\
(0.00)\end{array}$ & & & & $\begin{array}{c}0.00 \\
(-0.15) \\
\end{array}$ & $-0.67 \%$ & $\varepsilon_{\mu \mathrm{t}}$ & $\begin{array}{c}0.00 \\
(0.00) \\
\end{array}$ & & & & $\begin{array}{c}0.00 \\
(-0.06)\end{array}$ & $-0.68 \%$ \\
\hline
\end{tabular}




\begin{tabular}{|c|c|c|c|c|c|c|c|c|c|c|c|c|c|}
\hline \multicolumn{14}{|c|}{ PANEL 5. JAPAN } \\
\hline & Intercept & $\sigma_{t}^{2}$ & $\Delta \sigma_{t}^{2}$ & $\mu_{\mathrm{t}-1}$ & $\varepsilon_{\sigma t}^{2}$ & Adj. $\mathrm{R}^{2}$ & & Intercept & $\sigma_{\mathrm{t}}$ & $\Delta \sigma_{\mathrm{t}}$ & $\mu_{\mathrm{t}-1}$ & $\varepsilon_{\sigma t}$ & Adj. $R^{2}$ \\
\hline$\mu_{\mathrm{t}}$ & $\begin{array}{c}-0.02 \\
(-5.43)\end{array}$ & $\begin{array}{c}-0.02 \\
(-0.31)\end{array}$ & & & & $-0.47 \%$ & $\mu_{\mathrm{t}}$ & $\begin{array}{c}-0.03 \\
(-5.20)\end{array}$ & $\begin{array}{c}0.01 \\
(0.28)\end{array}$ & & & & $-0.51 \%$ \\
\hline$\mu_{\mathrm{t}}$ & $\begin{array}{c}0.00 \\
(0.08)\end{array}$ & $\begin{array}{c}0.00 \\
(0.93)\end{array}$ & & $\begin{array}{c}0.99 \\
(83.89)\end{array}$ & & $98.70 \%$ & $\mu_{\mathrm{t}}$ & $\begin{array}{c}0.00 \\
(-0.44)\end{array}$ & $\begin{array}{c}0.00 \\
(0.98)\end{array}$ & & $\begin{array}{c}0.99 \\
(83.54)\end{array}$ & & $98.70 \%$ \\
\hline$\mu_{\mathrm{t}}$ & $\begin{array}{c}0.00 \\
(0.53)\end{array}$ & & $\begin{array}{c}0.00 \\
(0.51)\end{array}$ & $\begin{array}{c}0.99 \\
(83.06)\end{array}$ & & $98.69 \%$ & $\mu_{\mathrm{t}}$ & $\begin{array}{c}0.00 \\
(0.53)\end{array}$ & & $\begin{array}{c}0.00 \\
(0.39)\end{array}$ & $\begin{array}{c}0.99 \\
(83.29)\end{array}$ & & $98.69 \%$ \\
\hline$\Delta \mu_{\mathrm{t}}$ & $\begin{array}{c}0.00 \\
(1.95)\end{array}$ & & $\begin{array}{c}0.00 \\
(0.52)\end{array}$ & & & $-0.51 \%$ & $\Delta \mu_{\mathrm{t}}$ & $\begin{array}{c}0.00 \\
(1.95)\end{array}$ & & $\begin{array}{c}0.00 \\
(0.41)\end{array}$ & & & $-0.54 \%$ \\
\hline$\varepsilon_{\mu \mathrm{t}}$ & $\begin{array}{c}0.00 \\
(0.00) \\
\end{array}$ & & & & $\begin{array}{c}0.00 \\
(0.84) \\
\end{array}$ & $-0.31 \%$ & $\varepsilon_{\mu \mathrm{t}}$ & $\begin{array}{c}0.00 \\
(0.00) \\
\end{array}$ & & & & $\begin{array}{c}0.00 \\
(0.80) \\
\end{array}$ & $-0.25 \%$ \\
\hline \multicolumn{14}{|c|}{ PANEL 6. UNITED KINGDOM } \\
\hline & Intercept & $\sigma_{t}^{2}$ & $\Delta \sigma_{\mathrm{t}}^{2}$ & $\mu_{\mathrm{t}-1}$ & $\varepsilon_{\sigma t}^{2}$ & Adj. $\mathbf{R}^{2}$ & & Intercept & $\sigma_{\mathrm{t}}$ & $\Delta \sigma_{\mathrm{t}}$ & $\mu_{\mathrm{t}-1}$ & $\varepsilon_{\sigma t}$ & $\operatorname{Adj} . R^{2}$ \\
\hline$\mu_{\mathrm{t}}$ & $\begin{array}{c}-0.08 \\
(-13.84)\end{array}$ & $\begin{array}{c}0.27 \\
(5.05)\end{array}$ & & & & $13.74 \%$ & $\mu_{\mathrm{t}}$ & $\begin{array}{c}-0.09 \\
(-15.68)\end{array}$ & $\begin{array}{c}0.13 \\
(6.74)\end{array}$ & & & & $17.02 \%$ \\
\hline$\mu_{\mathrm{t}}$ & $\begin{array}{c}0.00 \\
(-1.43)\end{array}$ & $\begin{array}{c}0.02 \\
(2.69)\end{array}$ & & $\begin{array}{c}0.98 \\
(66.56)\end{array}$ & & $97.93 \%$ & $\mu_{\mathrm{t}}$ & $\begin{array}{c}0.00 \\
(-1.61)\end{array}$ & $\begin{array}{c}0.01 \\
(2.08)\end{array}$ & & $\begin{array}{c}0.98 \\
(64.62)\end{array}$ & & $97.93 \%$ \\
\hline$\mu_{\mathrm{t}}$ & $\begin{array}{c}0.00 \\
(-0.57)\end{array}$ & & $\begin{array}{c}0.01 \\
(0.83)\end{array}$ & $\begin{array}{c}0.99 \\
(70.67)\end{array}$ & & $97.90 \%$ & $\mu_{\mathrm{t}}$ & $\begin{array}{c}0.00 \\
(-0.58)\end{array}$ & & $\begin{array}{c}0.00 \\
(0.62)\end{array}$ & $\begin{array}{c}0.99 \\
(70.70)\end{array}$ & & $97.89 \%$ \\
\hline$\Delta \mu_{\mathrm{t}}$ & $\begin{array}{c}0.00 \\
(1.61)\end{array}$ & & $\begin{array}{c}0.01 \\
(0.87)\end{array}$ & & & $-0.39 \%$ & $\Delta \mu_{\mathrm{t}}$ & $\begin{array}{c}0.00 \\
(1.61)\end{array}$ & & $\begin{array}{c}0.00 \\
(0.64)\end{array}$ & & & $-0.45 \%$ \\
\hline$\varepsilon_{\mu \mathrm{t}}$ & $\begin{array}{c}0.00 \\
(0.00) \\
\end{array}$ & & & & $\begin{array}{c}0.01 \\
(1.68) \\
\end{array}$ & $0.32 \%$ & $\varepsilon_{\mu \mathrm{t}}$ & $\begin{array}{c}0.00 \\
(0.00) \\
\end{array}$ & & & & $\begin{array}{c}0.01 \\
(1.23) \\
\end{array}$ & $0.11 \%$ \\
\hline \multicolumn{14}{|c|}{ PANEL 7. UNITED STATES } \\
\hline & Intercept & $\sigma_{t}^{2}$ & $\Delta \sigma_{t}^{2}$ & $\mu_{\mathrm{t}-1}$ & $\varepsilon_{\sigma t}^{2}$ & Adj. $\mathrm{R}^{2}$ & & Intercept & $\sigma_{\mathrm{t}}$ & $\Delta \sigma_{\mathrm{t}}$ & $\mu_{\mathrm{t}-1}$ & $\varepsilon_{\sigma t}$ & Adj. $R^{2}$ \\
\hline$\mu_{\mathrm{t}}$ & $\begin{array}{c}-0.05 \\
(-13.82)\end{array}$ & $\begin{array}{c}0.05 \\
(1.11)\end{array}$ & & & & $1.19 \%$ & $\mu_{\mathrm{t}}$ & $\begin{array}{c}-0.06 \\
(-10.46)\end{array}$ & $\begin{array}{c}0.04 \\
(1.46)\end{array}$ & & & & $2.37 \%$ \\
\hline$\mu_{\mathrm{t}}$ & $\begin{array}{c}0.00 \\
(-2.07)\end{array}$ & $\begin{array}{c}0.02 \\
(5.88)\end{array}$ & & $\begin{array}{c}0.97 \\
(52.39)\end{array}$ & & $95.41 \%$ & $\mu_{\mathrm{t}}$ & $\begin{array}{c}0.00 \\
(-2.25)\end{array}$ & $\begin{array}{c}0.01 \\
(1.99)\end{array}$ & & $\begin{array}{c}0.97 \\
(51.41)\end{array}$ & & $95.28 \%$ \\
\hline$\mu_{\mathrm{t}}$ & $\begin{array}{c}0.00 \\
(-1.18)\end{array}$ & & $\begin{array}{c}0.01 \\
(1.75)\end{array}$ & $\begin{array}{c}0.97 \\
(51.46)\end{array}$ & & $95.24 \%$ & $\mu_{\mathrm{t}}$ & $\begin{array}{c}0.00 \\
(-1.20)\end{array}$ & & $\begin{array}{c}0.01 \\
(1.08)\end{array}$ & $\begin{array}{c}0.97 \\
(51.20)\end{array}$ & & $95.19 \%$ \\
\hline$\Delta \mu_{\mathrm{t}}$ & $\begin{array}{c}0.00 \\
(1.10)\end{array}$ & & $\begin{array}{c}0.01 \\
(1.77)\end{array}$ & & & $1.62 \%$ & $\Delta \mu_{\mathrm{t}}$ & $\begin{array}{c}0.00 \\
(1.10)\end{array}$ & & $\begin{array}{c}0.01 \\
(1.11)\end{array}$ & & & $0.60 \%$ \\
\hline$\varepsilon_{\mu \mathrm{t}}$ & $\begin{array}{c}0.00 \\
(0.00) \\
\end{array}$ & & & & $\begin{array}{c}0.02 \\
(5.92) \\
\end{array}$ & $4.56 \%$ & $\varepsilon_{\mu t}$ & $\begin{array}{c}0.00 \\
(0.00)\end{array}$ & & & & $\begin{array}{c}0.01 \\
(1.77) \\
\end{array}$ & $1.88 \%$ \\
\hline
\end{tabular}




\section{Appendix}

Proofs of equations (9) and (5):

By iterating equation (8) forward, we obtain $E_{t}\left(r_{t+1+j}\right)=\alpha \frac{1-\beta^{j}}{1-\beta}+\beta^{j} \mu_{t}$. Equation (9) follows:

$$
\begin{aligned}
\sum_{j=0}^{\infty} \rho^{j} E_{t}\left(r_{t+1+j}\right) & =\sum_{j=0}^{\infty} \rho^{j}\left(\alpha \frac{1-\beta^{j}}{1-\beta}+\beta^{j} \mu_{t}\right) \\
& =\frac{\alpha}{1-\beta} \sum_{j=0}^{\infty} \rho^{j}\left(1-\beta^{j}\right)+\mu_{t} \sum_{j=0}^{\infty} \rho^{j} \beta^{j} \\
& =\frac{\alpha}{1-\beta} \sum_{j=0}^{\infty} \rho^{j}-\frac{\alpha}{1-\beta} \sum_{j=0}^{\infty} \rho^{j} \beta^{j}+\mu_{t} \sum_{j=0}^{\infty} \rho^{j} \beta^{j} \\
& =\frac{\alpha}{(1-\beta)(1-\rho)}+\left(\mu_{t}-\frac{\alpha}{1-\beta}\right) \frac{1}{1-\rho \beta} .
\end{aligned}
$$

To prove equation (5), we first note that $E_{t}\left(g_{t+k}\right)=\left(1-\delta^{k}\right) \frac{\gamma}{1-\delta}+\delta^{k} g_{t}, E_{t}\left(d_{t+k}\right)=d_{t}+\sum_{i=1}^{k} E_{t}\left(g_{t+i}\right)$, and $\sum_{j=0}^{\infty} j \rho^{j}=\frac{\rho}{(1-\rho)^{2}}$. Equation (5) then follows easily in a manner similar to equation (9).

\section{Proof of equation (14):}

Using a first-order Taylor approximation to $r_{t+1}=\log \left(P_{t+1}+D_{t+1}\right)-\log \left(P_{t}\right)$, Campbell and Shiller (1988) show that

$$
r_{t+1} \approx k+\rho p_{t+1}+(1-\rho) d_{t+1}-p_{t} .
$$

Substitute for $p_{t+1}$ from equation (10) and pool together all terms known at time $t$ :

$$
r_{t+1} \approx k_{t}^{\prime}+d_{t+1}+g_{t+1} \frac{\delta \rho}{(1-\rho \delta)}-\mu_{t+1} \frac{\rho}{1-\rho \beta} .
$$

The return variance can be approximated by taking the variance of the right hand side:

$$
\begin{aligned}
\operatorname{Var}_{t}\left(r_{t+1}\right)= & \sigma_{v, t+1}^{2}+\frac{\delta^{2} \rho^{2}}{(1-\rho \delta)^{2}} \sigma_{v, t+1}^{2}+\frac{\rho^{2}}{(1-\rho \beta)^{2}} \sigma_{u}^{2} \\
& +2 \frac{\rho \delta}{(1-\rho \delta)} \sigma_{v, t+1}^{2}-2 \frac{\rho}{1-\rho \beta} \sigma_{u v}-2 \frac{\rho^{2} \delta}{(1-\rho \delta)(1-\rho \beta)} \sigma_{u v} \\
= & \frac{1}{(1-\rho \delta)^{2}} \sigma_{v, t+1}^{2}+\frac{\rho^{2}}{(1-\rho \beta)^{2}} \sigma_{u}^{2}-\frac{2 \rho}{(1-\rho \delta)(1-\rho \beta)} \sigma_{u v}
\end{aligned}
$$

where $\sigma_{u v}$ is the covariance between $u_{t}$ and $v_{t}$. We assume that $\sigma_{u v}=0$, for simplicity, so that

$$
\operatorname{Var}_{t}\left(r_{t+1}\right)=\frac{1}{(1-\rho \delta)^{2}} \sigma_{v, t+1}^{2}+\frac{\rho^{2}}{(1-\rho \beta)^{2}} \sigma_{u}^{2}
$$

which proves equation (14). 


\section{REFERENCES}

Abel, Andrew B., 1988, "Stock prices under time-varying dividend risk: An exact solution in an infinite-horizon general equilibrium model," Journal of Monetary Economics 22, $375-393$.

Andersen, Torben G., Tim Bollerslev, Francis X. Diebold, and Paul Labys, 2003, "Modeling and forecasting realized volatility," Econometrica 71, 529-626.

Backus, David, and Allan W. Gregory, 1993, "Theoretical relations between risk premiums and conditional variances," Journal of Business and Economic Statistics 11, 177-185.

Baillie, Richard T., and Ramon P. DeGennaro, 1990, "Stock returns and volatility," Journal of Financial and Quantitative Analysis 25, 203-214.

Black, Fischer, 1976, "Studies of stock market volatility changes," 1976 Proceedings of the American Statistical Association, Business and Economic Statistics Section, 177-181.

Brandt, Michael W., and Qiang Kang, 2004, "On the Relationship Between the Conditional Mean and Volatility of Stock Returns: A Latent VAR Approach," Journal of Financial Economics 72, 217-257.

Brav, Alon, Reuven Lehavy, and Roni Michaely, 2003, "Using expectations to test asset pricing models," Financial Management, forthcoming.

Brealey, Richard A., and Stewart Myers, 2002, Principles of Corporate Finance, Seventh Edition, Irwin McGraw-Hill.

Campbell, John Y., 1987, "Stock returns and the term structure," Journal of Financial Economics 18, 373-399.

Campbell, John Y., 1993, Intertemporal asset pricing without consumption data, American Economic Review 83, 487-512.

Campbell, John Y., and Robert J. Shiller, 1988, "The dividend-price ratio and expectations of future dividends and discount factors," Review of Financial Studies 1, 195-228.

Campbell, John Y., and Ludger Hentschel, 1992, "No news is good news: An asymmetric model of changing volatility in stock returns," Journal of Financial Economics 31, 281331.

Campbell, John Y., and John Ammer, 1993, "What moves the stock and bond markets? A variance decomposition for long-term asset returns," Journal of Finance 48, 3-37.

Campbell, John Y., and Luis M. Viceira, 2002, Strategic Asset Allocation: Portfolio Choice for Long-Term Investors, Oxford University Press.

Chan, Louis K. C., Andrew Karolyi, and René M. Stulz, 1992, "Global financial markets and the risk premium," Journal of Financial Economics 32, 137-167. 
Chan, Louis K. C., Jason Karceski, and Josef Lakonishok, 2003, "The level and persistence of growth rates," Journal of Finance 58, 643-684.

Claus, James, and Jacob Thomas, 2001, "Equity premia as low as three percent? Evidence from analysts' earnings forecasts for domestic and international stock markets," Journal of Finance 56, 1629-1666.

De Santis, Giorgio, and Selahattin Imrohoroglu, 1997, "Stock returns and volatility in emerging financial markets," Journal of International Money and Finance 16, 561-579.

Elton, Edwin J., 1999, "Expected return, realized return, and asset pricing tests", Journal of Finance 54, 1199-1220.

Fama, Eugene F., and Kenneth R. French, 2002, "The equity premium", Journal of Finance $57,637-659$.

French, Kenneth R., G. William Schwert, and Robert F. Stambaugh, 1987, "Expected stock returns and variance," Journal of Financial Economics 19, 3-29.

Friend, Irwin, Randolph Westerfield, and Michael Granito, 1978, "New evidence on the capital asset pricing model," Journal of Finance 33, 903-917.

Gebhardt, William R., Charles M. C. Lee, and Bhaskaran Swaminathan, 2001, "Toward an implied cost of capital," Journal of Accounting Research 39, 135-176.

Ghysels, Eric, Pedro Santa-Clara, and Rossen Valkanov, 2005, "There is a risk-return tradeoff after all," Journal of Financial Economics 76, 509-548.

Glosten, Lawrence R., Ravi Jagannathan, and David E. Runkle, 1993, "On the relation between the expected value and the variance of the nominal excess return on stocks," Journal of Finance 48, 1779-1801.

Guo, Hui, and Robert F. Whitelaw, 2005, "Uncovering the risk-return relation in the stock market," Journal of Finance, forthcoming.

Harvey, Campbell R., 2001, "The specification of conditional expectations," Journal of Empirical Finance 8, 573-637.

Kaplan, Steven N., and Richard S. Ruback, 1995, "The valuation of cash flow forecasts: An empirical analysis," Journal of Finance 50, 1059-1093.

Lee, Charles M. C., David Ng, and Bhaskaran Swaminathan, 2003, "The cross-section of international cost of capital," Working paper, Cornell University.

Lettau, Martin, and Sydney C. Ludvigson, 2003, "Measuring and modeling variation in the risk-return tradeoff," in Yacine Ait-Sahalia and Lars P. Hansen, eds.: Handbook of Financial Econometrics. 
Lundblad, Christian, 2005, "The risk return tradeoff in the long-run: 1836-2003," Working paper, Indiana University.

Merton, Robert C., 1973, "An intertemporal asset pricing model," Econometrica 41, 867-888.

Merton, Robert C., 1980, "On estimating the expected return on the market: An exploratory investigation," Journal of Financial Economics 8, 323-361.

Nelson, Daniel B., 1991, "Conditional heteroskedasticity in asset returns: A new approach," Econometrica 59, 347-370.

Pástor, Ľuboš, and Robert F. Stambaugh, 2001, "The equity premium and structural breaks", Journal of Finance 56, 1207-1239.

Scruggs, John T., 1998, "Resolving the puzzling intertemporal relation between the market risk premium and conditional market variance: A two-factor approach," Journal of Finance 53, 575-603.

Turner, Christopher M., Richard Startz, and Charles R. Nelson, 1989, "A Markov model of heteroskedasticity, risk, and learning in the stock market," Journal of Financial Economics 25, 3-22.

Veronesi, Pietro, 2000, "How does information quality affect stock returns?," Journal of Finance 55, 807-837.

Wang, Leping, 2004, "On the intertemporal risk-return relation: A Bayesian model comparison perspective," Working paper, Wharton.

Whitelaw, Robert F., 1994, "Time variations and covariations in the expectation and volatility of stock market returns," Journal of Finance 49, 515-541.

Whitelaw, Robert F., 2000, "Stock market risk and return: An equilibrium approach", Review of Financial Studies 13, 521-547. 